\title{
The recent weathering of uraninite from the Červená vein, Jáchymov (Czech Republic): a fingerprint of the primary mineralization geochemistry onto the alteration association
}

\author{
In memory of Dr. Jan Hloušek (10 March 1950-27 April 2014)
}

\author{
Jakub Plášil1, Jiří Sejkora², Radek Škoda³ ${ }^{3}$ Pavel Škácha ${ }^{4,5}$ \\ ${ }^{1}$ Institute of Physics, Academy of Sciences of the Czech Republic v.v.i, Na Slovance 2, 18221 Prague 8, Czech Republic; plasil@fzu.cz \\ ${ }^{2}$ Department of Mineralogy and Petrology, National Museum, Cirkusová 1740, 19300 Prague 9, Czech Republic \\ ${ }^{3}$ Department of Geological Sciences, Faculty of Science, Masaryk University, Kotlářská 2, 61137 Brno, Czech Republic \\ ${ }^{4}$ Institute of Geochemistry, Mineralogy and Mineral Resources, Faculty of Science, Charles University in Prague, Albertov 6, 12843 \\ Prague 2, Czech Republic \\ ${ }^{5}$ Mining Museum Př́bram, náměstí Hynka Kličky 293, 26101 Př́bram VI, Czech Republic \\ *Corresponding author
}

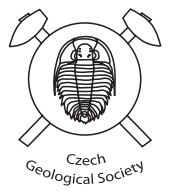

\begin{abstract}
Uraninite and the supergene minerals from the Červená hydrothermal uranium vein (Jáchymov ore district, Czech Republic) were studied. These supergene minerals represent alteration products of the joint weathering of uraninite and hypogene sulfide minerals, connected to the acid-mine drainage (AMD) systems. The complex geochemistry of the hypogene mineralization provided a unique environment for formation of chemically diverse supergene phases. Among other features, the weathering system is characterized by the high activity of $\mathrm{Cu}^{2+}$ and REE, which control the composition of the resulting supergene minerals: commonly occurring are $\mathrm{Cu}$-dominant uranyl sulfates of the zippeite group (pseudojohannite, Cu-rabejacite), Cu-dominant uranyl silicates (cuprosklodowksite) or Y- and REE-containing uranyl-sulfate mineral sejkoraite-(Y). The high activity of $\mathrm{Cu}^{2+}$ and $\mathrm{REE}$ is also reflected by the fact that both elements enter minerals, which are nominally $\mathrm{Cu}$ - or REE-free (marécottite, rabejacite, tyuyamunite, and compreignacite). The alteration association was evaluated with regard to the crystal-chemical properties of each mineral using the bond-valence approach, documenting distinct evolutionary trends during weathering.
\end{abstract}

Keywords: uraninite, supergene weathering, acid-mine drainage, mineral data, $X$-ray diffraction, bond-valence approach Received: 3 October 2013; accepted: 28 May 2014; handling editor: F. Laufek

The online version of this article (doi: 10.3190/jgeosci.171) contains supplementary electronic material.

\section{Introduction}

Studies on alteration of uraninite, ideally $\mathrm{UO}_{2}$, in oxidizing conditions, help us to better understand the processes such as dissolution, transport and retardation/immobilization of uranium and other elements in the environment. Uranyl-sulfates are typical products of uraninite alteration in the acidic oxidizing environment (Ondruš et al. 1997; Finch and Murakami 1999; Meisser et al. 2002; Brugger et al. 2003, 2006; Plášil et al. 2012a, b; Krivovichev and Plášil 2013; Plášil 2014). The sulfate-rich solutions, resulting from the decomposition of the primary sulfide minerals by descending oxidizing waters, are responsible for the migration of the uranyl ion $\left(\mathrm{UO}_{2}\right)^{2+}$ under the low pH conditions (Fernandes et al. 1995; Brugger et al. 2003, and references therein).

The studied association of supergene minerals from the Červená vein in the Jáchymov (St. Joachimsthal) ore district represents a typical alteration association of the recent origin, resulting from the weathering and decomposition of the primary uranium minerals, occurring together with copper sulfides, in the old mining workings. This paper presents results of the detailed mineralogical study concerned with the nature and genesis of this mineral association.

\section{Occurrence}

The Jáchymov (St. Joachimsthal) ore district, located in the vicinity of the namesake town in western Bohemia, Czech Republic, is a classic example of $\mathrm{Ag}+\mathrm{As}$ $+\mathrm{Co}+\mathrm{Ni}+\mathrm{Bi}+\mathrm{U}$ vein-type hydrothermal mineralization. The ore veins cut a complex of medium-grade metasedimentary rocks of Cambrian to Ordovician age, in the contact aureole of a Variscan granite pluton. The majority of ore minerals were deposited in Variscan times from mesothermal fluids (Ondruš et al. 2003a, b). Primary and supergene mineralization in this district resulted in extraordinarily rich associations; more than 420 mineral species have been described to date (Ondruš et al. 1997, 2003b, c; Plášil et al. 2010, 
2011a, b, 2012b, 2013a; Sejkora et al. 2010a-c; Tvrdý and Plášil 2010).

The studied site is located at the Červená vein, (known as "Roter Gang" to the German miners), at the level of the Daniel adit (303 m under the surface) near the Rovnost shaft ("Werner Schacht") (50²2'18.315"N, $12^{\circ} 53^{\prime} 32.784$ "E) in the western part of Jáchymov ore district. The vein cuts the Jáchymov-series of metamorphic rocks. In the immediate vicinity of the studied mineralization, a Tertiary basalt dyke intersects the ore vein together with the few fault-zones. The samples described in this study were found on the foot-wall of an old mining adit, partly lying directly on the surface and partly distributed in a material of a thickness up to $10 \mathrm{~cm}$. The material comes from the ore-lens located on the hanging-wall. This ore-lens consisted of the partly altered primary mineralization, namely of uraninite, chalcopyrite and tennantite. The lens was probably mined during the prospecting works in 1950 ' $\mathrm{s}$, when the small portion of the uraninite bearing specimens and fine-grained dust were buried on the footwall of the adit. However this area, probably this accumulation too, is known for longer time; the detailed description of a rich uraninite accumulation in association with copper ores was reported by Štěp and Becke (1904). The area itself was used for radon water storage for spa in Jáchymov, known as Štěp's springs (Trvala 1962), since the leaking water from the vein structures and enriched in U-ore deposited on the footwalls provided a very high activity (of about 2884 Mache units $=38.8 \mathrm{kBq} / \mathrm{l})$.

\section{Experimental}

\subsection{Microphotography and scanning electron microscopy}

The surface morphology of the samples was studied using the optical microscope Nikon SMZ1500 in combination with the digital camera Nikon DXM1200F (National Museum, Prague) and optical microscope Zeiss Stemi2000. Nikon microscope was also used for microphotography in incandescent light. The details of surface morphology of gold-coated samples were studied with the scanning electron microscopes (SEM) Jeol JSM-6380 (Institute of Geology and Palaeontology, Charles University in Prague) and Hitachi 3700N (National Museum, Prague) both in secondary and backscattered electron modes.

\subsection{Chemical composition}

Chemical composition of studied minerals was obtained using an electron microprobe Cameca SX100 (Joint
Laboratory of the Masaryk University and Czech Geological Survey, Brno). Wavelength dispersive mode and following conditions were used. Uraninite: accelerating voltage of $15 \mathrm{kV}$, current of $60 \mathrm{nA}, 5 \mu \mathrm{m}$ beam diameter; analytic lines and standards: $\mathrm{K}_{\alpha}$ lines: $\mathrm{Na}$ (albite), $\mathrm{Si}$ (sanidine), $\mathrm{P}\left(\mathrm{LaPO}_{4}\right), \mathrm{Ca}$ (fluorapatite), $\mathrm{Fe}$ (almandine), $\mathrm{S}\left(\mathrm{SrSO}_{4}\right), \mathrm{F}$ (topaz); $\mathrm{L}_{\alpha}$ lines: $\mathrm{Y}\left(\mathrm{YPO}_{4}\right), \mathrm{Sr}\left(\mathrm{SrSO}_{4}\right), \mathrm{La}$ $\left(\mathrm{LaPO}_{4}\right), \mathrm{Ce}\left(\mathrm{CePO}_{4}\right)$, Dy $\left(\mathrm{DyPO}_{4}\right)$, Er $\left(\mathrm{ErPO}_{4}\right)$, As (lammerite); $\mathrm{L}_{\beta}$ lines: $\operatorname{Pr}\left(\mathrm{PrPO}_{4}\right), \mathrm{Nd}\left(\mathrm{NdPO}_{4}\right), \mathrm{Sm}\left(\mathrm{SmPO}_{4}\right)$, $\mathrm{Eu}\left(\mathrm{EuPO}_{4}\right), \mathrm{Gd}\left(\mathrm{GdPO}_{4}\right) ; \mathrm{M}_{\alpha}$ lines: Th $\left(\mathrm{CaTh}\left[\mathrm{PO}_{4}\right]_{2}\right)$, $\mathrm{Pb}$ (vanadinite); $\mathrm{M}_{\beta}$ lines: $\mathrm{U}$ (U). Sulfides: accelerating voltage of $25 \mathrm{kV}$, current of $20 \mathrm{nA}, 2 \mu \mathrm{m}$ beam diameter; analytic lines and standards: $\mathrm{K}_{\alpha}$ lines: $\mathrm{Zn}(\mathrm{ZnS}), \mathrm{Fe}, \mathrm{S}$ $\left(\mathrm{FeS}_{2}\right), \mathrm{Co}(\mathrm{Co}), \mathrm{Cu}(\mathrm{Cu}), \mathrm{Ni}$ (pararammelsbergite), $\mathrm{Mn}$ $(\mathrm{Mn}) ; \mathrm{L}_{\alpha}$ lines: $\mathrm{Ge}(\mathrm{Ge})$, In (InAs), $\mathrm{Ag}(\mathrm{Ag}) ; \mathrm{L}_{\beta}$ lines: As (pararammelsbergite), $\mathrm{Se}(\mathrm{PbSe}), \mathrm{Cd}(\mathrm{CdTe})$. Supergene phases: $15 \mathrm{kV}$ accelerating voltage, $2 \mathrm{nA}$ current, 15-20 $\mu \mathrm{m}$ beam diameter; analytic lines and standards: $\mathrm{K}_{\alpha}$ lines: $\mathrm{P}, \mathrm{Ca}$ (fluorapatite), $\mathrm{Na}$ (albite), $\mathrm{Fe}$ (almandine), $\mathrm{S}\left(\mathrm{SrSO}_{4}\right), \mathrm{V}\left(\mathrm{ScVO}_{4}\right), \mathrm{Mg}\left(\mathrm{MgAl}_{2} \mathrm{O}_{4}\right), \mathrm{Si}, \mathrm{Al}$, $\mathrm{K}$ (sanidine), $\mathrm{Zn}$ (gahnite), $\mathrm{Ni}\left(\mathrm{Ni}_{2} \mathrm{SiO}_{4}\right), \mathrm{Co}(\mathrm{Co}), \mathrm{Mn}$ (spessartine); $\mathrm{L}_{\alpha}$ lines: $\mathrm{Cu}$, As (lammerite); $\mathrm{L}_{\beta}$ lines: $\mathrm{Ba}$ (barite); $\mathrm{M}_{\alpha}$ lines: $\mathrm{Pb}$ (vanadinite), $\mathrm{U}$ (uranophane, ruthefordine). Peak counting times (CT) were 10-20 s for major elements, 40-60 s for minor to trace elements and counting time on background was $1 / 2 \mathrm{CT}$. The measured intensities were converted to element concentrations using the PAP program (Pouchou and Pichoir 1985). Elevated analytical totals of minerals containing a large amount of hydroxyl groups or crystal water are generally caused by water evaporation either under high-vacuum conditions or due to heating of the analyzed spot by the electron beam. Lower analytical totals for some samples are primarily a consequence of their porous nature or due to poorly polished surfaces of soft or cryptocrystalline minerals.

\subsubsection{CHIME dating of uraninite}

Assuming that all $\mathrm{Pb}$ in uraninite is radiogenic, i.e. resulting from the decay of $T h$ and $U$, the chemical age can be calculated as follows (Montel et al. 1996):

$\mathrm{Pb}=\frac{\mathrm{U}}{238.03} \times 0.99276 \times\left(\mathrm{e}^{\mathrm{\lambda} 238 \mathrm{t}}-1\right) \times 205.97+\frac{\mathrm{U}}{238.03}$

$\times 0.007196 \times\left(\mathrm{e}^{\lambda 235 \mathrm{t}}-1\right) \times 206.98+\frac{\mathrm{Th}}{232.04} \times\left(\mathrm{e}^{\mathrm{2} 232 \mathrm{t}}-1\right)$

$\times 207.97$

where $t$ is a time in years and $\lambda^{238}, \lambda^{235}$, and $\lambda^{232}$ are decay constants of the ${ }^{238} \mathrm{U},{ }^{235} \mathrm{U}$ and ${ }^{232} \mathrm{Th}$, respectively (Steiger and Jäger 1977).

The peak $\mathrm{CT}$ for $\mathrm{Pb}, \mathrm{U}$ and $\mathrm{Th}$ in uraninite analyses used for CHIME dating were 120, 60 and $60 \mathrm{~s}$, respectively. In order to obtain as precise $\mathrm{Pb}$ concentrations 
as possible, the measured contents of $\mathrm{Pb}$ were manually corrected for $\mathrm{Y} L_{\gamma 2}, \operatorname{Th} M_{\zeta 1}$ and $\mathrm{Th} M_{\zeta 2}$ overlaps on $\mathrm{Pb} M_{\alpha}$. Besides that, the analytical precision of $\mathrm{Pb}$ on the $M_{\alpha}$ line is higher than on $M_{\beta}$ line. We used a set of Th- and U-rich monazites of well characterized ages in range 320-970 Ma to verify the procedure and data.

\subsection{X-ray crystallography}

\subsubsection{Powder diffraction}

Powder X-ray diffraction data were acquired using several analytical devices.

1. The PANalytical X'Pert Pro diffractometer with a secondary monochromator, producing $\mathrm{Cu} K_{\alpha 1,2}$ radiation,

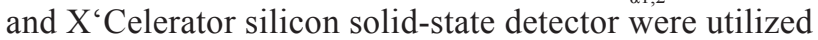
for data collection using the Bragg-Brentano geometry (Institute of Geochemistry, Mineralogy and Mineral Resources, Charles University in Prague).

2. The PANalytical Empyrean diffractometer equipped with a curved Göbel mirror, producing $\mathrm{Cu} K_{\alpha 1,2}$ radiation, and a PIXcel ${ }^{3 \mathrm{D}}$ solid-state detector were employed for measurements in the Debye-Scherrer geometry. Pulverized samples were loaded into $0.3 \mathrm{~mm}$ glass capillaries and rotated during the measurement in order to increase the counting statistics. The diffractometer was calibrated against a $\mathrm{LaB}_{6}$ (NIST) standard.

The unit-cell parameters from the powder data were refined by Celref program (Laugier and Bochu 2004) using the least-squares method. The theoretical powder patterns were calculated using PowderCell software (Kraus and Nolze 1996) based on the known structure data. The Le Bail fitting and Rietveld refinement were conducted using Jana2006 program (Petříček et al. 2006, 2014).

\subsubsection{Single-crystal diffraction}

For single-crystal X-ray diffraction experiments was utilized Oxford diffraction Gemini single-crystal diffractometer system equipped with an Atlas detector (using monochromatic $\mathrm{MoK}_{\alpha}$ radiation) and fiber-optics Mo-Enhance collimator. Unit-cell refinement and integration of the data (including background, Lorentz effect and polarization correction) and absorption correction (usually combined empirical and analytical correction, after Clark and Reid 1995) were done within CrysAlis RED (Agilent Technologies 2012). Crystal structures were solved from the three-dimensional intensity data by the charge-flipping algorithm implemented in the Superflip program (Palatinus and Chapuis 2007). Structure models were subsequently refined using the full-matrix least-squares algorithm (based on $F^{2}$ ) of the software JANA2006 (Petříček et al. 2006, 2014). The bond-valence analysis was done following procedures of Brown (1981, 2002).

\section{Results - minerals and their structural and chemical properties}

\subsection{Primary (hypogene) mineralization}

The primary minerals are represented by uraninite and abundant chalcopyrite in the quartz gangue. Besides these two minerals, pyrite, chalcocite and minor tennantite were found in the studied samples. Only rarely the native $\mathrm{Bi}$ and Ni-arsenides were found to form small veinlets. Primary uraninite and sulfides are strongly altered and replaced by younger, supergene phases.

$$
\begin{aligned}
& \text { 4.1.1. Uraninite, }\left(U_{1-x-y-z^{\prime}}^{4+} U_{x}^{6+} \operatorname{REE}_{y}^{3+} M_{z}^{2+}\right) \\
& O_{2+x-(0.5 y)-z}
\end{aligned}
$$

Uraninite is present as a residual phase. The centers of the residual aggregates have usually waxy luster, the color changing from blackish more towards grey. Uraninite is usually fine grained, forming intergrowths in the sulphide matrix, seldom occurring as massive aggregates. According to EMPA study, uraninite partially underwent coffinitization along cracks. This phase is characteristic of the less bright regions in BSE images (Fig. 1a). The cracks that are dark in BSE (on Fig. 1a) are probably newly formed due to the sub-recent oxidation-hydration weathering of uraninite, connected with volume changes (see Janeczek and Ewing 1992).

According to electron-microprobe study (Tab. 1), the chemical composition of uraninite is very varied. As the main constituents, $\mathrm{CaO}$ (up to 4.52 wt. \%), $\mathrm{PbO}$ (up to 1.90 wt. \%), $\mathrm{FeO}$ (up to 0.53 wt. \%) and the suite of $(\mathrm{Y}+\mathrm{REE})_{2} \mathrm{O}_{3}$ (up to $0.43 \mathrm{wt}$. \%) were found by EPMA, besides $\mathrm{UO}_{\mathrm{x}}$. The normalized REE pattern (using chondrite composition of McDonough and Sun 1995) shows relative enrichment in MREE and depletion in LREE and HREE (Fig. 2). Apart from assumed $\mathrm{O}^{2-}$, a small portion of other anions was detected, including $\mathrm{SO}_{4}^{2-}, \mathrm{PO}_{4}^{3-}$ and $\mathrm{AsO}_{4}{ }^{3-}$ (Tab. 1). An interesting issue arises concerning the amount of $\mathrm{U}^{6+}$ in the analyzed material, since no direct determination (e.g., using X-ray photoelectron spectroscopy) for the $\mathrm{UO}_{3}$ content is available. Taking all analyzed $\mathrm{UO}_{\mathrm{x}}$ as $\mathrm{UO}_{2}$, the empirical formula (based on the theoretical composition derived by Janeczek and Ewing 1992) (mean of 6 representative analyses; calculated on the basis of $\sum \mathrm{U}+M^{2+}+\mathrm{REE}=1$ apfu) is: $\left[\mathrm{U}_{0.74} \mathrm{Ca}_{0.18}(\mathrm{REE}+\mathrm{Y})_{0.02} \mathrm{~Pb}_{0.02}\left(\mathrm{Fe}_{0.02} \mathrm{Mn}_{0.01}\right)_{\Sigma 0.03}\right]_{\Sigma 0.99}\left\{\left(\mathrm{PO}_{4}\right)\right.$, $\left.\left(\mathrm{AsO}_{4}\right)\right\}_{\Sigma 0.01} \mathrm{O}_{1.76}$. 
(a)

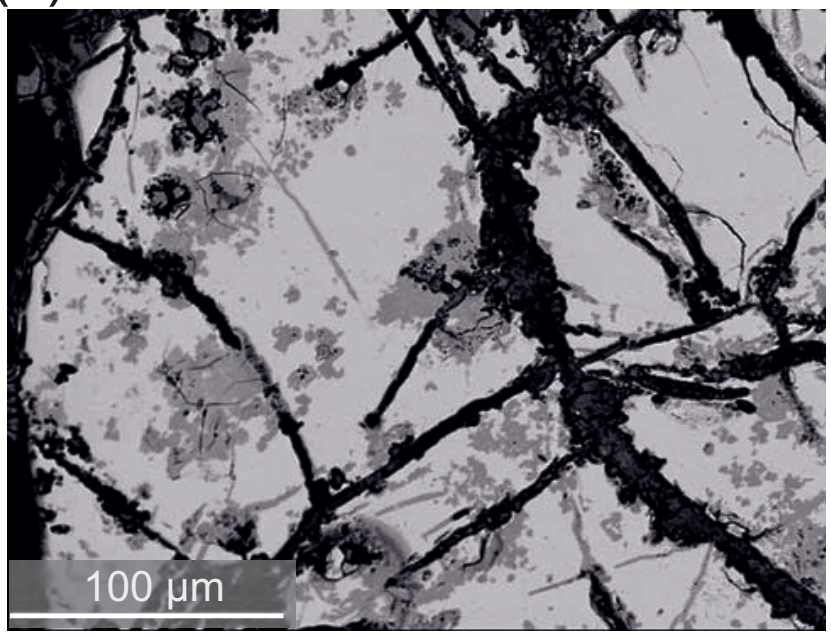

(c)

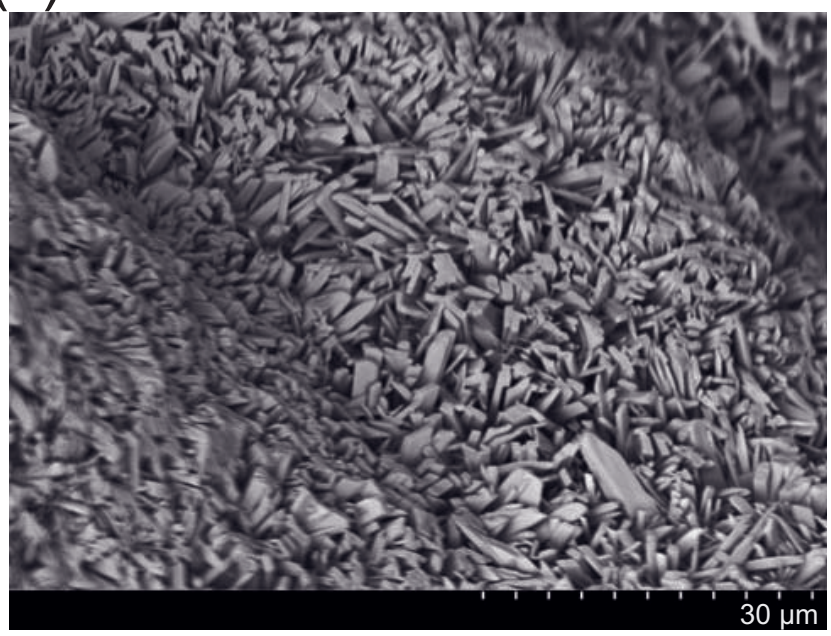

(e)

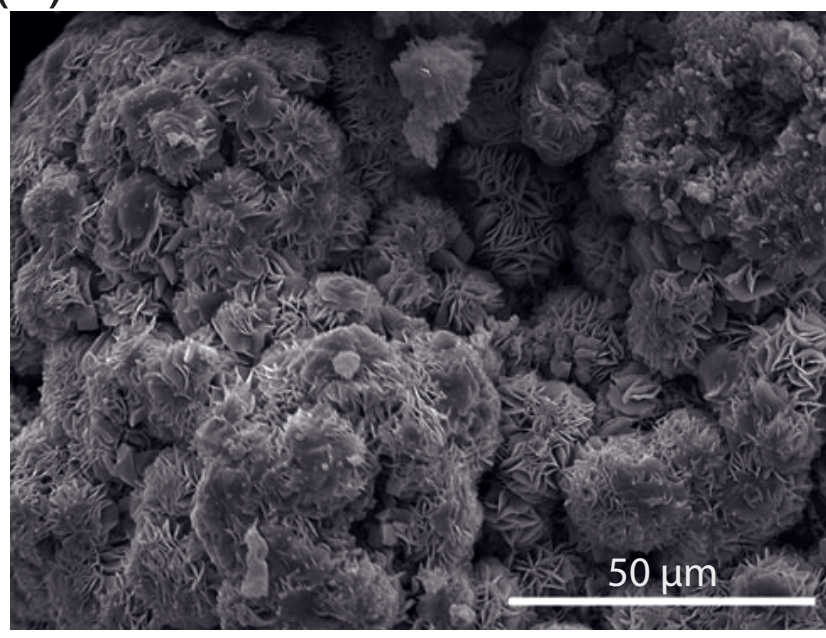

(b)

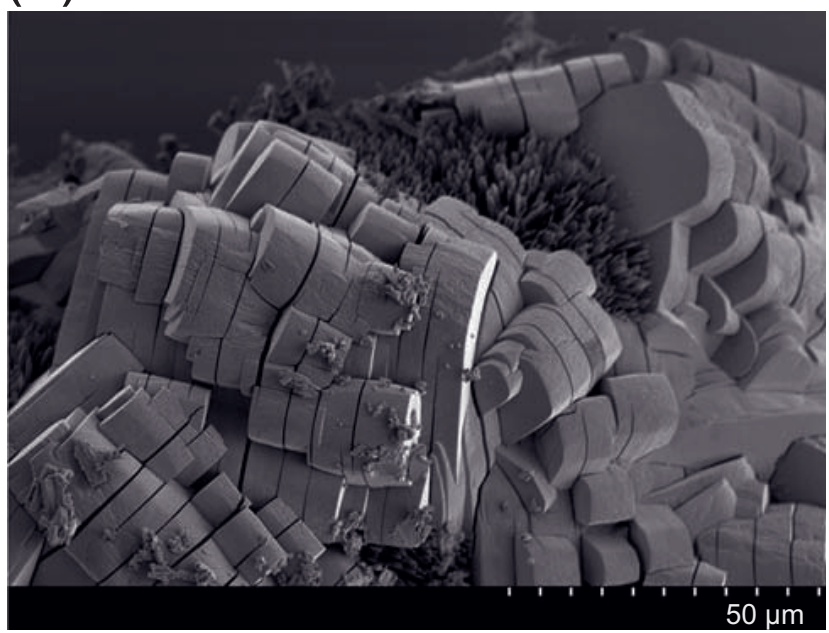

(d)

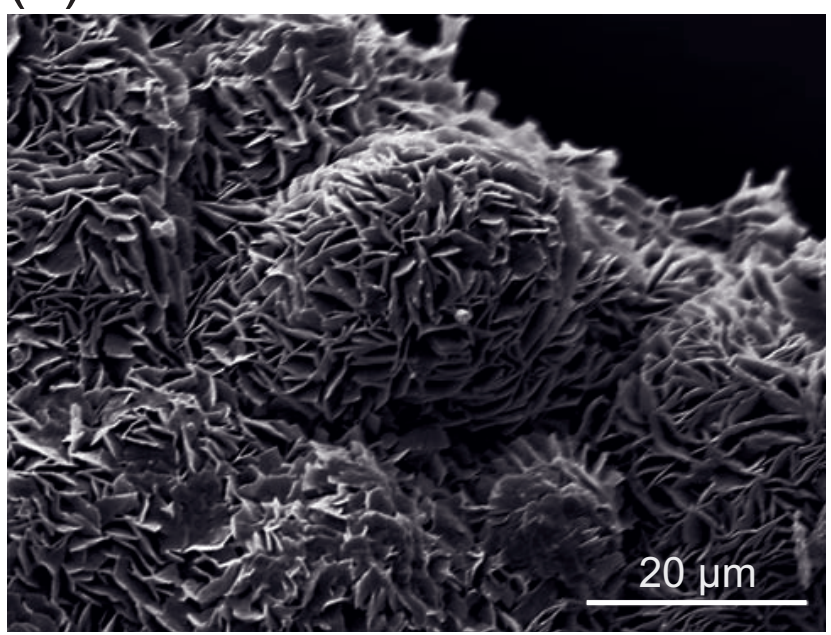

Fig. 1 Electron microscopy images. a - Uraninite (bright) and leached, coffinitized areas (greyish) with extension fractures filled by younger U-poor phases. BSE image (Cameca SX100). b - Crystals of compreignacite (type II) growing on cuprosklodowskite (needle-like crystals). SE image (Hitachi S-3700N). c - Crystalline aggregate of cuprosklodowskite composed of fine prismatic crystals. BSE COMP image (Hitachi S-3700N). d - Crystalline aggregates of soddyite composed of tiny platy crystals. SE image (Jeol JSM-6380). e - Microcrystalline aggregate of tyuyamunite. SE image (Jeol JSM-6380). 
Tab. 1 Chemical composition and CHIME age of uraninite from Červená vein

\begin{tabular}{|c|c|c|c|c|c|c|c|c|c|c|c|}
\hline \multicolumn{8}{|c|}{ Cores of aggregates } & \multicolumn{4}{|c|}{ Rims of aggregates } \\
\hline wt. $\%$ oxides & Mean & 1 & 2 & 3 & 4 & 5 & 6 & Mean & 1 & 2 & 3 \\
\hline $\mathrm{SO}_{3}$ & 0.20 & 0.23 & 0.20 & 0.21 & 0.18 & 0.17 & 0.20 & 0.52 & bdl & 0.29 & 1.26 \\
\hline $\mathrm{As}_{2} \mathrm{O}_{5}$ & 0.34 & 0.34 & 0.33 & 0.36 & 0.32 & 0.35 & 0.34 & 1.09 & 1.20 & 1.10 & 0.96 \\
\hline $\mathrm{P}_{2} \mathrm{O}_{5}$ & 0.12 & 0.13 & 0.12 & 0.11 & 0.15 & 0.11 & 0.10 & 0.11 & 0.12 & 0.12 & 0.10 \\
\hline $\mathrm{SiO}_{2}$ & bdl & bdl & bdl & bdl & bdl & bdl & bdl & 5.23 & 5.83 & 5.41 & 4.44 \\
\hline $\mathrm{UO}_{2}$ & 87.84 & 87.44 & 87.39 & 87.82 & 88.23 & 87.94 & 88.19 & 81.54 & 83.16 & 79.53 & 81.94 \\
\hline $\mathrm{Y}_{2} \mathrm{O}_{3}$ & 0.40 & 0.41 & 0.43 & 0.41 & 0.38 & 0.39 & 0.39 & 0.05 & 0.02 & 0.07 & 0.05 \\
\hline $\mathrm{Tm}_{2} \mathrm{O}_{3}$ & 0.56 & 0.54 & 0.57 & 0.52 & 0.56 & 0.57 & 0.62 & bdl & bdl & bdl & bdl \\
\hline $\mathrm{Lu}_{2} \mathrm{O}_{3}$ & 0.38 & 0.35 & 0.40 & 0.37 & 0.35 & 0.38 & 0.43 & bdl & bdl & bdl & bdl \\
\hline $\mathrm{Nd}_{2} \mathrm{O}_{3}$ & 0.29 & 0.25 & 0.29 & 0.29 & 0.28 & 0.32 & 0.32 & 0.12 & 0.10 & 0.12 & 0.13 \\
\hline $\mathrm{Sm}_{2} \mathrm{O}_{3}$ & 0.13 & 0.12 & 0.11 & 0.22 & 0.17 & 0.02 & 0.11 & bdl & bdl & bdl & bdl \\
\hline $\mathrm{Gd}_{2} \mathrm{O}_{3}$ & 0.23 & 0.24 & 0.22 & 0.23 & 0.25 & 0.19 & 0.23 & 0.08 & 0.04 & 0.12 & 0.08 \\
\hline $\mathrm{La}_{2} \mathrm{O}_{3}$ & 0.02 & bdl & bdl & bdl & 0.03 & 0.04 & 0.03 & bdl & bdl & bdl & bdl \\
\hline $\mathrm{Ce}_{2} \mathrm{O}_{3}$ & 0.20 & 0.16 & 0.21 & 0.21 & 0.20 & 0.22 & 0.20 & bdl & bdl & bdl & bdl \\
\hline $\mathrm{Pr}_{2} \mathrm{O}_{3}$ & 0.05 & 0.03 & 0.05 & 0.05 & 0.03 & 0.05 & 0.06 & bdl & bdl & 0.03 & bdl \\
\hline $\mathrm{Dy}_{2} \mathrm{O}_{3}$ & 0.28 & 0.31 & 0.27 & 0.30 & 0.29 & 0.26 & 0.24 & bdl & bdl & 0.06 & bdl \\
\hline $\mathrm{Er}_{2} \mathrm{O}_{3}$ & 0.05 & 0.07 & 0.04 & 0.06 & 0.04 & 0.07 & 0.04 & bdl & bdl & bdl & bdl \\
\hline $\mathrm{Al}_{2} \mathrm{O}_{3}$ & bdl & bdl & bdl & bdl & bdl & bdl & bdl & 0.22 & 0.23 & 0.24 & 0.20 \\
\hline $\mathrm{MnO}$ & bdl & bdl & bdl & bdl & bdl & bdl & bdl & 0.62 & 0.64 & 0.59 & 0.62 \\
\hline $\mathrm{PbO}$ & 1.86 & 1.83 & 1.85 & 1.86 & 1.83 & 1.89 & 1.90 & 1.02 & 0.18 & 2.20 & 0.69 \\
\hline $\mathrm{FeO}$ & 0.51 & 0.47 & 0.51 & 0.51 & 0.53 & 0.51 & 0.50 & 3.12 & 2.95 & 2.83 & 3.58 \\
\hline $\mathrm{CaO}$ & 4.43 & 4.48 & 4.45 & 4.35 & 4.52 & 4.43 & 4.37 & 2.23 & 2.32 & 2.22 & 2.16 \\
\hline Total & 99.39 & 98.85 & 99.00 & 99.39 & 99.81 & 99.48 & 99.83 & 95.95 & 96.79 & 94.93 & 95.59 \\
\hline Age $[\mathrm{Ma}]$ & $157.2 \pm 2.4$ & $155.4 \pm 2$ & $157.1 \pm 2$ & $157.2 \pm 2$ & $154.0 \pm 2$ & $159.5 \pm 2$ & $159.9 \pm 2$ & - & $16 \pm 1$ & $204 \pm 4$ & $63 \pm 2$ \\
\hline \multicolumn{12}{|c|}{ Formula calculated on the basis of $\Sigma$ all cations $=1 \mathrm{apfu}$} \\
\hline $\mathrm{As}^{5+}$ & 0.007 & 0.007 & 0.007 & 0.007 & 0.006 & 0.007 & 0.007 & & & & \\
\hline $\mathrm{P}^{5+}$ & 0.004 & 0.004 & 0.004 & 0.004 & 0.005 & 0.004 & 0.003 & & & & \\
\hline$\Sigma T$ & 0.011 & 0.011 & 0.011 & 0.011 & 0.011 & 0.011 & 0.010 & & & & \\
\hline $\mathrm{U}^{4+}$ & 0.560 & 0.557 & 0.558 & 0.564 & 0.556 & 0.562 & 0.566 & & & & \\
\hline $\mathrm{U}^{6+}$ & 0.180 & 0.183 & 0.181 & 0.177 & 0.182 & 0.180 & 0.177 & & & & \\
\hline U total & 0.740 & 0.640 & 0.739 & 0.741 & 0.738 & 0.742 & 0.743 & & & & \\
\hline $\mathrm{Y}^{3+}$ & 0.008 & 0.008 & 0.009 & 0.008 & 0.008 & 0.008 & 0.008 & & & & \\
\hline $\mathrm{Nd}^{3+}$ & 0.004 & 0.003 & 0.004 & 0.004 & 0.004 & 0.004 & 0.004 & & & & \\
\hline $\mathrm{Sm}^{3+}$ & 0.002 & 0.002 & 0.001 & 0.003 & 0.002 & 0.000 & 0.001 & & & & \\
\hline $\mathrm{Gd}^{3+}$ & 0.003 & 0.003 & 0.003 & 0.003 & 0.003 & 0.002 & 0.003 & & & & \\
\hline $\mathrm{La}^{3+}$ & 0.000 & - & - & - & 0.000 & 0.001 & 0.000 & & & & \\
\hline $\mathrm{Ce}^{3+}$ & 0.003 & 0.002 & 0.003 & 0.003 & 0.003 & 0.003 & 0.003 & & & & \\
\hline $\operatorname{Pr}^{3+}$ & 0.001 & 0.000 & 0.001 & 0.001 & 0.000 & 0.001 & 0.001 & & & & \\
\hline $\mathrm{Dy}^{3+}$ & 0.004 & 0.004 & 0.003 & 0.004 & 0.004 & 0.003 & 0.003 & & & & \\
\hline $\mathrm{Er}^{3+}$ & 0.001 & 0.001 & 0.000 & 0.001 & 0.000 & 0.001 & 0.000 & & & & \\
\hline$\Sigma \mathrm{Y}+R E E$ & 0.025 & 0.023 & 0.024 & 0.027 & 0.024 & 0.023 & 0.023 & & & & \\
\hline $\mathrm{Pb}^{2+}$ & 0.019 & 0.019 & 0.019 & 0.019 & 0.019 & 0.019 & 0.019 & & & & \\
\hline $\mathrm{Fe}^{2+}$ & 0.016 & 0.015 & 0.016 & 0.016 & 0.017 & 0.016 & 0.016 & & & & \\
\hline $\mathrm{Ca}^{2+}$ & 0.180 & 0.183 & 0.181 & 0.177 & 0.182 & 0.180 & 0.177 & & & & \\
\hline$\Sigma M^{2+}$ & 0.215 & 0.217 & 0.216 & 0.212 & 0.218 & 0.217 & 0.212 & & & & \\
\hline
\end{tabular}

bdl - below the detection limit

Composition of the rims was not recalculated due to a large chemical variability, caused by inhomogeneities (partial coffinitization)

\subsection{Supergene minerals}

\subsubsection{Brochantite, $\mathrm{Cu}_{4}\left(\mathrm{SO}_{4}\right)(\mathrm{OH})_{6}$}

Abundant brochantite forms rich, fine crystalline aggregates of grass to emerald green color (Fig. 3a), reaching up to $4 \mathrm{~mm}$ across. These aggregates are relatively abundant, partly in the material found at the footwall and growing directly on the relics of ore accumulation on the hanging-wall. Brochantite is commonly associated with cuprosklodowskite; however, it was identified in association with all other phases identified at the site, even if spatially isolated. Rarely, brochantite overgrows older uranyl-sulfates. 


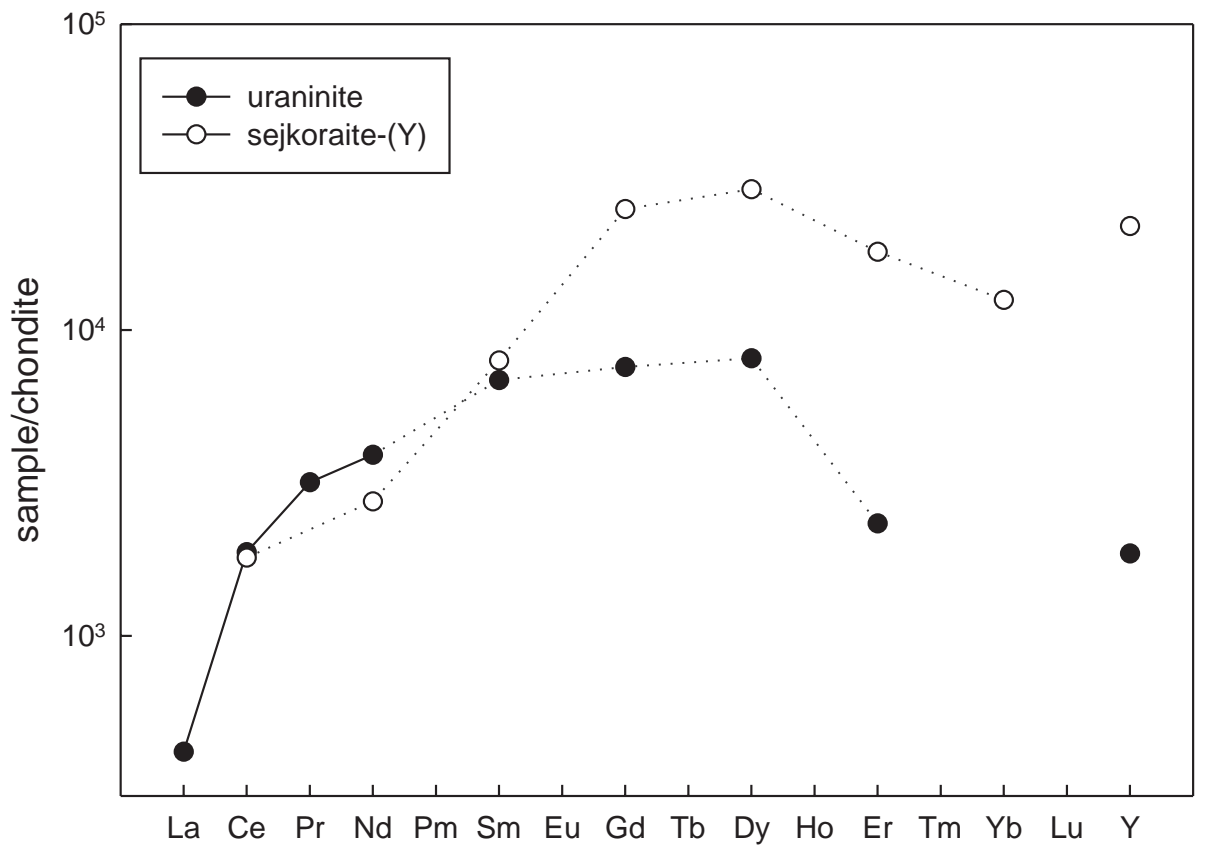

Fig. 2 Chondrite-normalized (McDonough and Sun 1995) REE patterns for uraninite and sejkoraite-(Y).
The quick chemical check by electron microprobe (ED spectrum and one measured point in WDS mode, only) confirmed that the main constituents are $\mathrm{Cu}, \mathrm{S}$ and $\mathrm{O}$.

Powder X-ray data show that brochantite is probably of $M D O_{1}$ polytype (Merlino et al. 2003), crystallizing in the space group $P 12_{1} / a 1$. The second polytype, $M D O_{2}$, $P 2_{1} / n 11$ provides a somewhat distinct powder pattern (see e.g., Mills et al. 2010). The unit-cell parameters obtained from the Le Bail fit are given in Tab. 2 and compared with the published data for this mineral.

In several powder-diffraction patterns of brochantite a few diffraction peaks that might be assigned to antlerite were found. This suggests that antlerite might form part of the powder mixtures with brochantite.

\subsubsection{Jarosite, $\mathrm{KFe}_{3}\left(\mathrm{SO}_{4}\right)_{2}(\mathrm{OH})_{6}$}

Jarosite is fairly abundant in the material found at the underground site. It forms powdery coatings consisting of globular aggregates. These have irregular shape and uneven surface. The individual globules do not exceed $1 \mathrm{~mm}$ in size. Jarosite has creamy whitish beige to whitish orange-brownish color (Fig. 3b). It was found in most specimens; however, its position in the alteration sequence cannot be deduced from the macroscopic observations.

Based on EMPA study, the chemical composition of the studied jarosite can be expressed by the empirical formula: $\left(\mathrm{K}_{0.76} \mathrm{Ba}_{0.05} \mathrm{Na}_{0.02} \mathrm{Ca}_{0.01}\right)_{\Sigma 0.84}\left(\mathrm{Fe}_{2.33} \mathrm{Cu}_{0.27} \mathrm{Al}_{0.26}\right)_{\Sigma 2.89}$ $\left[\left(\mathrm{SO}_{4}\right)_{1.93}\left(\mathrm{PO}_{4}\right)_{0.05}\left(\mathrm{SiO}_{4}\right)_{0.01}\left(\mathrm{AsO}_{4}\right)_{0.01}\right]_{\Sigma 2.00}(\mathrm{OH})_{5.15} \mathrm{Cl}_{0.02}$ (calculated as the mean of 5 points, on the basis of $\mathrm{S}+\mathrm{P}+$ $\mathrm{Si}+\mathrm{As}=2 \mathrm{apfu}$ ) (Tab. 3). The low totals of the analyses are most probably caused by the extremely porous nature of the studied aggregates.

The presence of jarosite was confirmed by the X-ray powder diffraction. The unit-cell parameters refined from the data are given in Tab. 4 in comparison with those for natural and synthetic jarosites from the literature.

\subsubsection{Compreignacite, $\mathrm{K}_{2}\left[\left(\mathrm{UO}_{2}\right)_{3} \mathrm{O}_{2}\right.$ $\left.(\mathrm{OH})_{3}\right]_{2}\left(\mathrm{H}_{2} \mathrm{O}\right)_{7}$ and related phases}

Compreignacite is relatively uncommon in the material studied. It forms rarely globular or irregularly shaped

Tab. 2 Comparison of the unit-cell parameters for brochantite polytypes

\begin{tabular}{|c|c|c|c|c|c|c|c|c|}
\hline Polytype; SG & Locality & Reference & Method & $a[\AA]$ & $b[\AA]$ & $c[\AA]$ & beta $\left[{ }^{\circ}\right]$ & $V\left[\AA^{3}\right]$ \\
\hline$M D O_{1} ; P 12_{1} / a 1$ & Červená vein & This paper & Le Bail* & $13.1344(9)$ & $9.8463(6)$ & $6.0166(3)$ & $103.20(1)$ & $757.55(4)$ \\
\hline$M D O_{1} ; P 12_{1} / a 1$ & Val Fucinaia, Italy & Merlino et al. (2003) & SC & $13.140(2)$ & $9.863(2)$ & $6.024(1)$ & $103.16(3)$ & $794.62(2)$ \\
\hline$M D O_{1} ; P 12_{1} / a 1$ & Douglas Hill mine, Nevada, USA & Mills et al. (2010) & $\mathrm{SC}$ & $13.1117(4)$ & $9.8654(4)$ & $6.0307(9)$ & $103.255(7)$ & - \\
\hline$M D O_{1} ; P 12_{1} / a 1$ & Měděnec, Czech Republic & Sejkora and Šrein (2012) & LS & $13.128(1)$ & $9.8627(8)$ & $6.0345(7$ & $103.306(8)$ & $760.3(1)$ \\
\hline$M D O_{1} ; P 12_{1} / a 1$ & Synthetic & Zittlau et al. (2013) & Rietveld & $13.1293(3)$ & $9.865(3)$ & $6.022(1)$ & $103.274(4)$ & - \\
\hline$M D O_{2} ; P 2_{1} / n 11$ & Capo Calamita, Italy & Merlino et al. (2003) & $\mathrm{SC}$ & $12.776(2)$ & $9.869(2)$ & $6.026(1)$ & $90.15(3)$ & - \\
\hline
\end{tabular}

$* R_{\mathrm{p}}=0.0103, w R_{\mathrm{p}}=1.29, \mathrm{GOF}=1$ (after Young 1993). Bérar's correction applied (Bérar and Lellann 1991)

$\mathrm{SG}$ - space group, $\mathrm{SC}$ - single crystal data, LS - least-square refinement from PXRD 

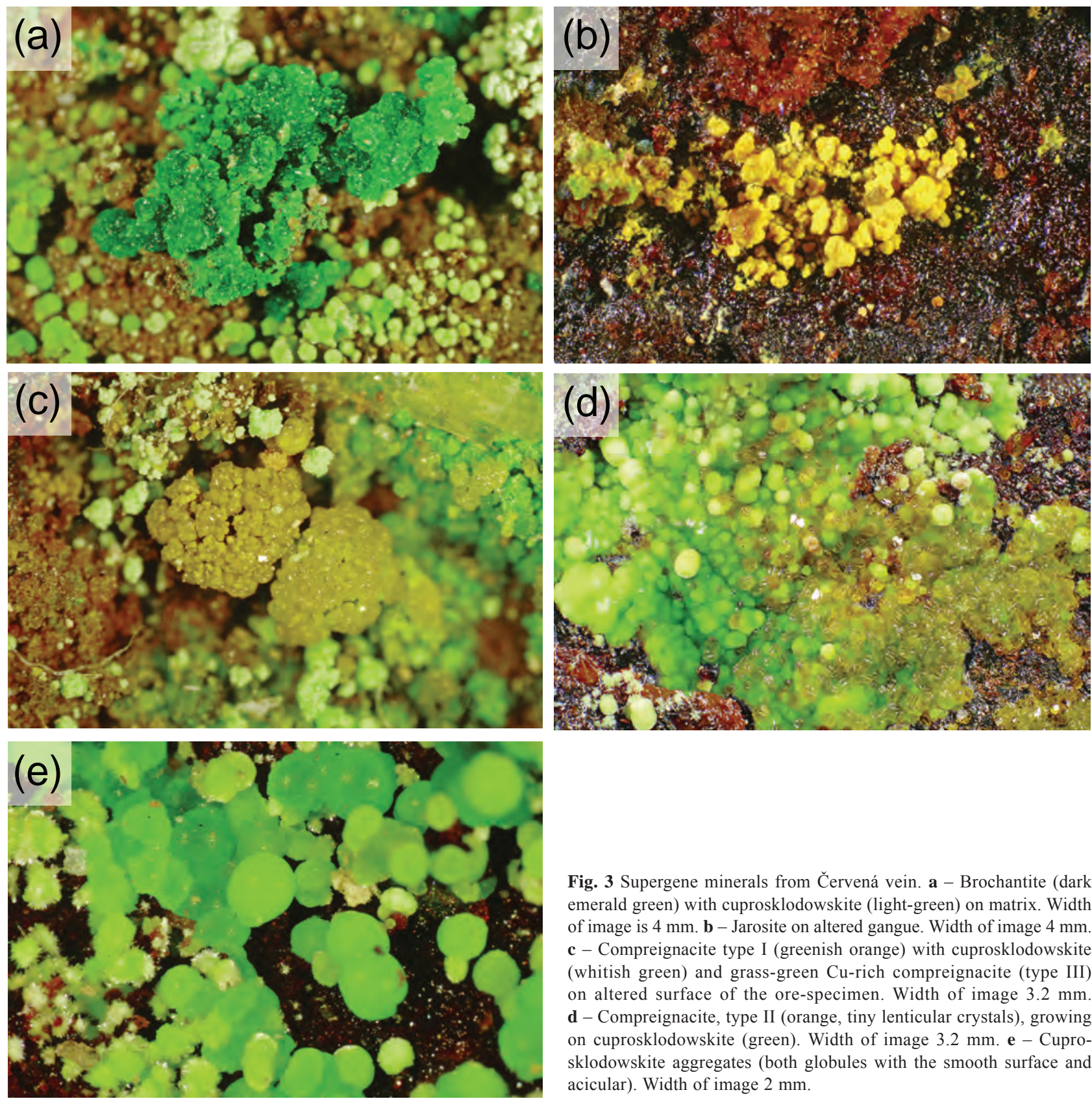

Fig. 3 Supergene minerals from Červená vein. a - Brochantite (dark emerald green) with cuprosklodowskite (light-green) on matrix. Width of image is $4 \mathrm{~mm}$. b - Jarosite on altered gangue. Width of image $4 \mathrm{~mm}$. c - Compreignacite type I (greenish orange) with cuprosklodowskite (whitish green) and grass-green $\mathrm{Cu}$-rich compreignacite (type III) on altered surface of the ore-specimen. Width of image $3.2 \mathrm{~mm}$. d - Compreignacite, type II (orange, tiny lenticular crystals), growing on cuprosklodowskite (green). Width of image $3.2 \mathrm{~mm}$. e - Cuprosklodowskite aggregates (both globules with the smooth surface and acicular). Width of image $2 \mathrm{~mm}$.

aggregates, which do not exceed $1 \mathrm{~mm}$ in size. They have creamy orange-to-orange color and are associated with cuprosklodowskite and gypsum growing on altered gangue (Fig. 3c). On a one specimen compreignacite formed crystalline aggregates in association with pseudojohannite, rabejacite and gypsum.

Three types of compreignacite crystals were distinguished based on their chemistry. First are rich crystalline aggregates, present only on the single specimen (Fig. 3c). Analyses showed the prevalence of $\mathrm{K}^{+}$at the cationic site; however, namely $\mathrm{Cu}^{2+}$ was detected in significant concentrations. The chemical composition of studied compreignacite can be expressed by the empirical formula (calculated as the mean of 4 analyses, on the basis of 6 $\mathrm{U}$ apfu $):\left(\mathrm{K}_{0.91} \mathrm{Cu}_{0.37} \mathrm{Mg}_{0.07} \mathrm{Al}_{0.03}\right)_{\Sigma 1.38}\left(\mathrm{UO}_{2}\right)_{3} \mathrm{O}_{2}\left\{\left(\mathrm{SiO}_{4}\right)_{0.13}\right.$ $\left.\left.\left(\mathrm{SO}_{4}\right)_{0.03}\right\}_{\Sigma 0.16}\left\{(\mathrm{OH})_{2.17} \mathrm{~F}_{0.19}\right\}_{\Sigma 2.36}\right]_{2}\left(\mathrm{H}_{2} \mathrm{O}\right)_{7}$ (Tab. 5).

The second type of compreignacite is represented by rounded crystals (Fig. 1b) associated with cuprosklodowskite (Fig. 3d). The crystals are usually orange. The chemical composition can be expressed as: $\left(\mathrm{K}_{1.00}\right.$ $\left.\mathrm{Cu}_{0.24} \mathrm{Ca}_{0.04}\right)_{\Sigma 1.28}\left[\left(\mathrm{UO}_{2}\right)_{3} \mathrm{O}_{2}\left\{\left(\mathrm{SiO}_{4}\right)_{0.21}\left(\mathrm{SO}_{4}\right)_{0.03}\right\}_{\Sigma 0.23}(\mathrm{OH})_{1.84}\right]_{2}$ $\left(\mathrm{H}_{2} \mathrm{O}\right)_{7}$ (mean of 4 point analyses, calculated on the basis of $6 \mathrm{U}$ apfu) (Tab. 5).

Both analyzed types thus correspond to a cationdeficient compregnacite (Fig. 4) with increased Si/S content, similar to compreignacite recently described 
Tab. 3 Chemical composition of jarosite from the vein Červená (in wt. \%)

\begin{tabular}{|c|c|c|c|c|c|c|}
\hline & Mean & 1 & 2 & 3 & 4 & 5 \\
\hline $\mathrm{Na}_{2} \mathrm{O}$ & 0.06 & 0.07 & 0.07 & 0.07 & 0.06 & bdl \\
\hline $\mathrm{K}_{2} \mathrm{O}$ & 4.41 & 4.41 & 4.46 & 4.40 & 4.50 & 4.30 \\
\hline $\mathrm{CaO}$ & 0.10 & 0.10 & 0.09 & 0.12 & 0.09 & 0.10 \\
\hline $\mathrm{Fe}_{2} \mathrm{O}_{3}$ & 22.89 & 22.37 & 23.25 & 23.96 & 23.38 & 22.51 \\
\hline $\mathrm{Al}_{2} \mathrm{O}_{3}$ & 1.62 & 1.64 & 1.64 & 1.57 & 1.59 & 1.66 \\
\hline $\mathrm{CuO}$ & 2.61 & 2.64 & 2.69 & 2.57 & 2.45 & 2.71 \\
\hline $\mathrm{PbO}$ & 0.82 & 0.87 & 1.00 & 0.87 & 0.71 & 0.63 \\
\hline $\mathrm{SiO}_{2}$ & 0.10 & 0.09 & 0.08 & 0.09 & 0.12 & 0.10 \\
\hline $\mathrm{P}_{2} \mathrm{O}_{5}$ & 0.47 & 0.46 & 0.45 & 0.54 & 0.45 & 0.43 \\
\hline $\mathrm{As}_{2} \mathrm{O}_{5}$ & 0.10 & 0.10 & 0.08 & 0.08 & 0.22 & bdl \\
\hline $\mathrm{SO}_{3}$ & 18.99 & 19.04 & 19.21 & 19.08 & 19.27 & 18.36 \\
\hline $\mathrm{Cl}$ & 0.38 & 0.11 & 0.05 & 0.07 & 0.08 & 0.08 \\
\hline$-\mathrm{O}=\mathrm{Cl}$ & 0.02 & 0.02 & 0.01 & 0.02 & 0.02 & 0.02 \\
\hline $\mathrm{H}_{2} \mathrm{O}^{*}$ & 5.72 & & & & & \\
\hline Total & 58.91 & 52.79 & 53.90 & 53.35 & 53.88 & 52.04 \\
\hline $\mathrm{Na}^{+}$ & 0.018 & 0.018 & 0.018 & 0.019 & 0.016 & \\
\hline $\mathrm{K}^{+}$ & 0.761 & 0.760 & 0.762 & 0.752 & 0.761 & 0.769 \\
\hline $\mathrm{Ca}^{2+}$ & 0.015 & 0.014 & 0.012 & 0.017 & 0.013 & 0.015 \\
\hline $\mathrm{Pb}^{2+}$ & 0.030 & 0.032 & 0.036 & 0.032 & 0.025 & 0.024 \\
\hline$\Sigma A$ site & 0.824 & 0.824 & 0.828 & 0.820 & 0.815 & 0.808 \\
\hline $\mathrm{Fe}^{3+}$ & 2.329 & 2.272 & 2.345 & 2.318 & 2.334 & 2.379 \\
\hline $\mathrm{Al}^{3+}$ & 0.258 & 0.260 & 0.259 & 0.248 & 0.249 & 0.274 \\
\hline $\mathrm{Cu}^{2+}$ & 0.267 & 0.270 & 0.273 & 0.260 & 0.246 & 0.287 \\
\hline ¿O site & 2.854 & 2.802 & 2.877 & 2.826 & 2.829 & 2.940 \\
\hline $\mathrm{SiO}_{4}$ & 0.013 & 0.011 & 0.011 & 0.012 & 0.016 & 0.014 \\
\hline $\mathrm{PO}_{4}$ & 0.053 & 0.052 & 0.051 & 0.062 & 0.050 & 0.051 \\
\hline $\mathrm{AsO}_{4}$ & 0.008 & 0.007 & 0.006 & 0.006 & 0.015 & \\
\hline $\mathrm{SO}_{4}$ & 1.926 & 1.930 & 1.932 & 1.920 & 1.919 & 1.935 \\
\hline$\Sigma T$ site & 2.000 & 2.000 & 2.000 & 2.000 & 2.000 & 2.000 \\
\hline $\mathrm{Cl}$ & 0.018 & 0.025 & 0.011 & 0.016 & 0.018 & 0.019 \\
\hline $\mathrm{OH}^{\$}$ & 5.152 & 4.999 & 5.232 & 5.078 & 5.080 & 5.413 \\
\hline
\end{tabular}

* - calculated for the content of $\mathrm{OH}$ in the formula $\left(\mathrm{OH}^{\$}\right)$, derived from the charge-balance

bdl - below the detection limit;

coefficients of the empirical formula calculated on the basis of $\mathrm{Si}+\mathrm{P}$ $+\mathrm{As}+\mathrm{S}=2$ apfu.

from the Evangelista vein, Jáchymov (Sejkora et al. 2013). Remarkable are zones of compreignacite aggregates (Fig. 3c, green) containing high $\mathrm{Cu}$. The elevated
$\mathrm{Cu}^{2+}$ is typical of compreignacite from the Červená vein. Moreover, a few point analyses were found to belong to the $\mathrm{Cu}$-dominant phase (labeled as "Type III"; Fig. 4) with an empirical formula: $\left(\mathrm{Cu}_{0.84} \mathrm{Ca}_{0.65} \mathrm{~K}_{0.52}\right)_{\Sigma 2.01}\left[\left(\mathrm{UO}_{2}\right)_{3}\right.$ $\left.\mathrm{O}_{2}\left\{\left(\mathrm{SO}_{4}\right)_{0.25}\left(\mathrm{SiO}_{4}\right)_{0.15}\right\}_{\Sigma 0.40}(\mathrm{OH})_{2.38}\right]_{2}\left(\mathrm{H}_{2} \mathrm{O}\right)_{7}$ (average of 2 point analyses, calculated on the basis of $6 \mathrm{U}$ apfu) (Tab. 5).

The only known $\mathrm{Cu}$-uranyl-oxide hydroxy-hydrate mineral worldwide is vandenbrandeite, $\mathrm{Cu}\left[\left(\mathrm{UO}_{2}\right)(\mathrm{OH})_{4}\right]$ (Schoep 1932). However, the sheets in the crystal structure of vandenbrandeite (Rosenzweig and Ryan 1977) are based upon the topology, which is distinct from that of protasite to which compreignacite also belongs (Burns 2005). Moreover, the $\mathrm{Ca}^{2+}$-content in studied phase probably corresponds with the mineral becquerelite, based upon the same topology as compreignacite. We conclude that an existence of the new $\mathrm{Cu}$-dominant uranyl-oxide hydroxy-hydrate mineral that can contain structural sheets based upon protasite anion topology, is likely. The incorporation of the $\mathrm{SiO}_{4}$ or $\mathrm{SO}_{4}$ anions is generally conceivable (up to the extent permitted by the charge-balancing mechanism), since the sheets in compreignacite are based upon pentagons and triangles that might be occupied by tetrahedrally coordinated anions.

The unit-cell parameters of typical orange compreignacite (type I), refined from the powder X-ray diffraction data, are similar to those reported from other localities (Tab. 6).

\subsubsection{Cuprosklodowskite, $\mathrm{Cu}\left[\left(\mathrm{UO}_{2}\right)_{2}\right.$ $\left.\left(\mathrm{SiO}_{3} \mathrm{OH}\right)_{2}\right]\left(\mathrm{H}_{2} \mathrm{O}\right)_{6}$}

Cuprosklodowskite is relatively abundant in the studied association. It forms rich crystalline globular aggregates (up to $1 \mathrm{~mm}$ across for the individual spherules) of the light green color (Fig. 3e). It is associated almost with all minerals identified at the site. Aggregates of cuprosklodowskite consist of very fine, minute prismatic crystals (Fig. 1c). Cuprosklodowskite is often associated with gypsum and, additionally, on a one sample, it formed

Tab. 4 Comparison of the unit-cell parameters for jarosite-subgroup of minerals (for the trigonal space group $R \overline{3} m$ )

\begin{tabular}{|c|c|c|c|c|c|c|c|}
\hline Mineral & Composition & Locality & Reference & Method & $a[\AA]$ & $c[\AA ̊]$ & $V\left[\AA^{3}\right]$ \\
\hline Jarosite & $\left(\mathrm{K}_{0.76} \mathrm{Ba}_{0.05} \mathrm{Na}_{0.02} \mathrm{Ca}_{0.01}\right)_{\Sigma 0.84}\left(\mathrm{Fe}_{2.33} \mathrm{Cu}_{0.27} \mathrm{Al}_{0.26}\right)_{\Sigma 2.86}$ & Červená & this paper & Le Bail* & $7.2635(1)$ & $17.1969(6)$ & $785.72(3)$ \\
\hline Jarosite & $\mathrm{K}_{0.95}\left(\mathrm{H}_{3} \mathrm{O}\right)_{0.05} \mathrm{Fe}_{2.87} \cdots$ & Synthetic & $\begin{array}{l}\text { Basciano and } \\
\text { Peterson (2007) }\end{array}$ & Rietveld & $7.30293(8)$ & $17.2043(2)$ & $794.62(2)$ \\
\hline Jarosite & $\mathrm{K}_{0.99}\left(\mathrm{H}_{3} \mathrm{O}\right)_{0.01} \mathrm{Fe}_{2.97} \cdots$ & Synthetic & $\begin{array}{l}\text { Basciano and } \\
\text { Peterson }(2010)\end{array}$ & Rietveld & $7.3046(1)$ & $17.2120(3)$ & 795.35 \\
\hline Natrojarosite & K-containing natrojarosite & $\begin{array}{l}\text { Xitieshan, } \\
\text { Tibet }\end{array}$ & $\begin{array}{l}\text { Chen et al. } \\
(2013)\end{array}$ & Rietveld & $7.3112(2)$ & $16.5993(3)$ & 768.42 \\
\hline Natrojarosite & $\mathrm{NaFe}_{3} \ldots$ & Synthetic & $\begin{array}{l}\text { Basciano and } \\
\text { Peterson (2008) }\end{array}$ & Rietveld & $7.31525(6)$ & $16.5868(2)$ & 768.68 \\
\hline Plumbojarosite & $\mathrm{Pb}_{0.34} \mathrm{~K}_{0.16}\left(\mathrm{H}_{3} \mathrm{O}\right)_{0.16} \mathrm{Fe}_{2.95} \ldots$ & Synthetic & $\begin{array}{l}\text { Basciano and } \\
\text { Peterson (2010) }\end{array}$ & Rietveld & $7.3185(2)$ & $33.7274(8)$ & 1564.4 \\
\hline \multicolumn{2}{|c|}{ Hydroniumjarosite $\left(\mathrm{H}_{3} \mathrm{O}\right)_{0.91} \mathrm{Fe}_{2.91} \ldots$} & Synthetic & $\begin{array}{l}\text { Majzlan et al. } \\
(2004)\end{array}$ & $\mathrm{SC}$ & $7.3559(8)$ & $17.0186(27)$ & $797.5(2)$ \\
\hline
\end{tabular}


Tab. 5 Chemical composition of compreignacite-like minerals from the vein Červená (in wt. \%)

\begin{tabular}{|c|c|c|c|c|c|c|c|c|c|c|c|c|c|}
\hline & & & Type I & & & & & Type II & & & & Type III & \\
\hline & Mean & 1 & 2 & 3 & 4 & Mean & 5 & 6 & 7 & 8 & Mean & 9 & 10 \\
\hline $\mathrm{K}_{2} \mathrm{O}$ & 2.23 & 2.27 & 2.30 & 2.20 & 2.16 & 2.44 & 2.63 & 2.25 & 2.61 & 2.28 & 1.10 & 1.13 & 1.06 \\
\hline $\mathrm{MgO}$ & 0.14 & 0.13 & 0.19 & 0.04 & 0.22 & bdl & bdl & bdl & bdl & bdl & 0.06 & 0.13 & 0.00 \\
\hline $\mathrm{CaO}$ & bdl & bdl & bdl & bdl & bdl & 0.10 & 0.04 & 0.07 & 0.12 & 0.18 & 0.96 & 0.33 & 1.59 \\
\hline $\mathrm{Al}_{2} \mathrm{O}_{3}$ & 0.08 & 0.06 & 0.11 & 0.03 & 0.10 & bdl & bdl & bdl & bdl & bdl & bdl & bdl & bdl \\
\hline $\mathrm{CuO}$ & 1.53 & 1.32 & 1.50 & 1.50 & 1.79 & 1.00 & 0.00 & 1.79 & 1.03 & 1.17 & 3.09 & 3.28 & 2.90 \\
\hline $\mathrm{SiO}_{2}$ & 0.82 & 0.52 & 0.56 & 1.15 & 1.07 & 1.30 & 1.05 & 1.76 & 0.60 & 1.77 & 0.83 & 0.52 & 1.15 \\
\hline $\mathrm{SO}_{3}$ & 0.20 & 0.10 & 0.00 & 0.29 & 0.40 & 0.27 & 0.19 & 0.35 & 0.33 & 0.23 & 1.80 & 0.66 & 2.94 \\
\hline $\mathrm{UO}_{3}$ & 89.05 & 89.10 & 89.65 & 87.94 & 89.51 & 89.02 & 91.08 & 86.89 & 88.80 & 89.32 & 80.41 & 86.11 & 74.72 \\
\hline $\mathrm{F}$ & 0.38 & 0.36 & 0.36 & 0.34 & 0.46 & bdl & bdl & bdl & bdl & bdl & bdl & bdl & bdl \\
\hline$-\mathrm{O}=\mathrm{F}$ & 0.16 & 0.15 & 0.15 & 0.14 & 0.19 & & & & & & & & \\
\hline $\mathrm{H}_{2} \mathrm{O}^{*}$ & 8.56 & & & & & 8.30 & & & & & 7.94 & & \\
\hline Total & 102.84 & 93.70 & 94.51 & 93.34 & 95.51 & 102.43 & 93.70 & 94.51 & 93.34 & 95.51 & 96.19 & 92.16 & 84.34 \\
\hline $\mathrm{K}$ & 0.913 & 0.928 & 0.934 & 0.913 & 0.877 & 0.999 & 1.052 & 0.941 & 1.070 & 0.929 & 0.497 & 0.478 & 0.516 \\
\hline $\mathrm{Mg}$ & 0.069 & 0.061 & 0.089 & 0.019 & 0.105 & - & - & - & - & - & 0.031 & 0.063 & 0.000 \\
\hline $\mathrm{Ca}$ & - & - & - & - & - & 0.035 & 0.013 & 0.026 & 0.040 & 0.061 & 0.384 & 0.117 & 0.650 \\
\hline $\mathrm{Al}$ & 0.029 & 0.022 & 0.042 & 0.012 & 0.038 & - & - & - & - & - & - & - & - \\
\hline $\mathrm{Cu}$ & 0.370 & 0.320 & 0.361 & 0.367 & 0.431 & 0.242 & 0.000 & 0.446 & 0.251 & 0.283 & 0.829 & 0.822 & 0.837 \\
\hline$\Sigma A$ & 1.381 & 1.331 & 1.436 & 1.311 & 1.451 & 1.276 & 1.065 & 1.413 & 1.368 & 1.273 & 1.741 & 1.480 & 2.003 \\
\hline $\mathrm{SiO}_{4}$ & 0.264 & 0.165 & 0.178 & 0.372 & 0.340 & 0.415 & 0.330 & 0.580 & 0.192 & 0.565 & 0.305 & 0.171 & 0.438 \\
\hline $\mathrm{SO}_{4}$ & 0.048 & 0.024 & 0.000 & 0.072 & 0.095 & 0.066 & 0.045 & 0.085 & 0.079 & 0.055 & 0.504 & 0.165 & 0.843 \\
\hline$\Sigma T$ site & 0.312 & 0.189 & 0.178 & 0.444 & 0.435 & 0.481 & 0.375 & 0.665 & 0.271 & 0.620 & 0.809 & 0.336 & 1.281 \\
\hline $\mathrm{UO}_{2}{ }^{2+}$ & 6.000 & 6.000 & 6.000 & 6.000 & 6.000 & 6.000 & 6.000 & 6.000 & 6.000 & 6.000 & 6.000 & 6.000 & 6.000 \\
\hline $\mathrm{OH}^{\$}$ & 4.339 & 4.679 & 4.887 & 3.743 & 4.049 & 3.760 & 3.667 & 3.934 & 4.728 & 3.247 & 4.760 & 5.468 & 4.052 \\
\hline F & 0.385 & 0.366 & 0.363 & 0.347 & 0.465 & - & - & - & - & - & - & - & - \\
\hline $\mathrm{H}_{2} \mathrm{O}$ & 7.00 & 7.00 & 7.00 & 7.00 & 7.00 & 7.00 & 7.00 & 7.00 & 7.00 & 7.00 & 7.00 & 7.00 & 7.00 \\
\hline
\end{tabular}

Calculation on the basis of $6 \mathrm{U}$ apfu

* $\mathrm{H}_{2} \mathrm{O}$ - calculated based on stoichiometry in ideal compreignacite formula (Burns 1998); $\mathrm{OH}^{\$}-$ based on the charge-balance

intergrowths with soddyite. Usually is cuprosklodowskite closely associated with brochantite.

Chemically, studied cuprosklodowskite is slightly $\mathrm{Cu}^{2+}$ deficient. Its chemical composition (Tab. 7) can be expressed by the empirical formula (mean of 3 analyses, on the basis $\mathrm{Cu}+\mathrm{Si}+\mathrm{P}+\mathrm{U}=5$ apfu $): \mathrm{Cu}_{0.93}\left(\mathrm{UO}_{2}\right)_{2.10}$ $\left[\left\{\left(\mathrm{SiO}_{3} \mathrm{OH}\right)_{1.94}\left(\mathrm{PO}_{3} \mathrm{OH}\right)_{0.04}\right\}_{\Sigma 1.98} \mathrm{OH}_{0.16}\right]\left(\mathrm{H}_{2} \mathrm{O}\right)_{6}$.

Powder-diffraction data match well the reference patterns in the ICDD PDF2 database. The refined unit-cell parameters of cuprosklodowskite from the Červená vein are given in Tab. 8 and compared with published data for this mineral.

\subsubsection{Johannite, $\mathrm{Cu}\left[\left(\mathrm{UO}_{2}\right)_{2}\left(\mathrm{SO}_{4}\right)_{2}(\mathrm{OH})_{2}\right]$ $\left(\mathrm{H}_{2} \mathrm{O}\right)_{8}$}

Johannite is extremely rare - it was found on a single specimen as long prismatic crystals. Crystals are of the dark-green to green color and do not exceed $1 \mathrm{~mm}$ in length (Fig. 5). Johannite comes usually alone, isolated from the other minerals (on a millimeter scale). It was found in association with pseudojohannite, rabejacite, uranopilite and gypsum. The identification of the mineral has been based solely on the very typical crystal shapes (see Mereiter 1982).

\subsubsection{Soddyite, $\left(\mathrm{UO}_{2}\right)_{2}\left(\mathrm{SiO}_{4}\right)\left(\mathrm{H}_{2} \mathrm{O}\right)_{2}$}

Soddyite was found only on a single specimen. It forms yellow earthy coatings and aggregates in association with cuprosklodowskite (Fig. 6a) covering several $\mathrm{cm}^{2}$ of the matrix. These crystalline coatings are composed of fine platy crystals (Fig. 1d). It has a glassy to waxy luster.

Tab. 6 Refined unit-cell parameters for compreignacite (for the orthorhombic space group Pnnm)

\begin{tabular}{lcc}
\hline & Jáchymov (type I), this paper & Margnac (France), Burns (1998) \\
\hline$a[\AA]$ & $14.854(7)$ & $14.8591(7)$ \\
$b[\AA]$ & $7.195(4)$ & $7.1747(3)$ \\
$c[\AA]$ & $12.140(9)$ & $12.1871(5)$ \\
$V\left[\AA^{3}\right]$ & $1298(1)$ & $1299.3(2)$ \\
\hline \multicolumn{3}{c}{ H. Slavkov, Plášil et al. (2006) } \\
\hline$a[\AA]$ & $14.868(1)$ & Březové Hory, Plášil et al. (2005) \\
$b[\AA]$ & $7.2036(8)$ & $14.857(2)$ \\
$c[\AA]$ & $12.161(2)$ & $7.1779(5)$ \\
$V\left[\AA^{3}\right]$ & 1302.5 & $12.155(1)$ \\
\hline
\end{tabular}




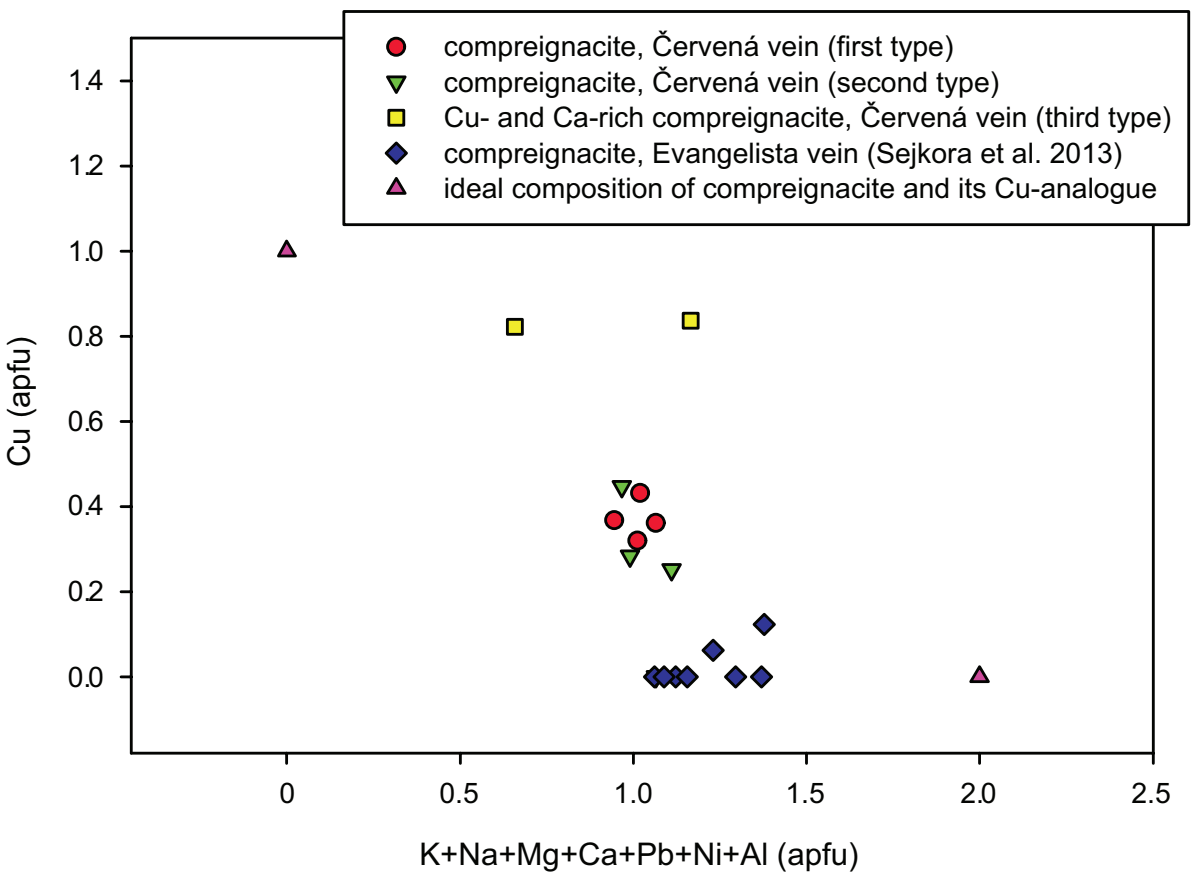

Fig. 4 Plot of $(\mathrm{K}+\mathrm{Na}+\mathrm{Mg}+\mathrm{Ca}+$ $\mathrm{Pb}+\mathrm{Ni}+\mathrm{Al}$ vs. $\mathrm{Cu}$ contents $(a p f u)$ for compreignacite-like minerals from Jáchymov (calculation of apfu on the basis of $6 \mathrm{U}$ atoms).
Powder X-ray diffraction (Tab. 9) confirmed the presence of soddyite. The refined unit-cell parameters are given in Tab. 10, together with the published data.

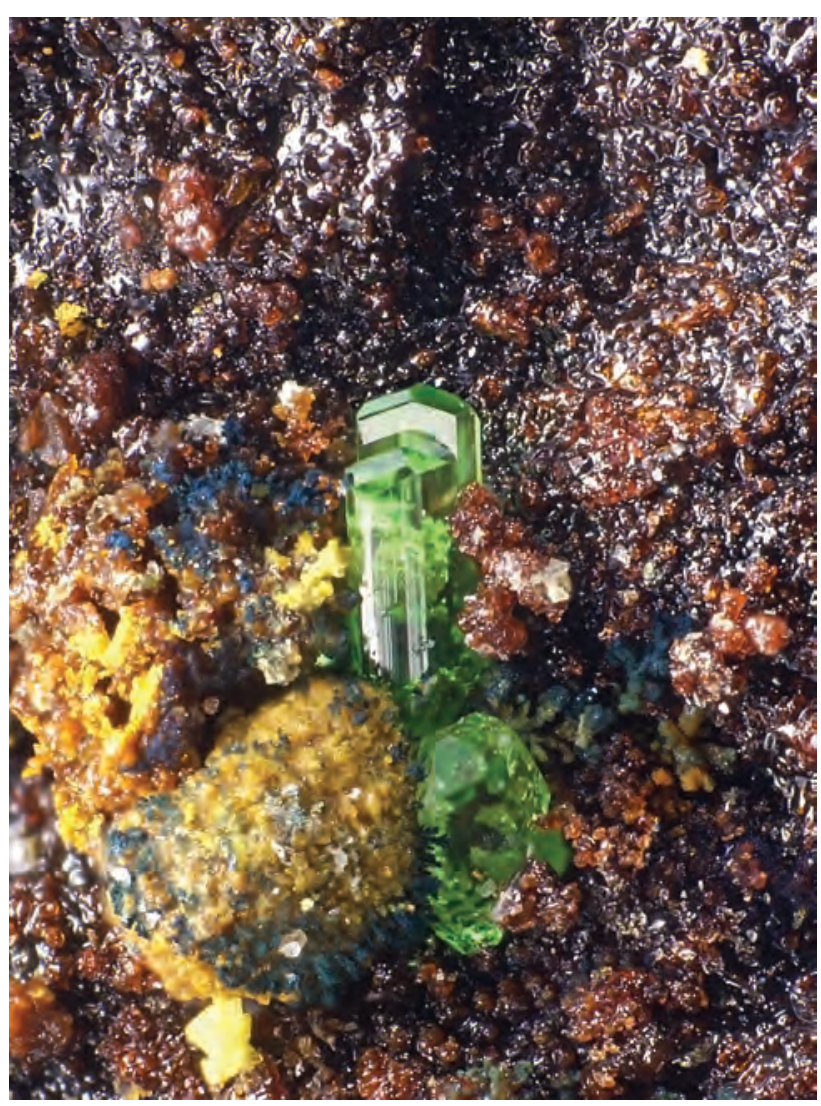

Fig. 5 Aggregate of johannite crystals, on-growing rabejacite (orangeyellow) on strongly altered matrix. Width of image $3.5 \mathrm{~mm}$.

\subsubsection{Uranyl vanadates: tyuyamunite, $\mathrm{Ca}\left(\mathrm{UO}_{2}\right)_{2} \mathrm{~V}_{2} \mathrm{O}_{8}\left(\mathrm{H}_{2} \mathrm{O}\right)_{5-8}$, sengiérite $\mathrm{Cu}_{2}\left(\mathrm{UO}_{2}\right)_{2} \mathrm{~V}_{2} \mathrm{O}_{8}\left(\mathrm{H}_{2} \mathrm{O}\right)_{6}$ and a possible Cu-analogue (CuUVO) of tyuyamunite}

Uranyl-vanadate minerals occur usually somewhat spatially separated from other uranyl minerals. They are most commonly covering the samples of host rocks including mud-rocky breccia, containing also aggregates of pargasite (Fig. 6b). Other supergene minerals found in the association are jarosite, brochantite, secondary covellite and amorphous $\mathrm{Cu}$-phases. Rarely, uranyl vanadates on-grow the altered surface of cracks of the primary minerals, namely tennantite (Fig. 6c).

Tab. 7 Chemical composition of cuprosklodowskite from the Červená vein (in wt. \%).

\begin{tabular}{lrrrr}
\hline & Mean & \multicolumn{1}{c}{1} & \multicolumn{1}{c}{2} & \multicolumn{1}{c}{3} \\
\hline $\mathrm{CuO}$ & 8.69 & 8.33 & 9.59 & 8.16 \\
$\mathrm{SiO}_{2}$ & 13.73 & 13.34 & 14.03 & 13.82 \\
$\mathrm{P}_{2} \mathrm{O}_{5}$ & 0.29 & 0.42 & 0.21 & 0.26 \\
$\mathrm{UO}_{3}$ & 70.73 & 72.20 & 68.83 & 71.15 \\
$\mathrm{H}_{2} \mathrm{O}^{*}$ & 15.00 & & & \\
\hline Total & 108.44 & 94.28 & 92.66 & 93.38 \\
\hline $\mathrm{Cu}$ & 0.927 & 0.895 & 1.009 & 0.876 \\
\hline $\mathrm{Si}$ & 1.939 & 1.898 & 1.953 & 1.966 \\
$\mathrm{P}$ & 0.035 & 0.050 & 0.024 & 0.031 \\
$\Sigma T$ site & 1.974 & 1.948 & 1.977 & 1.997 \\
\hline $\mathrm{UO}_{2}$ & 2.098 & 2.158 & 2.013 & 2.126 \\
$\mathrm{OH}$ & 2.138 & 2.260 & 2.113 & 2.042 \\
$\mathrm{H}_{2} \mathrm{O}$ & 6.00 & & & \\
\hline $\mathrm{Calcu}$ & & & &
\end{tabular}

Calculation on the basis of $\mathrm{Cu}+\mathrm{Si}+\mathrm{P}+\mathrm{U}=5$ apfu;

$\mathrm{H}_{2} \mathrm{O}^{*}$ - content from stoichiometry in ideal formula 

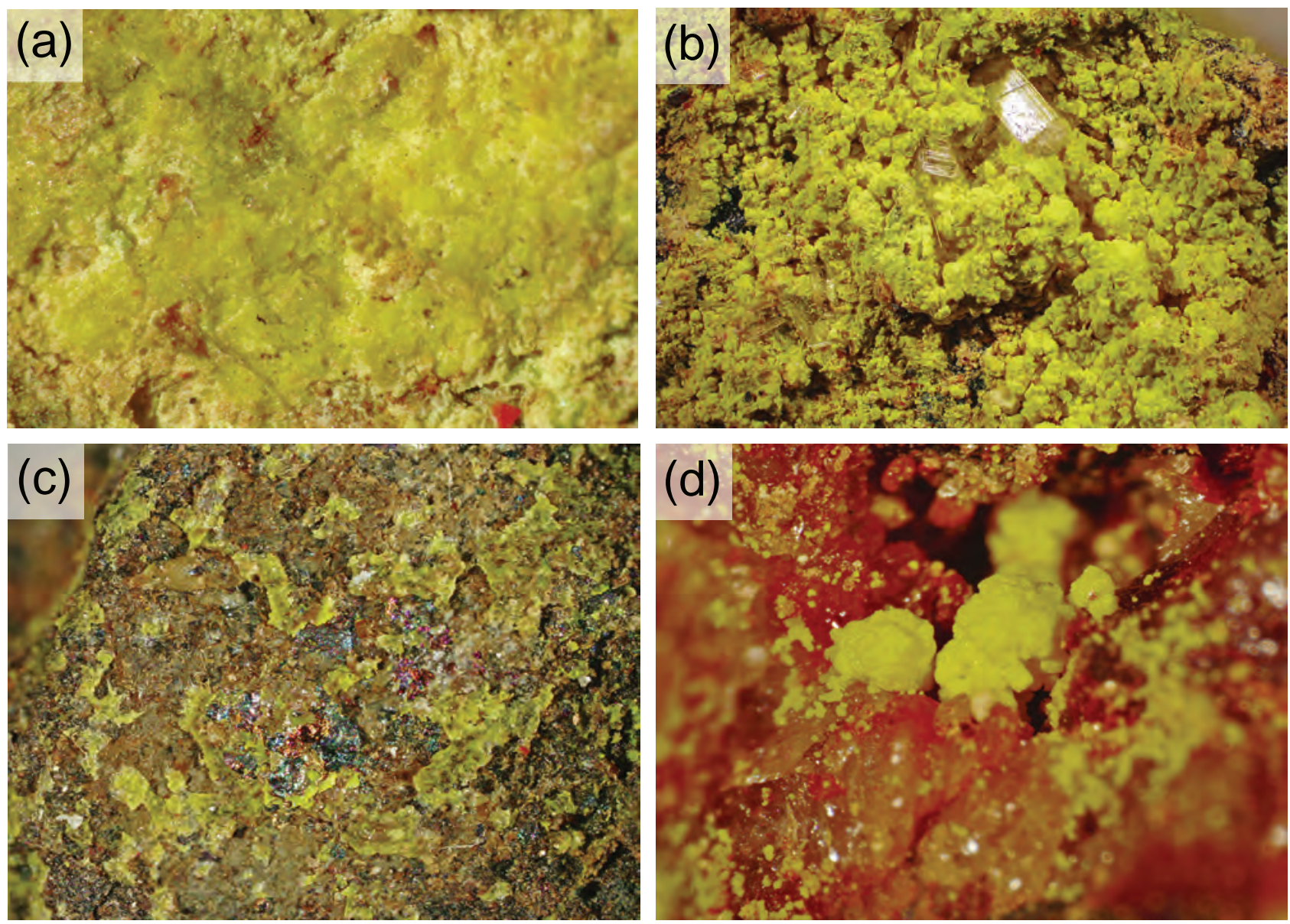

Fig. 6 Supergene uranyl-silicate and vanadate minerals from Červená vein. a - Soddyite (yellow) on the fracture of the gangue. Width of image $2 \mathrm{~mm}$. b - Crusts of uranyl-vanadates (mostly the Ca-rich variety) and gypsum (prismatic colorless crystals) growing on the surface of breccia containing pargasite fragments (blackish). Width of image $5 \mathrm{~mm}$. c - Rims of uranyl vanadates (dominated by the Cu-rich variety) enclosing altered primary sulphides (mostly chalcopyrite and tennantite). Width of image $5 \mathrm{~mm}$. d - Tyuyamunite (yellowish) crystalline aggregate in a quartz gangue. Width of image $2 \mathrm{~mm}$.

The yellowish or pale yellow parts of the aggregates (Fig. 6d) are formed by the tiny microcrystals of tyuyamunite (Fig. 1e). Their dimensions cause the broadening and a diffuse nature of the peaks in the powder X-ray diffraction pattern, making their identification and characterization difficult. The chemical analysis of tyuyamunite is summarized in Tab. 11 and can be expressed as: $\left(\mathrm{Ca}_{0.91} \mathrm{Mg}_{0.03} \mathrm{Al}_{0.02} \mathrm{Y}_{0.01} \mathrm{Ba}_{0.01}\right)_{\Sigma 0.98}\left(\mathrm{UO}_{2}\right)_{2}\left[\left(\mathrm{~V}_{2} \mathrm{O}_{8}\right)_{0.92}\left(\mathrm{SiO}_{4}\right)_{0.13}\right.$ $\left.\left(\mathrm{SO}_{4}\right)_{0.03}\right]_{\Sigma 2.00} . n \mathrm{H}_{2} \mathrm{O}$ (mean of 6 point analyses, calculated on the basis of $2 \mathrm{U} a p f u$ ).

The abundant green parts of those microcrystalline aggregates (up to several $\mathrm{mm}$ across) belong to a $\mathrm{Cu}$-dominant phase (Fig. 7). The powder diffraction is of limited use since the crystallites are very small and cause extensive broadening of the diffraction peaks. Still, much of these aggregates belongs
Tab. 8 Refined unit-cell parameters for cuprosklodowskite (for the triclinic space group $P \overline{1}$ )

\begin{tabular}{lcccc}
\hline & $\begin{array}{c}\text { Jáchymov, } \\
\text { this paper }\end{array}$ & $\begin{array}{c}\text { Musunoï, } \\
\text { Rosenzweig and Ryan (1975) }\end{array}$ & $\begin{array}{c}\text { Horní Slavkov, } \\
\text { Plásil et al. (2006) }\end{array}$ & $\begin{array}{c}\text { Zálesí, } \\
\text { Plášil et al. (2008) }\end{array}$ \\
\hline$a[\AA]$ & $7.055(9)$ & $7.052(5)$ & $7.06(1)$ & $7.055(4)$ \\
$b[\AA]$ & $9.28(2)$ & $9.267(8)$ & $9.19(1)$ & $9.263(5)$ \\
$c[\AA]$ & $6.667(8)$ & $6.655(5)$ & $6.675(7)$ & $6.655(3)$ \\
$\alpha\left[^{\circ}\right]$ & $109.16(11)$ & $109.23(5)$ & $109.54(8)$ & $109.17(3)$ \\
$\beta\left[^{\circ}\right]$ & $89.82(14)$ & $89.84(5)$ & $90.24(8)$ & $89.77(3)$ \\
$\gamma\left[^{\circ}\right]$ & $110.07(14)$ & $110.01(7)$ & $108.9(1)$ & $110.08(4)$ \\
$V\left[\AA^{3}\right]$ & $384(1)$ & 382.9 & $384(1)$ & $382.9(6)$ \\
\hline
\end{tabular}

to sengiérite, ideally $\mathrm{Cu}_{2}\left(\mathrm{UO}_{2}\right)_{2}\left(\mathrm{~V}_{2} \mathrm{O}_{8}\right)(\mathrm{OH})_{2}\left(\mathrm{H}_{2} \mathrm{O}\right)_{6}$ (Piret et al. 1980). The unit-cell parameters obtained from the XRD data (Tab. 12) match those of Piret et al. (1980) (Tab. 13); however, the calculated errors on refined parameters are considerably influenced by the broadening of the diffraction peaks. Even though the Xray diffraction seemed to be fairly straightforward, the EMPA suggested a more complex situation (Tab. 14). The aggregates are represented by a phase: $\left(\mathrm{Cu}_{0.3} \mathrm{Ca}_{0.23}\right.$ $\left.\mathrm{Fe}_{0.03}\right)_{\Sigma 1.19}\left(\mathrm{UO}_{2}\right)_{2.00}\left[\left(\mathrm{~V}_{2} \mathrm{O}_{8}\right)_{0.89}\left(\mathrm{SiO}_{4}\right)_{0.09}\left(\mathrm{SO}_{4}\right)_{0.07}\right]_{\Sigma 1.94}(\mathrm{OH})_{0.54}^{.23}$ 
Tab. 9 Diffraction pattern of soddyite

\begin{tabular}{|c|c|c|c|c|c|c|c|c|c|c|c|}
\hline $\mathrm{I}_{\mathrm{obs}}$ & $\mathrm{d}_{\mathrm{obs}}$ & $\mathrm{d}_{\text {calc }}$ & $\mathrm{h}$ & $\mathrm{k}$ & l & $\mathrm{I}_{\mathrm{obs}}$ & $\mathrm{d}_{\mathrm{obs}}$ & $\mathrm{d}_{\text {calc }}$ & $\mathrm{h}$ & $\mathrm{k}$ & $l$ \\
\hline 80 & 6.287 & 6.285 & 1 & 1 & 1 & 20 & 2.095 & 2.095 & 3 & 3 & 3 \\
\hline 38 & 4.810 & 4.810 & 0 & 2 & 2 & 7 & 2.076 & 2.075 & 4 & 0 & 0 \\
\hline 13 & 4.668 & 4.664 & 0 & 0 & 4 & 15 & 2.047 & 2.047 & 1 & 5 & 3 \\
\hline 98 & 4.550 & 4.550 & 1 & 1 & 3 & 18 & 1.9795 & 1.9797 & 1 & 1 & 9 \\
\hline 16 & 3.790 & 3.792 & 2 & 0 & 2 & 19 & 1.9104 & 1.9110 & 3 & 3 & 5 \\
\hline 45 & 3.361 & 3.356 & 1 & 3 & 1 & 8 & 1.8922 & 1.8921 & 3 & 1 & 7 \\
\hline 100 & 3.340 & 3.338 & 2 & 2 & 0 & 32 & 1.8616 & 1.8622 & 2 & 4 & 6 \\
\hline 28 & 3.257 & 3.257 & 1 & 1 & 5 & 1 & 1.8344 & 1.8348 & 0 & 6 & 2 \\
\hline 31 & 2.991 & 2.991 & 1 & 3 & 3 & 2 & 1.7937 & 1.7938 & 0 & 4 & 8 \\
\hline 21 & 2.806 & 2.807 & 0 & 4 & 0 & 8 & 1.7716 & 1.7716 & 1 & 3 & 9 \\
\hline 60 & 2.719 & 2.720 & 0 & 2 & 6 & 4 & 1.7358 & 1.7361 & 3 & 5 & 1 \\
\hline 6 & 2.657 & 2.659 & 3 & 1 & 1 & 13 & 1.7054 & 1.7060 & 2 & 6 & 0 \\
\hline 5 & 2.521 & 2.518 & 1 & 3 & 5 & 12 & 1.6801 & 1.6789 & 3 & 5 & 3 \\
\hline 20 & 2.489 & 2.489 & 2 & 0 & 6 & 14 & 1.6686 & 1.6688 & 4 & 4 & 0 \\
\hline 30 & 2.473 & 2.475 & 1 & 1 & 7 & 18 & 1.6511 & 1.6499 & 4 & 2 & 6 \\
\hline 18 & 2.469 & 2.466 & 3 & 1 & 3 & 11 & 1.6469 & 1.6466 & 2 & 4 & 8 \\
\hline 3 & 2.402 & 2.405 & 0 & 4 & 4 & 8 & 1.6030 & 1.6034 & 0 & 6 & 6 \\
\hline 10 & 2.330 & 2.332 & 0 & 0 & 8 & 5 & 1.5876 & 1.5879 & 5 & 1 & 3 \\
\hline 3 & 2.282 & 2.275 & 2 & 2 & 6 & 3 & 1.5546 & 1.5547 & 0 & 0 & 12 \\
\hline 16 & 2.256 & 2.256 & 2 & 4 & 2 & 5 & 1.5273 & 1.5267 & 1 & 7 & 3 \\
\hline 9 & 2.208 & 2.209 & 3 & 3 & 1 & 8 & 1.5165 & 1.5167 & 3 & 3 & 9 \\
\hline 4 & 2.178 & 2.180 & 3 & 1 & 5 & 4 & 1.4738 & 1.4744 & 5 & 3 & 3 \\
\hline 3 & 2.153 & 2.153 & 1 & 5 & 1 & & & & & & \\
\hline
\end{tabular}

$\left(\mathrm{H}_{2} \mathrm{O}\right)_{n}$ (mean of 3 analyses, on the basis of $2 \mathrm{U} a p f u$, which is close to idealized formula, $\mathrm{Cu}\left(\mathrm{UO}_{2}\right)_{2} \mathrm{~V}_{2} \mathrm{O}_{8}\left(\mathrm{H}_{2} \mathrm{O}\right)_{n}$ (Fig. 7). We do not know whether these point analyses belong to sengiérite and are affected by the high porosity or the poor surface of the polished section, etc.), and/or by the nature of the mineral itself (e.g., the occupational and positional disorder at the $\mathrm{Cu}$ site). Alternatively, the analyzed phase may belong to a possible new $\mathrm{Cu}$-analogue of tyuyamunite.

4.2.8. Uranopilite, $\left[\left(\mathrm{UO}_{2}\right)_{6}\left(\mathrm{SO}_{4}\right)\right.$
$\left.\mathrm{O}_{2}(\mathrm{OH})_{6}\left(\mathrm{H}_{2} \mathrm{O}\right)_{6}\right]\left(\mathrm{H}_{2} \mathrm{O}\right)_{8}$

Uranopilite occurs usually somewhat separated from other uranyl-sulfate minerals. It forms typical crystalline aggregates composed of hundreds of tiny long-prismatic crystals of intense lemon yellow to pale greenish-yellow color. The aggregates reach up to 0.5 $\mathrm{cm}$ across and commonly grow in the

Tab. 10 Refined unit-cell parameters for soddyite from Jáchymov (for the orthorhombic space group Fddd)

\begin{tabular}{lrc}
\hline & $\begin{array}{c}\text { Jáchymov, } \\
\text { this paper }\end{array}$ & $\begin{array}{c}\text { Zaire, } \\
\text { Demartin et al. (1992) }\end{array}$ \\
\hline$a[\AA]$ & $8.301(2)$ & $8.334(2)$ \\
$b[\AA]$ & $11.229(2)$ & $11.212(5)$ \\
$c[\AA]$ & $18.657(4)$ & $18.668(6)$ \\
$V\left[\AA^{3}\right]$ & $1731.1(7)$ & $1744(1)$ \\
\hline
\end{tabular}

fractures of the ore-specimens (Fig. 8a).

The chemical composition of uranopilite studied is near the ideal formula. Its empirical formula is (mean of 5 analyses, on the basis of $\mathrm{U}+\mathrm{Si}+\mathrm{S}=$ 7 apfu) $\left[\left(\mathrm{UO}_{2}\right)_{5.91}\left\{\left(\mathrm{SO}_{4}\right)_{0.92}\left(\mathrm{SiO}_{4}\right)_{0.17}\right\}_{\Sigma 1.09} \mathrm{O}_{2}(\mathrm{OH})_{5.30}\right.$ $\left.\left(\mathrm{H}_{2} \mathrm{O}\right)_{6}\right]\left(\mathrm{H}_{2} \mathrm{O}\right)_{8}$ (Tab. 15). Interesting is $\mathrm{Si}$ entering the $T$-site in low concentrations, which is in agreement with previously observed similar behavior in case of uranylphosphates (entering of $\mathrm{Si}$ ) or silicates (entering of $\mathrm{P} / \mathrm{As}$ ) (e.g., Plášil et al. 2009, 2010).

The single-crystal diffraction experiment (Tab. 16) showed triclinic unit cell (space group $P \overline{1})$ with $a=8.8556(9), b=$ $13.9819(15), c=14.307(3)$ $\AA, \alpha=96.749(12)^{\circ}, \beta=$ $98.754(12)^{\circ}, \gamma=99.726(9)^{\circ}$ and $V=1706.9(4) \AA^{3}$ (Tab. 17). The quality of the data is much affected by the pervasive twinning of the crystals with many overlapping reflections; the

Fig. 7 Plot of $\mathrm{Ca}+\mathrm{Mg}+\mathrm{Al}+\mathrm{Ba}+$ $\mathrm{Y}+\mathrm{Fe}$ vs. $\mathrm{Cu}$ contents (apfu) for uranyl vanadates from the Červená vein, Jáchymov (calculation of apfu on the basis of $2 \mathrm{U}$ atoms).

$\mathrm{Ca}+\mathrm{Mg}+\mathrm{Al}+\mathrm{Ba}+\mathrm{Y}+\mathrm{Fe}(\mathrm{apfu})$ 
unresolved twinning artifacts together with the poor absorption correction are responsible for the high positive difference Fourier peaks, located in the very vicinity of $U$ atoms within the uranopilite sheet. Also the limited resolution of the data convolutes to the Fourier artifacts. The problems with twinning and thus the data-quality were also encountered by previous structure determinations (Burns 2001; Meisser 2012) (see Tab. 17). The structure of uranopilite from the Črvená vein was refined from the data to an $R_{1}=0.0923$ for 1849 unique observed reflections with $\left[I_{\text {obs }}>3 \sigma(I)\right]$ and fully confirms the previous structure determination by Burns (2001). The CIF file, containing also a block with the reflections, is deposited at the Journal's web page www.jgeosci.org.
Tab. 11 Chemical composition of tyuyamunite (in wt.\%)

\begin{tabular}{|c|c|c|c|c|c|c|c|}
\hline & mean & 1 & 2 & 3 & 4 & 5 & 6 \\
\hline $\mathrm{MgO}$ & 0.13 & 0.23 & 0.30 & bdl & 0.07 & 0.07 & 0.11 \\
\hline $\mathrm{CaO}$ & 5.69 & 5.22 & 4.92 & 5.80 & 5.76 & 5.87 & 6.55 \\
\hline $\mathrm{Al}_{2} \mathrm{O}_{3}$ & 0.10 & 0.04 & 0.13 & 0.00 & 0.15 & 0.10 & 0.17 \\
\hline $\mathrm{BaO}$ & 0.21 & 0.44 & 0.17 & 0.37 & 0.15 & 0.10 & 0.17 \\
\hline $\mathrm{Y}_{2} \mathrm{O}_{3}$ & 0.14 & 0.43 & 0.25 & bdl & bdl & 0.17 & bdl \\
\hline $\mathrm{SiO}_{2}$ & 0.87 & 1.45 & 0.39 & 0.57 & 0.82 & 1.08 & 0.89 \\
\hline $\mathrm{SO}_{3}$ & 0.22 & 0.00 & 0.21 & 0.33 & 0.21 & 0.43 & 0.16 \\
\hline $\mathrm{V}_{2} \mathrm{O}_{5}$ & 18.60 & 19.03 & 18.94 & 18.08 & 18.24 & 18.31 & 18.99 \\
\hline $\mathrm{UO}_{3}$ & 63.73 & 64.48 & 65.13 & 64.15 & 62.93 & 61.49 & 64.20 \\
\hline Total & 89.69 & 91.32 & 90.43 & 89.30 & 88.33 & 87.52 & 91.21 \\
\hline $\mathrm{Mg}$ & 0.029 & 0.051 & 0.065 & & 0.016 & 0.015 & 0.023 \\
\hline $\mathrm{Ca}$ & 0.910 & 0.825 & 0.771 & 0.921 & 0.934 & 0.974 & 1.040 \\
\hline $\mathrm{Al}$ & 0.017 & 0.007 & 0.022 & 0.000 & 0.027 & 0.018 & 0.029 \\
\hline $\mathrm{Ba}$ & 0.012 & 0.025 & 0.010 & 0.021 & 0.009 & 0.000 & 0.009 \\
\hline Y & 0.011 & 0.034 & 0.019 & & & 0.014 & \\
\hline$\Sigma M^{2+}$ & 0.979 & 0.942 & 0.887 & 0.942 & 0.986 & 1.121 & 1.081 \\
\hline $\mathrm{SiO}_{4}$ & 0.129 & 0.215 & 0.057 & 0.085 & 0.124 & 0.168 & 0.132 \\
\hline $\mathrm{SO}_{4}$ & 0.025 & 0.000 & 0.023 & 0.036 & 0.024 & 0.050 & 0.018 \\
\hline $\mathrm{VO}_{4}$ & 1.836 & 1.856 & 1.829 & 1.773 & 1.823 & 1.873 & 1.861 \\
\hline$\Sigma T$ site & 1.990 & 2.071 & 1.911 & 1.894 & 1.971 & 2.091 & 2.011 \\
\hline $\mathrm{UO}_{2}{ }^{2+}$ & 2.000 & 2.000 & 2.000 & 2.000 & 2.000 & 2.000 & 2.000 \\
\hline
\end{tabular}

Calculation on the basis of $\mathrm{U}=2$ apfu
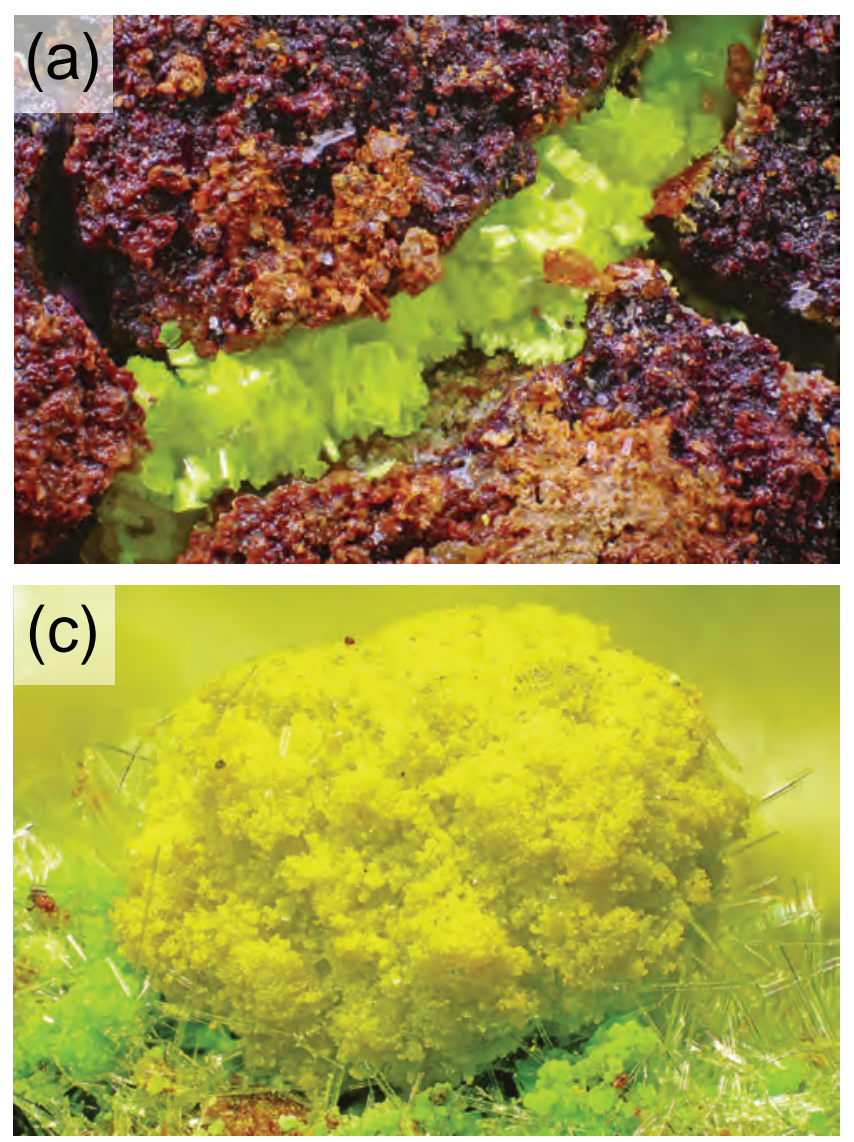

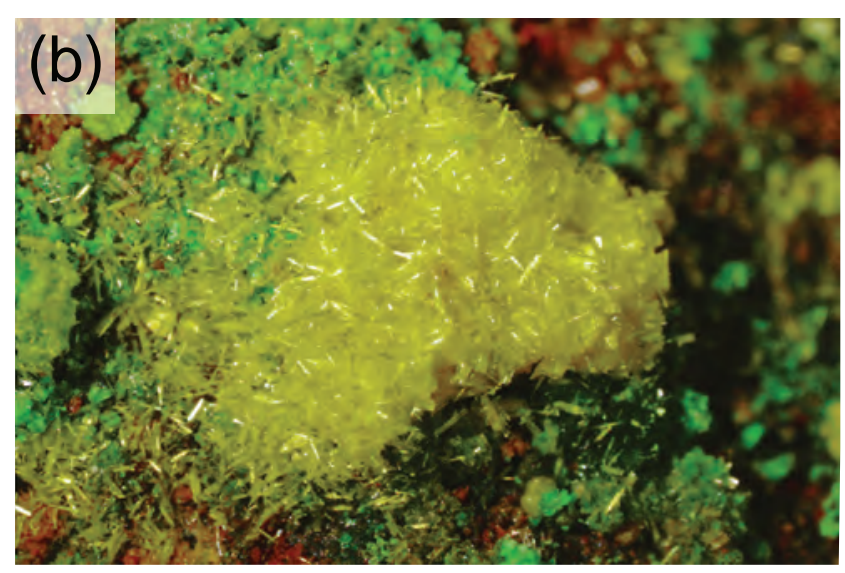

Fig. 8 Supergene uranyl-sulfates from Červená vein. a - Uranopilite crystals growing in the fracture of ore-specimen consisting of disseminated uraninite and massive sulphides (chalcopyrite). Width of image $3.5 \mathrm{~mm}$. $\mathbf{b}$ - Long-prismatic crystals of the unnamed $\mathrm{Cu}$ uranyl-sulfate with brochantite (greenish) and pseudojohannite (grass-green). Width of image $4.6 \mathrm{~mm}$. c - The Cu-bearing marécottite (sulphuric yellow) with cuprosklodowskite (light green) and acicular gypsum crystals on altered ore-bearing specimen. Width of image $3.5 \mathrm{~mm}$. 
Tab. 12 Powder diffraction data for sengierite from the Červená vein, Jáchymov $\left(d_{h k l}\right.$ values in $\AA$ )

\begin{tabular}{|c|c|c|c|c|c|c|}
\hline $\mathrm{I}_{\mathrm{obs}}$ & $\mathrm{d}_{\mathrm{obs}}$ & $\mathrm{d}_{\text {calc }}$ & $\mathrm{I}_{\text {calc }}$ & h & $\mathrm{k}$ & l \\
\hline 44 & 9.69 & 9.77 & 47 & 0 & 0 & 1 \\
\hline 7 & 6.48 & 6.37 & 20 & 1 & 1 & 0 \\
\hline 9 & 5.71 & 5.71 & $0^{*}$ & -1 & 1 & 1 \\
\hline 20 & 5.15 & 5.16 & 17 & 2 & 0 & 0 \\
\hline 32 & 5.09 & 5.03 & 17 & 1 & 1 & 1 \\
\hline 16 & 4.88 & 4.89 & 100 & 0 & 0 & 2 \\
\hline 30 & 4.30 & 4.35 & 65 & 2 & 1 & 0 \\
\hline 35 & 4.26 & 4.29 & 68 & -2 & 1 & 1 \\
\hline 48 & 4.14 & 4.16 & 14 & -1 & 1 & 2 \\
\hline 46 & 4.06 & 4.03 & 25 & -2 & 0 & 2 \\
\hline 23 & 3.74 & 3.74 & 65 & 0 & 2 & 1 \\
\hline 15 & 3.65 & 3.61 & 5 & -1 & 2 & 1 \\
\hline 50 & 3.26 & 3.26 & 27 & 0 & 0 & 3 \\
\hline 73 & 3.21 & 3.21 & 12 & -3 & 1 & 1 \\
\hline 58 & 3.18 & 3.18 & 41 & 2 & 2 & 0 \\
\hline 50 & 3.16 & 3.17 & 62 & 3 & 1 & 0 \\
\hline 36 & 3.11 & 3.11 & 80 & 0 & 2 & 2 \\
\hline 40 & 3.08 & 3.11 & 63 & -1 & 2 & 2 \\
\hline 10 & 3.03 & 3.02 & 8 & 0 & 1 & 3 \\
\hline 7 & 2.969 & 2.981 & 23 & 2 & 1 & 2 \\
\hline 5 & 2.962 & 2.950 & 34 & -3 & 1 & 2 \\
\hline 6 & 2.865 & 2.882 & 54 & -2 & 1 & 3 \\
\hline 1 & 2.823 & 2.854 & 13 & -2 & 2 & 2 \\
\hline 4 & 2.655 & 2.647 & 17 & -4 & 0 & 1 \\
\hline 2 & 2.618 & 2.621 & 17 & 3 & 2 & 0 \\
\hline 6 & 2.573 & 2.569 & 21 & -1 & 2 & 3 \\
\hline 8 & 2.561 & 2.556 & 20 & -1 & 3 & 1 \\
\hline 10 & 2.544 & 2.536 & 7 & 0 & 2 & 3 \\
\hline 6 & 2.459 & 2.459 & 16 & 4 & 1 & 0 \\
\hline 2 & 2.394 & 2.389 & 33 & 2 & 3 & 0 \\
\hline 1 & 2.378 & 2.379 & 14 & -2 & 3 & 1 \\
\hline
\end{tabular}

Refined unit-cell parameters from powder-diffraction data are similar to the published ones (Tab. 19).

$$
\begin{aligned}
& \text { 4.2.10. Unnamed Cu-uranyl-sulfate, } \mathrm{Cu}_{2} \\
& {\left[\left(\mathrm{UO}_{2}\right)_{4}\left(\mathrm{SO}_{4}\right)_{3}\right](\mathrm{OH})_{6}\left(\mathrm{H}_{2} \mathrm{O}\right)_{\mathrm{n}}}
\end{aligned}
$$

New unnamed $\mathrm{Cu}$-uranyl-sulfate was found along with the $\mathrm{Cu}$-rich pseudojohannite, pseudojohannite and sejkoraite-(Y). It forms long prismatic crystals of greenish sulfuric-yellow color resembling uranopilite, only much longer (Fig. 8b). According to EMPA, it is the $\mathrm{Cu}$-dominant uranyl-sulfate but differing from all known minerals by the U-S ratio of $4: 3$. The chemical composition (Tab. 20) can be expressed by the empirical formula $\left(\mathrm{Cu}_{1.36} \mathrm{Mg}_{0.31} \mathrm{Na}_{0.09} \mathrm{Zn}_{0.09}\right)_{\sum 1.85}\left[\left(\mathrm{UO}_{2}\right)_{4.00}\left\{\left(\mathrm{SO}_{4}\right)_{2.90}\right.\right.$ $\left.\left.\left(\mathrm{SiO}_{4}\right)_{0.15}\right\}_{\sum 3.05}\right](\mathrm{OH})_{5.23}\left(\mathrm{H}_{2} \mathrm{O}\right)_{n}$ (mean of 6 point analyses on the basis of $4 \mathrm{U}$ apfu). The whole group of crystals was destroyed for the microprobe analysis. Attempts to find more of this phase in order to collect the powder XRD data remained unsuccessful.

\subsubsection{Zippeite-group minerals}

$\mathrm{Cu}$-bearing marécottite, $(\mathrm{Mg}, \mathrm{Cu})_{3}\left[\left(\mathrm{UO}_{2}\right)_{4} \mathrm{O}_{3}(\mathrm{OH})\right.$ $\left(\mathrm{SO}_{4}\right)_{2} \mathrm{~J}_{2}\left(\mathrm{H}_{2} \mathrm{O}\right)_{28}$, is a phase that we have designated like that, based on the EPMA results. It forms rich finely crystalline aggregates of the sulfuric to greenish yellow color reaching up to $0.5 \mathrm{~cm}$ (Fig. 8c). Aggregates of Cu-bearing marécottite are composed of minute crystals, character-

\begin{tabular}{|c|c|c|c|c|c|c|c|}
\hline Mineral & Locality & Reference & $a[\AA]$ & $b[\AA]$ & $c[\AA]$ & $\beta\left[^{\circ}\right]$ & $V\left[\AA^{3}\right]$ \\
\hline Sengiérite & Červená vein & this paper & $10.61(4)$ & $8.09(3)$ & $10.04(5)$ & $102.98(5)$ & $840(6)$ \\
\hline Sengiérite & Luiwishi mine, Congo & Piret et al. (1980) & $10.599(5)$ & $8.093(4)$ & $10.085(9)$ & $103.42(6)$ & 841.5 \\
\hline
\end{tabular}

Tab. 13 Unit cell parameters of sengiérite (for monoclinic space group $\mathrm{P} 2_{1} / a$ )

\subsubsection{Metazeunerite, $\mathrm{Cu}\left[\left(\mathrm{UO}_{2}\right)_{2}\left[\left(\mathrm{AsO}_{4}\right)_{2}\right]\right.$ $\left(\mathrm{H}_{2} \mathrm{O}\right)_{6}$}

Metazeunerite was locally found forming crystalline to poorly crystalline aggregates, with appearance of fluidallike structures. It has green to light green color and imperfect crystals reach up to $1 \mathrm{~mm}$ in size. Metazeunerite was not found in association of any other uranyl mineral. It grows directly on a strongly altered surface of an orebearing specimen.

The metazeunerite from the Červená vein is nearly pure $\mathrm{Cu}$-member only with a small portion of $\mathrm{Fe}$ (up to $0.08 \mathrm{Fe}$ $a p f u$ ) and Co (up to $0.03 \mathrm{Co} a p f u$ ) entering the cationic site (Tab. 18). However, interesting are the low $\mathrm{SO}_{4}$ contents (up to $0.08 \mathrm{~S}$ apfu) detected besides dominant $\mathrm{AsO}_{4}$ (1.87-1.97 As apfu) and $\mathrm{PO}_{4}$ (up to 0.03 P apfu). Empirical formula of the studied metazeunerite is (mean of 3 analyses, $\mathrm{Cu}+\mathrm{Fe}+\mathrm{Co}+\mathrm{S}+\mathrm{P}+\mathrm{As}+\mathrm{U}=5 \mathrm{apfu})\left(\mathrm{Cu}_{0.97} \mathrm{Fe}_{0.07}\right.$ $\left.\mathrm{Co}_{0.02}\right)_{\Sigma 1.06}\left(\mathrm{UO}_{2}\right)_{1.95}\left[\left(\mathrm{AsO}_{4}\right)_{1.92}\left(\mathrm{SO}_{4}\right)_{0.05}\left(\mathrm{PO}_{4}\right)_{0.03}\right]_{\Sigma 2.00}\left(\mathrm{H}_{2} \mathrm{O}\right)_{6}$.
Tab. 14 Chemical composition of an unnamed "CuUVO phase" (in wt. \%)

\begin{tabular}{lcccc}
\hline & Mean & 1 & 2 & 3 \\
\hline $\mathrm{CaO}$ & 1.31 & 1.28 & 1.14 & 1.51 \\
$\mathrm{CuO}$ & 7.56 & 7.47 & 8.70 & 6.52 \\
$\mathrm{FeO}$ & 0.24 & 0.38 & 0.21 & 0.14 \\
$\mathrm{SO}_{3}$ & 0.57 & 0.74 & 0.62 & 0.35 \\
$\mathrm{SiO}_{2}$ & 0.55 & 0.55 & 0.77 & 0.34 \\
$\mathrm{~V}_{2} \mathrm{O}_{5}$ & 16.54 & 16.60 & 16.44 & 16.58 \\
$\mathrm{UO}_{3}$ & 58.44 & 59.37 & 57.81 & 58.15 \\
\hline $\mathrm{Total}$ & 85.21 & 86.38 & 85.68 & 83.58 \\
\hline $\mathrm{Ca}$ & 0.228 & 0.219 & 0.202 & 0.265 \\
$\mathrm{Cu}$ & 0.931 & 0.905 & 1.082 & 0.806 \\
$\mathrm{Fe}$ & 0.032 & 0.051 & 0.028 & 0.019 \\
$\Sigma A_{\text {site }}$ & 1.191 & 1.175 & 1.312 & 1.090 \\
\hline $\mathrm{SO}_{4}$ & 0.070 & 0.089 & 0.076 & 0.043 \\
$\mathrm{SiO}_{4}$ & 0.090 & 0.087 & 0.127 & 0.055 \\
$\mathrm{VO}_{4}$ & 1.780 & 1.758 & 1.789 & 1.794 \\
$\Sigma T$ site & 1.940 & 1.934 & 1.992 & 1.892 \\
\hline $\mathrm{UO}_{2}$ & 2.000 & 2.000 & 2.000 & 2.000 \\
\hline $\mathrm{Calu}$ & & & &
\end{tabular}

Calculation on the basis of $U=2$ apfu 
istic of the zippeite-like minerals (Fig. 10a). The Cu-bearing marécottite is closely associated with cuprosklodowskite and it on-grows the strongly altered surface of the uraninite-bearing specimens along with gypsum crystals.

The chemical composition can be expressed by the empirical formula (mean of 3 analyses, on the basis of $8 \mathrm{U}$ apfu $):\left(\mathrm{Mg}_{0.75} \mathrm{Cu}_{0.71} \mathrm{Ca}_{0.33}\right.$ $\mathrm{Mn}_{0.20} \mathrm{Ba}_{0.18} \mathrm{Zn}_{0.09} \mathrm{Ni}_{0.05} \mathrm{Al}_{0.05}$ $\left.\mathrm{Na}_{0.03} \mathrm{Co}_{0.02} \mathrm{~K}_{0.02}\right)_{\Sigma 2.43}\left[\left(\mathrm{UO}_{2}\right)_{8.00} \mathrm{O}_{6}\right.$ $\left.(\mathrm{OH})_{1.07}\left\{\left(\mathrm{SO}_{4}\right)_{3.55}\left(\mathrm{SiO}_{4}\right)_{0.14}\left(\mathrm{AsO}_{4}\right)_{0.03}\right\}_{53.72}\right]\left(\mathrm{H}_{2} \mathrm{O}\right)_{28}$ ( Tab. 21). The water content was assumed to be equal to the ideal one determined by the crystal structure refinement (Brugger et al. 2003), i.e. that needed for the charge-balance. As we can see, the low-valence cationic site is characterized by deficiency in occupancy (Fig. 9). However, this is not an unusual phenomenon among uranyl-sulfates, especially of the zippeite group (Plášil et al. 2011a, b; Števko et al. 2012; Plášil et al. 2013b).

The powder XRD experiments are challenging, because the $\mathrm{Cu}$-rich marécottite dehydrates quickly after grinding to a powder. Therefore the data acquisition had to be fast. The obtained data allowed us to refine the unit-cell parameters giving reasonable results, similar to the published data. The unit-cell parameters were refined based on the Rietveld refinement algorithm, whereby the crystal structure parameters of Brugger et al. (2003) were used as the starting model. The refined unitcell parameters compare well to the earlier published data (Tab. 22). An additional phase was detected in the XRD pattern but not identified with certainty; a few diffractions unassigned to marécottite partially match the expected peaks of magnesiozippeite.

Data collection

Diffractometer

Temperature [K]

Radiation, wavelength $[\AA]$

Limiting Miller indices

Total reflections collected

Unique reflections

Unique reflections, criterion

Data/restraints/parameters

$R_{1}$ obs, $w R_{2}$ obs

$R_{1}$ all, $w R_{2}$ all

GOF obs/all

Weighting scheme, weights

Twin fractions

Twinning matrix 1,$2 ; 1,3$
Tab. 15 Chemical composition of uranopilite from the vein Červená (in wt. \%)

\begin{tabular}{lccccrr}
\hline & Mean & 1 & 2 & 3 & \multicolumn{1}{c}{4} & 5 \\
\hline $\mathrm{SiO}_{2}$ & 0.49 & 0.41 & 0.45 & 0.52 & 0.77 & 0.33 \\
$\mathrm{SO}_{3}$ & 3.61 & 3.90 & 3.19 & 3.64 & 3.58 & 3.74 \\
$\mathrm{UO}_{3}$ & 82.59 & 83.02 & 81.71 & 83.48 & 82.51 & 82.23 \\
$\mathrm{H}_{2} \mathrm{O}^{*}$ & 14.65 & 14.78 & 14.44 & 14.81 & 14.61 & 14.63 \\
\hline $\mathrm{Total}$ & 101.35 & 102.11 & 99.79 & 102.45 & 101.47 & 100.93 \\
\hline $\mathrm{SiO}_{4}$ & 0.168 & 0.138 & 0.157 & 0.173 & 0.258 & 0.113 \\
$\mathrm{SO}_{4}$ & 0.922 & 0.986 & 0.838 & 0.921 & 0.904 & 0.963 \\
$\Sigma T$ site & 1.090 & 1.124 & 0.996 & 1.094 & 1.161 & 1.076 \\
$\mathrm{UO}_{2}$ & 5.910 & 5.876 & 6.004 & 5.906 & 5.839 & 5.924 \\
$\mathrm{OH}$ & 5.303 & 5.228 & 5.702 & 5.276 & 4.839 & 5.471 \\
$\mathrm{H}_{2} \mathrm{O}$ & 14 & 14 & 14 & 14 & 14 & 14 \\
\hline
\end{tabular}

calculation on the basis of $\mathrm{U}+\mathrm{Si}+\mathrm{S}=7$ apfu

$\mathrm{H}_{2} \mathrm{O} *$ - water content in wt. \% derived from the ideal $14 \mathrm{H}_{2} \mathrm{O}$ in the crystal structure of uranopilite

Pseudojohannite, $\mathrm{Cu}_{3}(\mathrm{OH})_{2}\left[\left(\mathrm{UO}_{2}\right)_{4} \mathrm{O}_{4}\left(\mathrm{SO}_{4}\right)_{2}\right]\left(\mathrm{H}_{2} \mathrm{O}\right)_{12}$, and its $\mathrm{Cu}$-rich variety. Although pseudojohannite was identified as less abundant mineral species in the studied association, it forms rich crystalline aggregates composed

Tab. 16 Crystallographic data and refinement details for uranopilite from the Červená vein

\begin{tabular}{ll}
\hline Crystal data & \\
Ideal formula & {$\left[\left(\mathrm{UO}_{2}\right)_{6}\left(\mathrm{SO}_{4}\right) \mathrm{O}_{2}(\mathrm{OH})_{6}\left(\mathrm{H}_{2} \mathrm{O}\right)_{6}\right]\left(\mathrm{H}_{2} \mathrm{O}\right)_{8}$} \\
Crystal system & triclinic \\
Space group & $P \overline{1}$ \\
Unit-cell parameters: $a, b, c[\AA]$ & $8.8556(9), 13.9819(15), 14.307(3)$ \\
$\alpha, \beta, \gamma\left[^{\circ}\right]$ & $96.749(12), 98.754(12), 99.726(9)$ \\
Unit-cell volume $\left[\AA^{3}\right]$ & $1706.9(4)$ \\
$Z$ & 2 \\
Calculated density $\left[\mathrm{g} / \mathrm{cm}^{3}\right]$ & 3.992 \\
Absorption coefficient $\left[\mathrm{mm}^{-1}\right]$, type & 28.33 \\
Crystal size $[\mathrm{mm}]$ & $0.15 \times 0.05 \times 0.03$
\end{tabular}

$\theta$ range for data collection $\left[^{\circ}\right]$

Axis, frame width $\left(^{\circ}\right)$, time per frame (s)

Data completeness to $\theta_{\text {max }}(\%), R_{\text {int }}$

Structure refinement by Jana2006

No. of refined parameters, restraints

Largest diff. peak and hole $\left(\mathrm{e}^{-} / \AA^{3}\right)$

Oxford Diffraction Gemini with Atlas detector

301

$\mathrm{MoK}_{\alpha}, 0.71073$

2.84-29.46

$h=-10 \rightarrow 11, k=-16 \rightarrow 17, l=-18 \rightarrow 16$

$\omega, 0.5,120$

17839

7496

$1849,[I>3 \sigma(I)]$

$97.78,0.158$

Full-matrix least-squares on $F^{2}$

214, 0

$511 / 2 / 65$

$0.0923,0.1886$

$0.2687,0.2719$

$1.65,1.15$

$\sigma, w=1 /\left(\sigma^{2}(I)+0.0004 I^{2}\right)$

$0.57(2) / 0.37(2) / 0.06(2)$

$14.93,-7.84$

$\left(\begin{array}{ccc}1.013 & -0.060 & 0.023 \\ 0.046 & 1 & -0.020 \\ -0.011 & 0.044 & 0.986\end{array}\right)$,




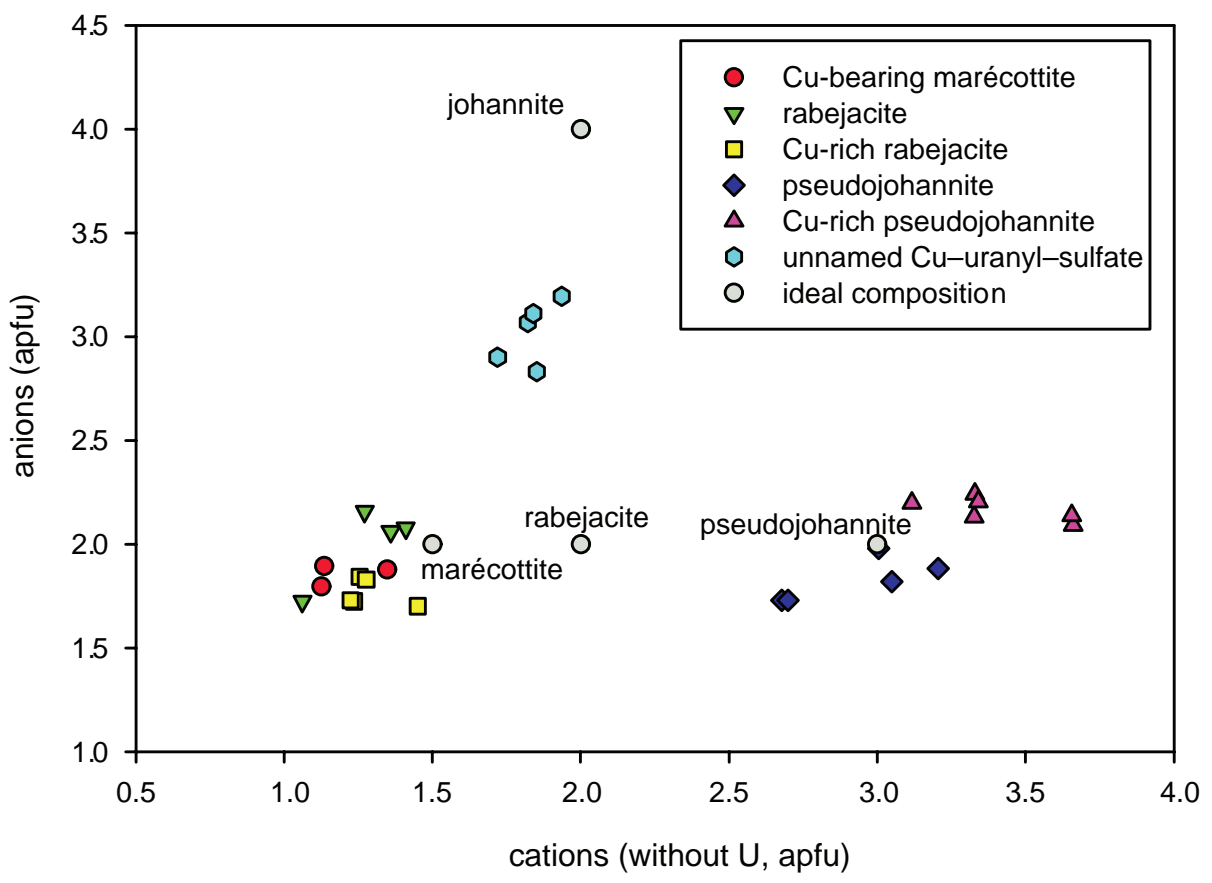

Fig. 9 Plot of cations (without U) vs. anions contents $(p f u)$ for selected uranyl-sulfates from the Červená vein (calculation of apfu on the basis $4 \mathrm{U}$ atoms).

Tab. 17 Comparison of the unit-cell parameters for uranopilite from various occurrences (for the triclinic space group $P-1$ )

\begin{tabular}{|c|c|c|c|c|c|c|c|c|c|c|c|c|c|}
\hline Locality & Method & Reference & $R_{\mathrm{int}}$ & $\mathrm{UR}^{\dagger}$ & $R_{1}$ & $\mathrm{UR}^{\ddagger}$ & $a[\AA]$ & $b[\AA]$ & $c[\AA]$ & $\alpha\left[^{\circ}\right]$ & $\beta\left[^{\circ}\right]$ & $\gamma\left[^{\circ}\right]$ & $V\left[\AA^{3}\right]$ \\
\hline Jách & $\mathrm{SC}$ & this & 0.158 & 7496 & 0.0923 & 1849 & 8.8556 & $13.982(2)$ & 14.307( & $96.75(1)$ & 98.75 & 99.726 & \\
\hline áchy & $\mathrm{SC}$ & Burns & & & 0.07 & 3907 & $8.896(2)$ & $14.029(3)$ & $14.339(3)$ & 96.61 & 98.472 & 4) & \\
\hline $\mathrm{CaC}$ & $\mathrm{SC}$ & Meiss & 0.298 & 3313 & 0.1173 & 3098 & $8.901(2)$ & $14.042(3)$ & $14.521(3)$ & $97.41(3)$ & $98.97(3)$ & $99.69(3)$ & $1744.4(6)$ \\
\hline říbram & powder & Plášil & & & & & $8.896(6)$ & $14.025(9)$ & $14.299(6)$ & $96.68(4)$ & $98.60(6)$ & $99.92(6)$ & 1719(2) \\
\hline ř́íbram & powder & Sejkora et al. (2004) & & & & & $8.857(6)$ & $13.975(8)$ & $14.335(4)$ & $96.70(4)$ & $98.63(4)$ & $99.56(6)$ & 1711(2) \\
\hline
\end{tabular}

$\mathrm{SC}$ - single crystal data; $\mathrm{UR}^{\dagger}-$ number of all unique reflections; $\mathrm{UR}^{\ddagger}-$ number of reflections with $[I>3 \sigma(I)]$ (this paper) or $[I>4 \sigma(I)]($ Burns 2001; Brugger unpublished data).

of minute crystals. According to SEM, the pseudojohannite crystals are long prismatic and form multiple intergrowths (Fig. 10b). Aggregates have apple to grass green color and strong glassy luster and reach exceptionally up to $8 \mathrm{~mm}$ in size (Fig. 11a). Only on one specimen, the pseudojohannite was found to be in crystals up to 0.2 $\mathrm{mm}$ across in association with cuprosklodowksite, $\mathrm{Cu}-$ compreignacite (type III) and amorphous $\mathrm{Cu}$-containing phases (Fig. 11b). Pseudojohannite is usually associated with other uranyl-sulfates - uranopilite, rabejacite and brochantite.

Chemical composition of studied pseudojohannite is fairly homogeneous (Tab. 23). It can be expressed by the empirical formula $\left(\mathrm{Cu}_{2.91} \mathrm{Mg}_{0.01}\right)_{\Sigma 2.92}$ $\left[\left(\mathrm{UO}_{2}\right)_{4.00} \mathrm{O}_{4}\left(\left(\mathrm{SO}_{4}\right)_{1.82}\left(\mathrm{SiO}_{4}\right)_{0.03}\right)_{\Sigma 1.85}\right](\mathrm{OH})_{2.09}\left(\mathrm{H}_{2} \mathrm{O}\right)_{12}$ (mean of 5 analyses, calculated on the basis of $4 \mathrm{U}$ apfu). Interestingly, even if $\mathrm{Cu}^{2+}$ content varies only a little from the ideal stoichiometry, we observed another phase occurring with pseudojohannite, with distinct $\mathrm{Cu}^{2+}$ content (Fig. 9). Although the crystal morphology resembles pseudojohannite, a more detailed description and characterization is lacking, because the crystals in the polished section represent the only available material. Because of the higher $\mathrm{Cu}$
Tab. 18 Chemical composition of metazeunerite from the Červená vein (in wt. \%)

\begin{tabular}{lcccc}
\hline & Mean & 1 & 2 & 3 \\
\hline $\mathrm{CuO}$ & 8.35 & 8.55 & 8.34 & 8.16 \\
$\mathrm{FeO}$ & 0.52 & 0.45 & 0.51 & 0.60 \\
$\mathrm{CoO}$ & 0.16 & 0.09 & 0.15 & 0.24 \\
$\mathrm{SO}_{3}$ & 0.44 & 0.38 & 0.23 & 0.70 \\
$\mathrm{P}_{2} \mathrm{O}_{5}$ & 0.19 & 0.18 & 0.23 & 0.16 \\
$\mathrm{As}_{2} \mathrm{O}_{5}$ & 23.90 & 23.70 & 24.82 & 23.19 \\
$\mathrm{UO}_{3}$ & 82.59 & 83.02 & 81.71 & 83.48 \\
$\mathrm{H}_{2} \mathrm{O}^{*}$ & 11.72 & & & \\
\hline $\mathrm{Total}$ & 105.80 & 93.90 & 95.23 & 93.10 \\
\hline $\mathrm{Cu}$ & 0.968 & 0.999 & 0.955 & 0.951 \\
$\mathrm{Fe}$ & 0.067 & 0.058 & 0.065 & 0.077 \\
$\mathrm{Co}$ & 0.020 & 0.011 & 0.018 & 0.030 \\
$\Sigma \mathrm{A}$ site & 1.055 & 1.068 & 1.038 & 1.058 \\
\hline $\mathrm{SO}_{4}$ & 0.050 & 0.044 & 0.026 & 0.081 \\
$\mathrm{PO}_{4}$ & 0.025 & 0.024 & 0.030 & 0.021 \\
$\mathrm{AsO}_{4}$ & 1.918 & 1.919 & 1.966 & 1.869 \\
$\Sigma T$ site & 1.993 & 1.987 & 2.122 & 1.971 \\
$\mathrm{UO}_{2}$ & 1.952 & 1.944 & 1.941 & 1.971 \\
$\mathrm{H}_{2} \mathrm{O}$ & 6 & & & \\
\hline
\end{tabular}

calculation on the basis $\mathrm{Cu}+\mathrm{Fe}+\mathrm{Co}+\mathrm{S}+\mathrm{P}+\mathrm{As}+\mathrm{U}=5$ apfu $\mathrm{H}_{2} \mathrm{O}^{*}$ - water content in wt. \% derived from the ideal $6 \mathrm{H}_{2} \mathrm{O}$ in the crystal structure of metazeunerite 

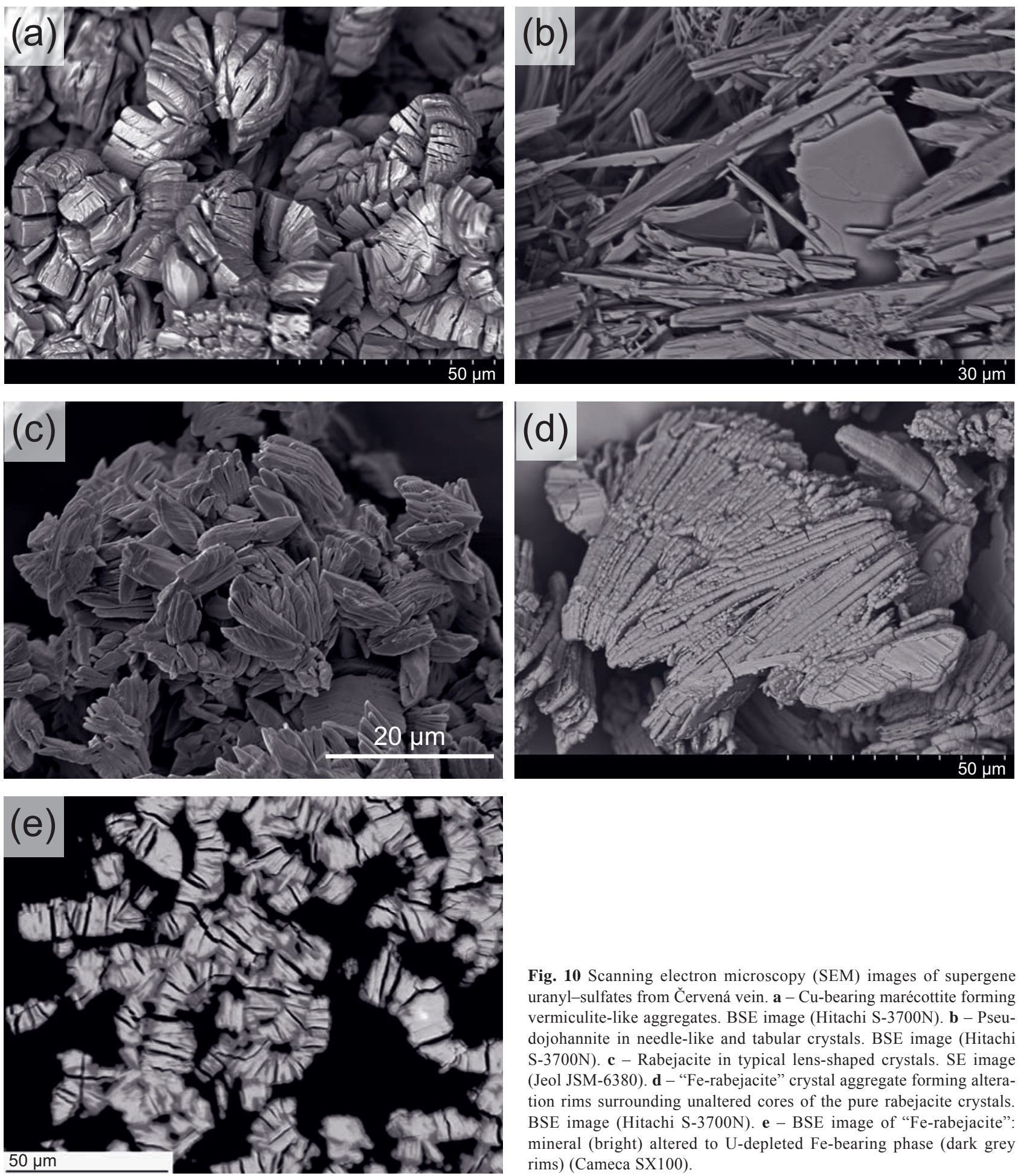

content, proven by EMPA, we termed the phase $\mathrm{Cu}^{2+}$-rich pseudojohannite (Tab. 24), whose chemical composition is: $\left(\mathrm{Cu}_{3.38} \mathrm{Mg}_{0.02} \mathrm{Fe}_{0.01}\right)_{\Sigma 3.41}\left[\left(\mathrm{UO}_{2}\right)_{4.00} \mathrm{O}_{4}\left\{\left(\mathrm{SO}_{4}\right)_{1.82}\left(\mathrm{SiO}_{4}\right)_{0.12}\right\}_{\Sigma 1.94}\right]$ $(\mathrm{OH})_{2.23}\left(\mathrm{H}_{2} \mathrm{O}\right)_{\mathrm{n}}$ (calculated as the mean of 6 point analyses on the basis of $4 \mathrm{U} a p f u$ ).

The full structure description for pseudojohannite was recently published by Plášil et al. (2012a). Still,

Fig. 10 Scanning electron microscopy (SEM) images of supergene uranyl-sulfates from Červená vein. $\mathbf{a}-\mathrm{Cu}$-bearing marécottite forming vermiculite-like aggregates. BSE image (Hitachi S-3700N). b - Pseudojohannite in needle-like and tabular crystals. BSE image (Hitachi S-3700N). c - Rabejacite in typical lens-shaped crystals. SE image (Jeol JSM-6380). d - "Fe-rabejacite" crystal aggregate forming alteration rims surrounding unaltered cores of the pure rabejacite crystals. BSE image (Hitachi S-3700N). e - BSE image of "Fe-rabejacite": mineral (bright) altered to U-depleted Fe-bearing phase (dark grey rims) (Cameca SX100).

the new powder diffraction data using proper $h k l$ indices according to the new structure data are lacking so far. Therefore, we present the new powder-diffraction data here (Tab. 25). The refined unit cell from the powder data along with the unit-cell parameters from the preliminary single-crystal X-ray diffraction data are listed in Tab. 26. 

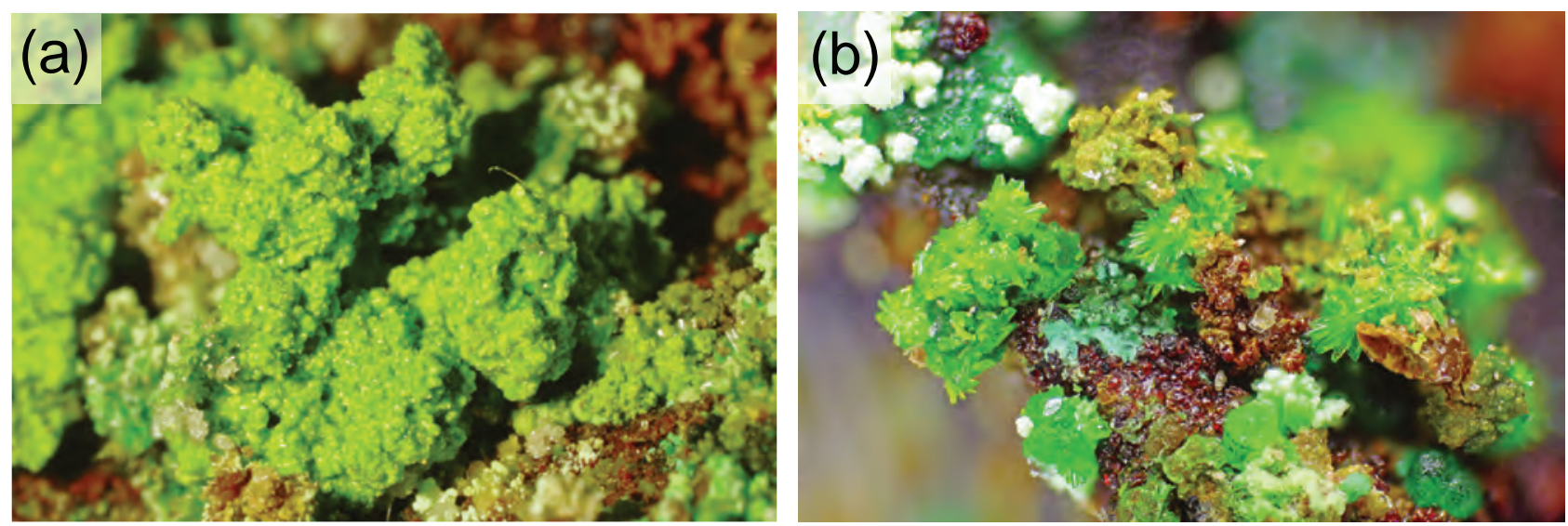

Fig. 11a - Powder aggregates of pseudojohannite. Width of image $4.6 \mathrm{~mm}$. b - Pseudojohannite crystals (bright green) with brochantite (sea green), cuprosklodowskite (white with greenish tint; upper left) and amorphous Cu-phases. Width of image $3.2 \mathrm{~mm}$.

Rabejacite, $\mathrm{Ca}_{2}\left[\left(\mathrm{UO}_{2}\right)_{4} \mathrm{O}_{4}\left(\mathrm{SO}_{4}\right)_{2}\right]\left(\mathrm{H}_{2} \mathrm{O}\right)_{9}$ and its $\mathrm{Cu}^{2+}$ and $\mathrm{Fe}^{2+/ 3+}$ varieties. Rabejacite is a relatively abundant phase. It forms usually finely crystalline aggregates and coatings, of the yellow or orange-yellow color (Fig. 12a). Aggregates consist of lens-shaped crystals, reaching only several microns across (Fig. 10c). Less common are crystalline aggregates composed of inconspicuous scattered larger $(0.3-0.5 \mathrm{~mm})$ crystals of orange or yellowish-orange

Tab. 19 Refined unit-cell parameters for metazeunerite (for the tetragonal space group $P 4 / n n c$ )

\begin{tabular}{lcc}
\hline & $\begin{array}{l}\text { Červená vein, } \\
\text { this paper }\end{array}$ & $\begin{array}{l}\text { Synthetic, } \\
\text { Locock and Burns (2003) }\end{array}$ \\
\hline$a[\AA]$ & $7.150(8)$ & $7.1797(3)$ \\
$b[\AA]$ & $20.8333(5)$ & $20.857(1)$ \\
$V\left[\AA^{3}\right]$ & $1065.1(1)$ & $1075.1(1)$ \\
\hline
\end{tabular}

color (Fig. 12b). These crystals however reach up to $0.3-0.5 \mathrm{~mm}$ across. Rabejacite occurs usually in a close association with „Fe-rabejacite“, uranopilite and gypsum on the strongly altered surface of the gangue. The chemical composition (Tab. 27) can be expressed by the empirical formula (as the mean of 4 individual analyses on the basis of $4 \mathrm{U}$ apfu $):\left[\left(\mathrm{Ca}_{1.12} \mathrm{Ba}_{0.02}\right)_{\Sigma 1.14}\left(\mathrm{Cu}_{0.10} \mathrm{Fe}_{0.02} \mathrm{Zn}_{0.02}\right)_{\Sigma 0.14}\right]_{\Sigma 1.28}$ $\left(\mathrm{UO}_{2}\right)_{4}\left[\left(\mathrm{SO}_{4}\right)_{1.95}\left(\mathrm{SiO}_{4}\right)_{0.05}\right]_{22.00} \mathrm{O}_{3.19} \cdot 8 \mathrm{H}_{2} \mathrm{O}$. The $\mathrm{O}^{2-}$ content was calculated by charge balance, and it is significantly lower than the ideal content of $4 \mathrm{O}$ apfu present in the ideal formula $\left[\left(\mathrm{UO}_{2}\right)_{4} \mathrm{O}_{4}\left(\mathrm{SO}_{4}\right)\right]$. This is caused by the decrease in the occupancy of the cationic sites (Fig. 9) dominated, according to the EMPA, by $\mathrm{Ca}^{2+}$ and $\mathrm{Cu}^{2+}$. Here we anticipate some recent results of the structure study of rabejacite, which are a subject of a forthcoming specialized paper. According to the single-crystal X-ray diffraction, the two different cationic sites can be distinguished in the rabejacite structure. First one, where the cations are coordinated by a higher number of ligands $(\sim 7)$, is populated by $\mathrm{Ca}^{2+}$ and also probably by other similar elements (e.g. Ba, Sr). The second site of the studied samples contains $\mathrm{Cu}^{2+}$, and probably also $\mathrm{Fe}$ and $\mathrm{Zn}$ (see further $\mathrm{Cu}^{2+}$-rabejacite). This site is [5]-coordinated by ligands including $\mathrm{O}$ and molecular $\mathrm{H}_{2} \mathrm{O}$. This coordination is not very characteristic of $\mathrm{Zn}^{2+}$ or $\mathrm{Fe}^{2+}$, which typically prefer an octahedral coordination. Regardless, we conclude that increasing concentrations of these elements should lead to the occurrence of the [6]-coordination.

Coefficients of the empirical formulae were calculated on the basis of $4 \mathrm{U}$ apfu $\mathrm{OH}^{\$}$ - derived from the charge-balance 
Tab. 21 Chemical composition of Cu-marécottite (in wt. \%)

\begin{tabular}{|c|c|c|c|c|c|}
\hline & Ideal & Mean & 1 & 2 & 3 \\
\hline $\mathrm{Na}_{2} \mathrm{O}$ & & 0.03 & bdl & 0.09 & bdl \\
\hline $\mathrm{K}_{2} \mathrm{O}$ & & 0.03 & 0.05 & bdl & 0.03 \\
\hline $\mathrm{MnO}$ & & 0.45 & 0.40 & 0.51 & 0.44 \\
\hline $\mathrm{CaO}$ & & 0.60 & 0.48 & 0.75 & 0.58 \\
\hline $\mathrm{MgO}$ & 3.74 & 0.99 & 1.01 & 1.04 & 0.92 \\
\hline $\mathrm{Al}_{2} \mathrm{O}_{3}$ & & 0.08 & 0.12 & bdl & 0.11 \\
\hline $\mathrm{BaO}$ & & 0.90 & 0.93 & 0.93 & 0.84 \\
\hline $\mathrm{CuO}$ & & 1.85 & 1.39 & 1.93 & 2.23 \\
\hline $\mathrm{CoO}$ & & 0.05 & 0.15 & bdl & bdl \\
\hline $\mathrm{NiO}$ & & 0.13 & bdl & 0.25 & 0.15 \\
\hline $\mathrm{ZnO}$ & & 0.24 & 0.36 & 0.36 & bdl \\
\hline $\mathrm{As}_{2} \mathrm{O}_{5}$ & & 0.10 & 0.07 & 0.17 & 0.06 \\
\hline $\mathrm{SiO}_{2}$ & & 0.27 & 0.24 & 0.44 & 0.14 \\
\hline $\mathrm{SO}_{3}$ & 9.91 & 9.36 & 8.93 & 9.10 & 10.05 \\
\hline $\mathrm{UO}_{3}$ & 70.77 & 75.30 & 73.93 & 74.49 & 77.50 \\
\hline $\mathrm{H}_{2} \mathrm{O}$ & 15.60 & 16.92 & 16.62 & 16.80 & 17.35 \\
\hline Total & 100.02 & 107.30 & 104.69 & 106.86 & 110.37 \\
\hline $\mathrm{Na}$ & & 0.028 & - & 0.084 & - \\
\hline $\mathrm{K}$ & & 0.018 & 0.035 & 0.018 & 0.000 \\
\hline $\mathrm{Mn}$ & & 0.192 & 0.174 & 0.221 & 0.182 \\
\hline $\mathrm{Ca}$ & & 0.325 & 0.264 & 0.408 & 0.303 \\
\hline $\mathrm{Mg}$ & & 0.745 & 0.777 & 0.790 & 0.670 \\
\hline $\mathrm{Al}$ & & 0.045 & 0.074 & - & 0.064 \\
\hline $\mathrm{Ba}$ & & 0.179 & 0.186 & 0.186 & 0.163 \\
\hline $\mathrm{Cu}$ & & 0.707 & 0.542 & 0.745 & 0.828 \\
\hline $\mathrm{Co}$ & & 0.020 & 0.060 & - & - \\
\hline $\mathrm{Ni}$ & 2.998 & 0.055 & - & 0.104 & 0.059 \\
\hline $\mathrm{Zn}$ & & 0.090 & 0.137 & 0.137 & \\
\hline$\Sigma A$ site & 2.998 & 2.404 & 2.252 & 2.695 & 2.269 \\
\hline $\mathrm{AsO}_{4}$ & & 0.027 & 0.019 & 0.045 & 0.016 \\
\hline $\mathrm{SiO}_{4}$ & & 0.137 & 0.124 & 0.222 & 0.068 \\
\hline $\mathrm{SO}_{4}$ & 4.000 & 3.553 & 3.453 & 3.491 & 3.707 \\
\hline$\Sigma T$ site & & 3.717 & 3.596 & 3.758 & 3.792 \\
\hline $\mathrm{UO}_{2}{ }^{2+}$ & 8.003 & 8.000 & 8.000 & 8.000 & 8.000 \\
\hline $\mathrm{OH}$ & & 1.073 & 1.083 & 1.281 & 0.865 \\
\hline $\mathrm{H}_{2} \mathrm{O}$ & 27.999 & 28.00 & 28.00 & 28.00 & 28.00 \\
\hline
\end{tabular}

calculation on the basis of $8 \mathrm{U}$ apfu

$\mathrm{H}_{2} \mathrm{O}^{*}$ - obtained based on the presence of $28 \mathrm{H}_{2} \mathrm{O}$ in ideal formula and $\mathrm{OH}$ content inferred from the charge balance

Ideal - calculated for the ideal formula given by Brugger et al. (2003)

Another unusual mineral phase - " $\mathrm{Cu}^{2+}$-rabejacite" forms crystal aggregates composed of tabular crystals of greenish yellow to light green color that reach up to $0.5 \mathrm{~mm}$ (Fig. 12c). It has strong glassy luster and a perfect cleavage. This phase was found only on two specimens and thus the amount of material available is limited. It closely associates with sejkoraite-(Y), zippeite and cuprosklodowskite. The chemical composition of the $\mathrm{Cu}^{2+}$-rabejacite is provided in Tab. 28. The empirical formula of rabejacite expressed as the mean of 4 individual analyses (based on $4 \mathrm{U}$ apfu) is: $\left[\left(\mathrm{Cu}_{0.55} \mathrm{Fe}_{0.04} \mathrm{Mg}_{0.04}\right)_{\Sigma 0.63}\left(\mathrm{Ca}_{0.38} \mathrm{Y}_{0.17} \mathrm{~K}_{0.09} \mathrm{Ba}_{0.05}\right)_{\Sigma 0.69}\right]_{\Sigma 1.32}$ $\left(\mathrm{UO}_{2}\right)_{4}\left[\left(\mathrm{SO}_{4}\right)_{1.54}\left(\mathrm{SiO}_{4}\right)_{0.12}\left(\mathrm{VO}_{4}\right)_{0.12}\right]_{\Sigma 1.78} \mathrm{O}_{3.41} \cdot 8 \mathrm{H}_{2} \mathrm{O}$.
The lower calculated $\mathrm{O}^{2-}$ content (inferred from the chargebalance) is caused by the decrease in the occupancy of the cationic sites (Fig. 9). In case of the studied fragment, $\mathrm{Cu}^{2+}$ prevails at the cationic sites over $\mathrm{Ca}^{2+}$ and, remarkably, also $\mathrm{Y}^{3+}$. This suggests a possible existence of a new $\mathrm{Cu}^{2+}-$ dominant member of the zippeite group, different from pseudojohannite. The presence of $\mathrm{Y}^{3+}$, occupying probably the ${ }^{[7]} \mathrm{Ca}$ site, is not surprising, since the $\mathrm{Y}^{3+}$-dominant member of the zippeite group, sejkoraite-(Y), was described by Plášil et al. (2011a) from the same samples as used in the current study.

The so-called "Fe-rabejacite" (Fig. 12a), usually occurs along with rabejacite and differs from the yellowish rabejacite by its more orange or brownish-orange tint. The powder XRD pattern of this phase is very similar to that of rabejacite. According to qualitative EDS analyses, the main constituents are $\mathrm{U}, \mathrm{S}, \mathrm{O}, \mathrm{Fe}>\mathrm{Ca}$. Finally, the SEM (Fig. 10d) and BSE (Fig. 10e) images revealed that the surface of the rabejacite crystals is covered by a thin alteration crust, probably partially amorphous phase. Backscattered electron image clearly shows that the surface area is depleted in heavy elements compared to the center of the crystals. This suggests release of $\mathrm{UO}_{2}^{2+}$ from the surface layer and replacement by $\mathrm{Fe}$ (most probably as $\mathrm{Fe}^{3+}$ ).

The single-crystal XRD study of rabejacite is complicated, since it forms mostly powder aggregates which do not contain any suitable crystals. During the current work, several crystals of rabejacite and so-called Cu-rabejacite were found and used for the single-crystal X-ray diffraction study. The preliminary results, already cited above, suggested that rabejacite is triclinic and belongs to the space group $P \overline{1}$, with $a=8.7434(11), b=8.309$ (3), $c=8.8693(10) \AA, \alpha=77.86(2)^{\circ}, \beta=104.635(11)^{\circ}$, $\gamma=82.935(18)^{\circ}$, and $V=598.8(3) \AA^{3}$. However synchrotron powder diffraction experiments suggested an additional periodicity caused by very weak diffractions $\left(d_{\text {obs }}\right.$ at $15.69 \AA$ ) doubling the $b$ parameter. No such reflections were observed for single crystals; however, the data are weak and noisy, affected also by a large contribution of the diffusion scattering. The powder data can be fitted by even larger unit cell, with dimensions of $a=8.749(6), b=$ 16.60(1), $c=8.874(6) \AA, \alpha=77.81(5)^{\circ}, \beta=104.68(5)^{\circ}$, $\gamma=82.97(5)^{\circ}, V=1198(1) \AA^{3}$.

Tab. 22 Refined unit-cell parameters of $\mathrm{Cu}$-marécottite (for the triclinic space group $P \overline{1}$ )

\begin{tabular}{lcc}
\hline & $\begin{array}{l}\text { Cu-marécottite, Červená vein } \\
\text { this paper }\end{array}$ & $\begin{array}{l}\text { Marécottite, La Creusaz, Switzerland } \\
\text { Brugger et al. (2003) }\end{array}$ \\
\hline$a[\AA]$ & $10.797(3)$ & $10.815(4)$ \\
$b[\AA]$ & $11.709(3)$ & $11.249(4)$ \\
$c[\AA]$ & $13.621(6)$ & $13.851(6)$ \\
$\alpha\left[^{\circ}\right]$ & $66.37(2)$ & $66.224(7)$ \\
$\beta\left[^{\circ}\right]$ & $72.93(2)$ & $72.412(7)$ \\
$\gamma\left[{ }^{\circ}\right]$ & $69.87(2)$ & $69.955(11)$ \\
$V\left[\AA^{3}\right]$ & $1457(1)$ & $1422.1(9)$ \\
\hline
\end{tabular}



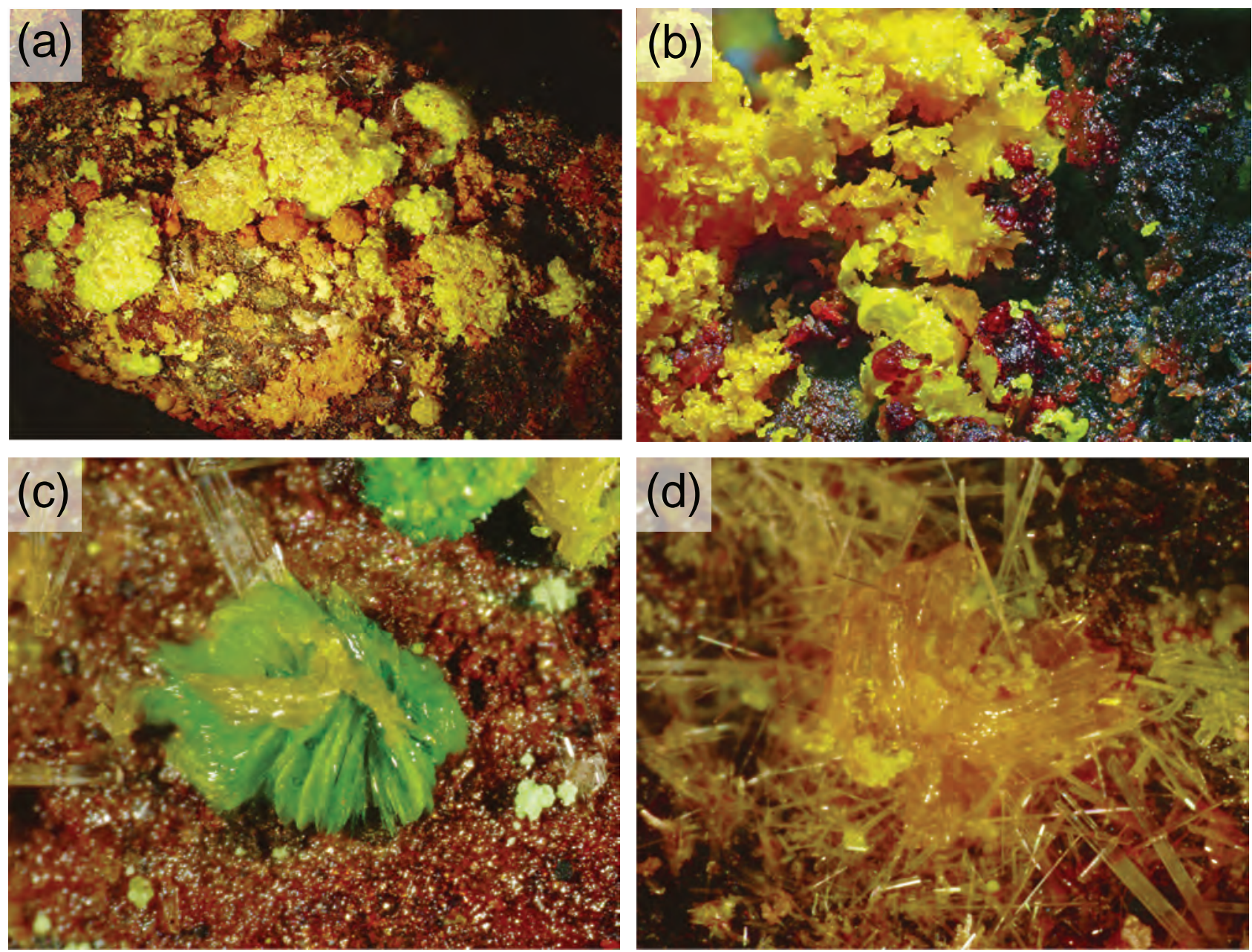

Fig. 12 Rare uranyl-sulfates. a - Rabejacite (yellow), "Fe-rabejacite" (brownish) and uranopilite (sulphuric yellow) on the strongly weathered surface of an ore-bearing specimen. Width of image $30 \mathrm{~mm}$. b - Rabejacite in crystals (center of the picture) in association with lighter yellow, vermiculite-like aggregates of the same mineral. Width of image $3.2 \mathrm{~mm}$. c - Crystals of $\mathrm{Cu}^{2+}$-bearing rabejacite (green) in association with sejkoraite-(Y) (orange). Width of image $2.5 \mathrm{~mm}$. d - Sejkoraite-(Y) on gypsum. Width of image $2 \mathrm{~mm}$.

Sejkoraite- $(\mathrm{Y}), \mathrm{Y}_{3}\left[\left(\mathrm{UO}_{2}\right)_{8} \mathrm{O}_{7} \mathrm{OH}\left(\mathrm{SO}_{4}\right)_{4}\right](\mathrm{OH})_{2}\left(\mathrm{H}_{2} \mathrm{O}\right)_{24}$, is a new mineral phase of the zippeite-group, described from the Červená vein and approved by the CNMNC of the International Mineralogical Association (Plášil et al. 2011a). It is the first zippeite-group mineral that contains trivalent cations. It is triclinic, space group $P \bar{T}$, with $a=14.0743(6), b=17.4174(7), c=17.7062(8)$ $\AA, \alpha=75.933(4), \beta=128.001(5), \gamma=74.419(4)^{\circ}$, and $V=2777.00(19) \AA^{3}, Z=2, D_{\text {calc }}=4.04 \mathrm{~g} \cdot \mathrm{cm}^{-3}$ (Pláśil et al. 2011a). The ideal chemical composition of sejkoraite-( $\mathrm{Y})$ can be expressed by the formula: $\mathrm{Y}_{3}(\mathrm{OH})_{2}\left[\left(\mathrm{UO}_{2}\right)_{8} \mathrm{O}_{7} \mathrm{OH}\left(\mathrm{SO}_{4}\right)_{4}\right]\left(\mathrm{H}_{2} \mathrm{O}\right)_{24}$. Nearly whole suite of REE was detected by electron microprobe. The full analysis is given in the original description (Pláśil et al. 2011a). However, here we present the chondrite (McDonough and Sun 1995) normalized REE pattern (Fig. 2), which was not included in the above-mentioned paper. The normalization shows strong enrichment of medium to heavy REE with a maximum around Dy.
Sejkoraite-(Y) was found only very rarely at the studied site. Still, it forms conspicuous crystalline aggregates up to $1 \mathrm{~mm}$ across composed of well-developed yellow-orange to orange crystals, with a strong vitreous luster (Fig. 12d). Sejkoraite-(Y) was found in the direct association with rabejacite, $\mathrm{Cu}^{2+}$-rabejacite as well as zippeite, pseudojohannite, uranopilite, cuprosklodowskite and gypsum.

Zippeite, $\mathrm{K}_{2}\left[\left(\mathrm{UO}_{2}\right)_{4} \mathrm{O}_{2}\left(\mathrm{SO}_{4}\right)_{2}(\mathrm{OH})_{2}\right]\left(\mathrm{H}_{2} \mathrm{O}\right)_{4}$ occurrences (the $\mathrm{K}^{+}$-dominant member of the group) are limited to a few localities worldwide; more common are the Na(natrozippeite) or $\mathrm{M}^{2+}$-containing (magnesiozippeite) members of the group. At the underground-site studied, $\mathrm{Mg}$ was mostly lacking but $\mathrm{Ca}$ with $\mathrm{K}$ were prominently supplied probably from the dissolved minerals in the nearby basalt dyke. This is likely the reason, why zippeite is relatively abundant at the studied locality. It forms usually orange crystals (Fig. 13a) or aggregates, up to 2 $\mathrm{mm}$ in size. The individual crystals are euhedral, rarely reaching up to $250 \mu \mathrm{m}$ across (Fig. 14a). The size and 
Supergene minerals from the Červená vein, Jáchymov

quality of the crystals enabled a complete crystallographic study (Plášil et al. 2011b). According to single-crystal X-ray diffraction, zippeite is monoclinic, the space group $C 2 / m$, with unitcell parameters $a=8.7802(6)$, $b=13.9903(12), c=8.8630(6)$ $\AA, \beta=104.524(7)^{\circ}$ with the unitcell volume $V=1053.92(12)$ $\AA^{3}$ and the ideal structure formula $\mathrm{K}_{2}\left[\left(\mathrm{UO}_{2}\right)_{4} \mathrm{O}_{2}(\mathrm{OH})_{2}\left(\mathrm{SO}_{4}\right)_{2}\right]$ $\left(\mathrm{H}_{2} \mathrm{O}\right)_{4}(\mathrm{Z}=2)$. According to Plášil et al. (2011b), chemical composition of this zippeite can be expressed by an empirical formula (mean of 4 point analyses, calculated on the basis of $\mathrm{K}+\mathrm{Na}+\mathrm{Ca}+\mathrm{Fe}$ $+\mathrm{Co}+\mathrm{S}+\mathrm{Si}+\mathrm{U}=8$ apfu): $\left(\mathrm{K}_{1.73} \mathrm{Fe}_{0.04} \mathrm{Ca}_{0.02} \mathrm{Na}_{0.02} \mathrm{Co}_{0.01}\right)_{\Sigma 1.82}$ $\left[\left(\mathrm{UO}_{2}\right)_{4.16} \mathrm{O}_{2}(\mathrm{OH})_{1.91}\left\{\left(\mathrm{SO}_{4}\right)_{1.90}\right.\right.$ $\left.\left.\left(\mathrm{SiO}_{4}\right)_{0.13}\right\}_{\Sigma 2.03}\right]\left(\mathrm{H}_{2} \mathrm{O}\right)_{4}$, provid-

ing a rare agreement between the results of the crystal structure refinement and the electron microprobe analysis. There was also identified a probably later precipitating microcrystalline (powdery) zippeite, in places covering the crystalline aggregates of the above-described zippeite (Fig. 13b). Aggregates are composed of minute crystals of the characteristic lenticular shape (Fig. 14b). Powder-diffraction data are similar to the older zippeite. The refined unit-cell parameters are given in Tab. 29.
Tab. 23 Chemical composition of pseudojohannite from the Červená vein (in wt. \%)

\begin{tabular}{|c|c|c|c|c|c|c|}
\hline & Mean & 1 & 2 & 3 & 4 & 5 \\
\hline $\mathrm{MgO}$ & 0.03 & 0.00 & 0.11 & bdl & 0.04 & bdl \\
\hline $\mathrm{CuO}$ & 13.39 & 12.85 & 13.91 & 14.39 & 13.35 & 12.42 \\
\hline $\mathrm{SiO}_{2}$ & 0.11 & 0.00 & 0.41 & 0.00 & 0.14 & bdl \\
\hline $\mathrm{SO}_{3}$ & 8.41 & 8.36 & 8.42 & 8.51 & 8.72 & 8.02 \\
\hline $\mathrm{UO}_{3}$ & 66.16 & 69.00 & 66.69 & 64.57 & 64.33 & 66.19 \\
\hline $\mathrm{H}_{2} \mathrm{O}^{*}$ & 13.59 & & & & & \\
\hline Total & 101.68 & 90.22 & 89.54 & 87.48 & 86.58 & 86.63 \\
\hline $\mathrm{Mg}$ & 0.013 & 0.000 & 0.048 & - & 0.019 & - \\
\hline $\mathrm{Cu}$ & 2.910 & 2.679 & 3.000 & 3.206 & 2.986 & 2.698 \\
\hline$\Sigma M^{2+}$ & 2.923 & 2.679 & 3.048 & 3.206 & 3.005 & 2.698 \\
\hline $\mathrm{SiO}_{4}$ & 0.032 & 0.000 & 0.117 & 0.000 & 0.042 & - \\
\hline $\mathrm{SO}_{4}$ & 1.816 & 1.732 & 1.805 & 1.884 & 1.938 & 1.731 \\
\hline$\Sigma T$ site & 1.848 & 1.732 & 1.822 & 1.884 & 1.980 & 1.731 \\
\hline $\mathrm{UO}_{2}{ }^{2+}$ & 4.000 & 4.000 & 4.000 & 4.000 & 4.000 & 4.000 \\
\hline $\mathrm{OH}^{\$}$ & 2.09 & 1.89 & 2.02 & 2.64 & 1.97 & 1.93 \\
\hline $\mathrm{H}_{2} \mathrm{O}$ & 12.00 & & & & & \\
\hline
\end{tabular}

Coefficients of the empirical formula were calculated on the basis of $4 \mathrm{U}$ apfu

$\mathrm{H}_{2} \mathrm{O}^{*}$ - content of $\mathrm{H}_{2} \mathrm{O}$ in wt. \% calculated based on ideal content of $12 \mathrm{H}_{2} \mathrm{O}$ in the crystal structure structure

$\mathrm{OH}^{\$}$ - derived from the charge-balance there are several important features that make the studied mineralization interesting.

\subsection{The chemical formula of uraninite and its CHIME age}

The chemical composition of the studied uraninite was calculated considering all the $\mathrm{U}$ content analyzed as being $\mathrm{U}^{4+}$ (measured as $\mathrm{UO}_{2}$ ). Since it is to be expected that not all the $U$ is tetravalent, but certain portion should be

\section{Discussion}

Studied weathering association represents a very typical assemblage resulting from the acid-mine drainage (AMD) processes at the uranium deposits dominated by sulfate minerals. Similar alteration associations were described from e.g. La Creusaz, Switzerland (Meisser et al. 2002; Brugger et al. 2003) or Rožná, Czech Republic (Veselovský and Ondruš 2002). Besides the activity of $\mathrm{SO}_{4}{ }^{2-}$, higher than at other known accumulations of the supergene uranyl minerals in Jáchymov (e.g., Ondruš et al. 2003d; Sejkora et al. 2013),
Tab. 24 Chemical composition of the $\mathrm{Cu}$-rich pseudojohannite-like phase from the vein Červená (in wt. \%)

\begin{tabular}{lrrrrrrr}
\hline & Mean & \multicolumn{1}{c}{1} & \multicolumn{1}{c}{2} & \multicolumn{1}{c}{3} & \multicolumn{1}{c}{4} & \multicolumn{1}{c}{5} & \multicolumn{1}{c}{6} \\
\hline $\mathrm{MgO}$ & 0.04 & 0.00 & 0.09 & 0.00 & 0.06 & 0.00 & 0.08 \\
$\mathrm{CuO}$ & 15.78 & 17.65 & 16.72 & 15.35 & 14.56 & 14.67 & 15.73 \\
$\mathrm{FeO}$ & 0.04 & 0.03 & 0.02 & 0.12 & 0.02 & 0.05 & 0.00 \\
$\mathrm{SiO}_{2}$ & 0.43 & 0.35 & 0.48 & 0.60 & 0.46 & 0.19 & 0.50 \\
$\mathrm{SO}_{3}$ & 9.62 & 9.72 & 9.36 & 9.59 & 9.81 & 9.73 & 9.46 \\
$\mathrm{UO}_{3}$ & 67.13 & 69.49 & 66.73 & 66.28 & 67.66 & 68.86 & 65.74 \\
\hline $\mathrm{Total}$ & 93.03 & 97.24 & 93.40 & 91.93 & 92.56 & 91.49 & 91.54 \\
\hline $\mathrm{Mg}$ & 0.017 & 0.000 & 0.048 & 0.000 & 0.019 & 0.000 & 0.000 \\
$\mathrm{Cu}$ & 3.381 & 3.653 & 3.603 & 3.300 & 3.094 & 3.316 & 3.341 \\
$\mathrm{Fe}$ & 0.009 & 0.007 & 0.005 & 0.028 & 0.004 & 0.011 & 0.000 \\
$\Sigma M^{2+}$ & 3.407 & 3.660 & 3.656 & 3.328 & 3.117 & 3.327 & 3.341 \\
\hline $\mathrm{SiO}_{4}$ & 0.122 & 0.095 & 0.136 & 0.176 & 0.129 & 0.053 & 0.146 \\
$\mathrm{SO}_{4}$ & 1.816 & 1.999 & 2.004 & 2.068 & 2.072 & 2.081 & 2.061 \\
$\Sigma T$ site & 1.938 & 2.094 & 2.140 & 2.244 & 2.201 & 2.134 & 2.207 \\
\hline $\mathrm{UO}_{2}^{2+}$ & 4.000 & 4.000 & 4.000 & 4.000 & 4.000 & 4.000 & 4.000 \\
$\mathrm{OH}^{\$}$ & 2.23 & 2.94 & 2.74 & 1.84 & 1.59 & 1.96 & 2.25 \\
\hline $\mathrm{Coeficis}^{2+}$ & & & & & & &
\end{tabular}

Coefficients of the empirical formula were calculated on the basis of $4 \mathrm{U}$ apfu

$\mathrm{OH}^{\$}$ - derived from the charge-balance (assuming $4 \mathrm{O}$ atoms in the structure unit) 

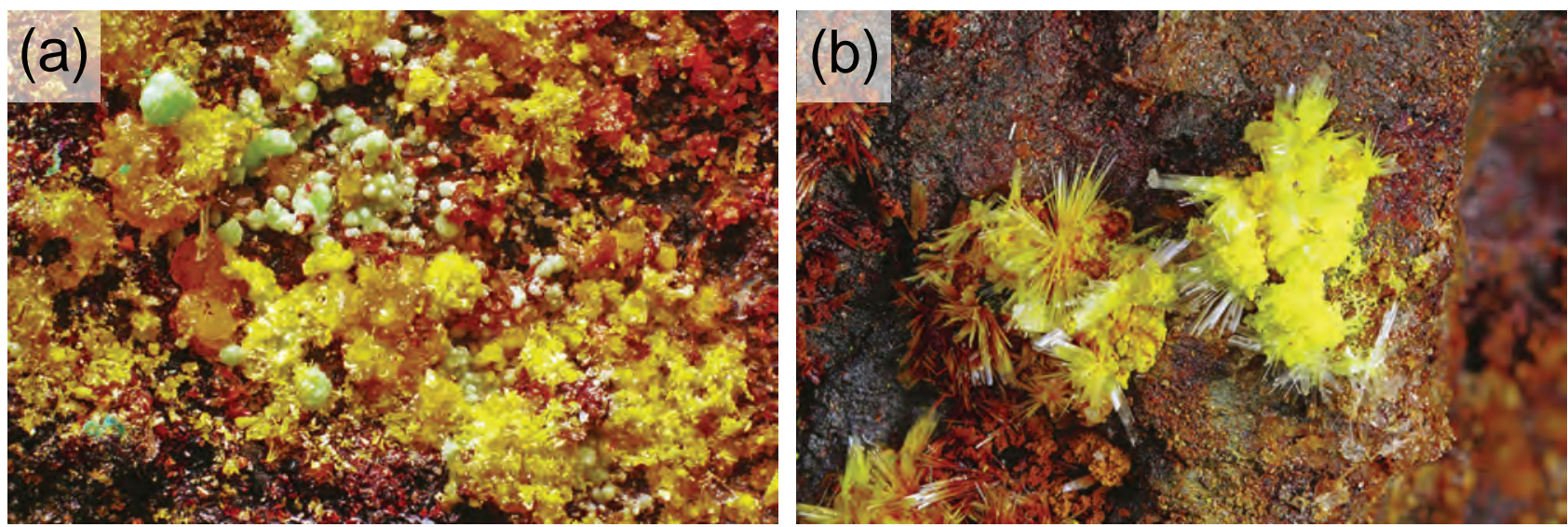

Fig. 13a - Crystal aggregates of zippeite with cuproklodowskite (whitish green). Width of image $3.2 \mathrm{~mm}$. $\mathbf{b}$ - Powder aggregates of zippeite, partly limonitized, with elongated crystals of gypsum on a weathered gangue. Width of image $3.2 \mathrm{~mm}$.

present as $\mathrm{U}^{6+}$, due to the oxidizing weathering of uraninite (Finch and Ewing 1992), and no direct analysis for $\mathrm{U}^{4+} / \mathrm{U}^{6+}$ ratio in analyzed sample is available (as e.g. from X-ray photoelectron spectroscopy), the empirical formula given has only estimentative value. Besides U, the most common elements in the structure of uraninite are $\mathrm{Ca}^{2+}$ and $\mathrm{REE}^{3+}$ (Janeczek and Ewing 1992). The $\mathrm{Ca}^{2+}$ contents in uraninites from various localities vary greatly, from 0.X to first X.0 wt.\%, usually (see e.g., Pearcy et al. 1994; Ondruš et al. 2003a; Deditius et al. 2007a, b; Škácha et al. 2009; Sharpe and Fayek 2011), rarely exceeding 10 wt.\% CaO (R. Škoda, pers. comm., 2014; unpublished data of the authors). Janeczek and Ewing (1992) stated, based on the similarity of ionic radii of elements commonly found in uraninite, that $\mathrm{Ca}^{2+}(1.12 \AA)$ substitutes for $\mathrm{U}^{4+}(1.0 \AA)$, along with $\mathrm{Th}^{4+}(1.05 \AA), \mathrm{Zr}^{4+}$ $(0.84 \AA), \mathrm{Y}^{3+}(1.019 \AA)$ and $\operatorname{REE}^{3+}(0.98-1.16 \AA)$. Recently, two exotic minerals were described rom the northern Caucasus: elbrusite-(Zr) and vorlanite (Galuskina et al. 2010; Galuskin et al. 2011). The former is an U-bearing garnet, where $\mathrm{U}$ (as well as $\mathrm{Ca}$ ) is bounded into highly metamict domains of the crystals. The latter is cubic $(F m \overline{3} m) \mathrm{CaU}^{6+} \mathrm{O}_{4}$, where $\mathrm{U}^{6+}$ and $\mathrm{Ca}^{2+}$ occupy the same site $(50 / 50)$. Since these cations have distinct ionic radii $\left({ }^{[8]} \mathrm{U}^{6+}=0.86 \AA,{ }^{[8]} \mathrm{Ca}^{2+}=1.12 \AA\right)$, vorlanite possesses a highly disordered structure.

The real nature and fate (not only) of $\mathrm{Ca}^{2+}$ in the structure of uraninite remains unknown and its clarification would require precise TEM/HRTEM studies, which, however, would be difficult, for instance due to radiation damage of the crystal lattice. The uraninite from Jáchymov, in general, underwent several hydrothermal events (Ondruš et al. 1997, 2003a, d), also connected with remobilization of elements and, in particular, the radiogenic $\mathrm{Pb}$. Such explanation is also partially supported by the CHIME dating results yielding the age of 154-160 Ma (Tab. 1), which is in accord with the results of Legierski (1973), who provided following model ages on uraninite from Jáchymov: 75, 140, 165, 202, 247 and $285 \mathrm{Ma}$. According to Förster and Haack (1995), uraninite ages for
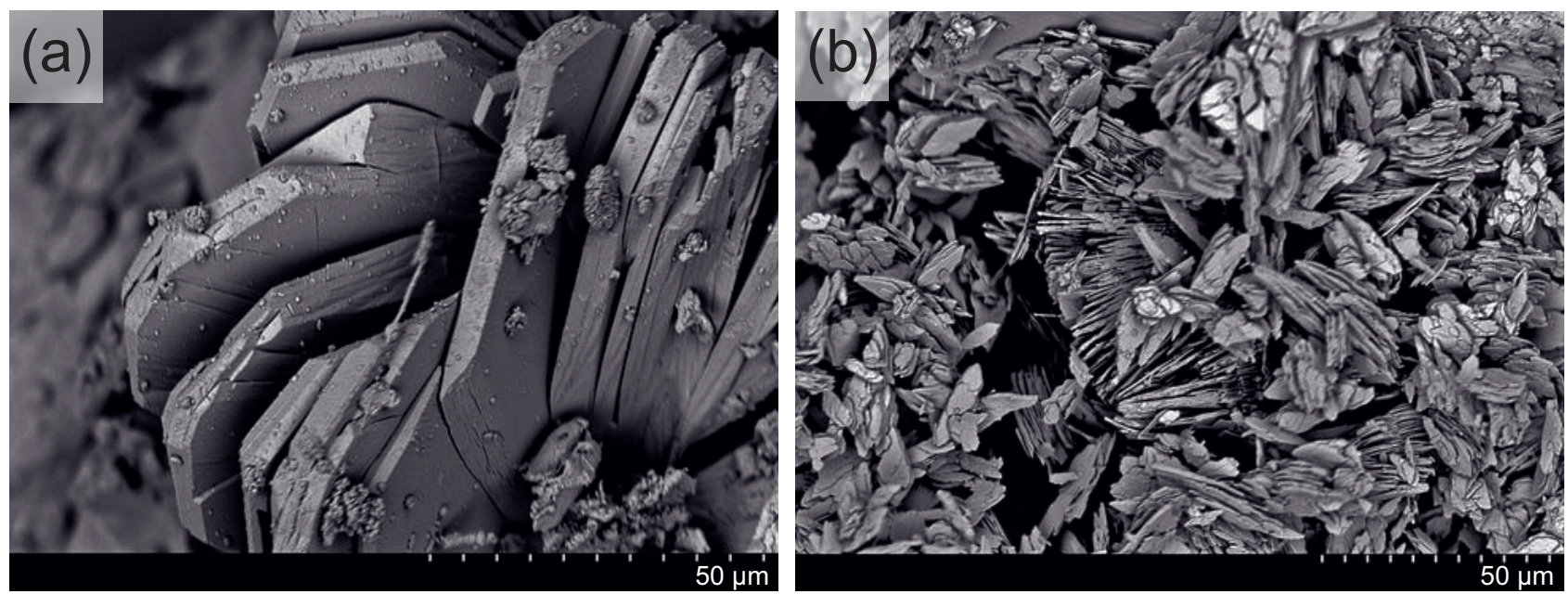

Fig. 14 Scanning electron microscopy (SEM) images of zippeite from Červená vein. a - Multiple generations of zippeite crystals. BSE image (Hitachi S-3700N). b - Fine crystalline aggregates (powdery) of zippeite. BSE image (Hitachi S-3700N). 


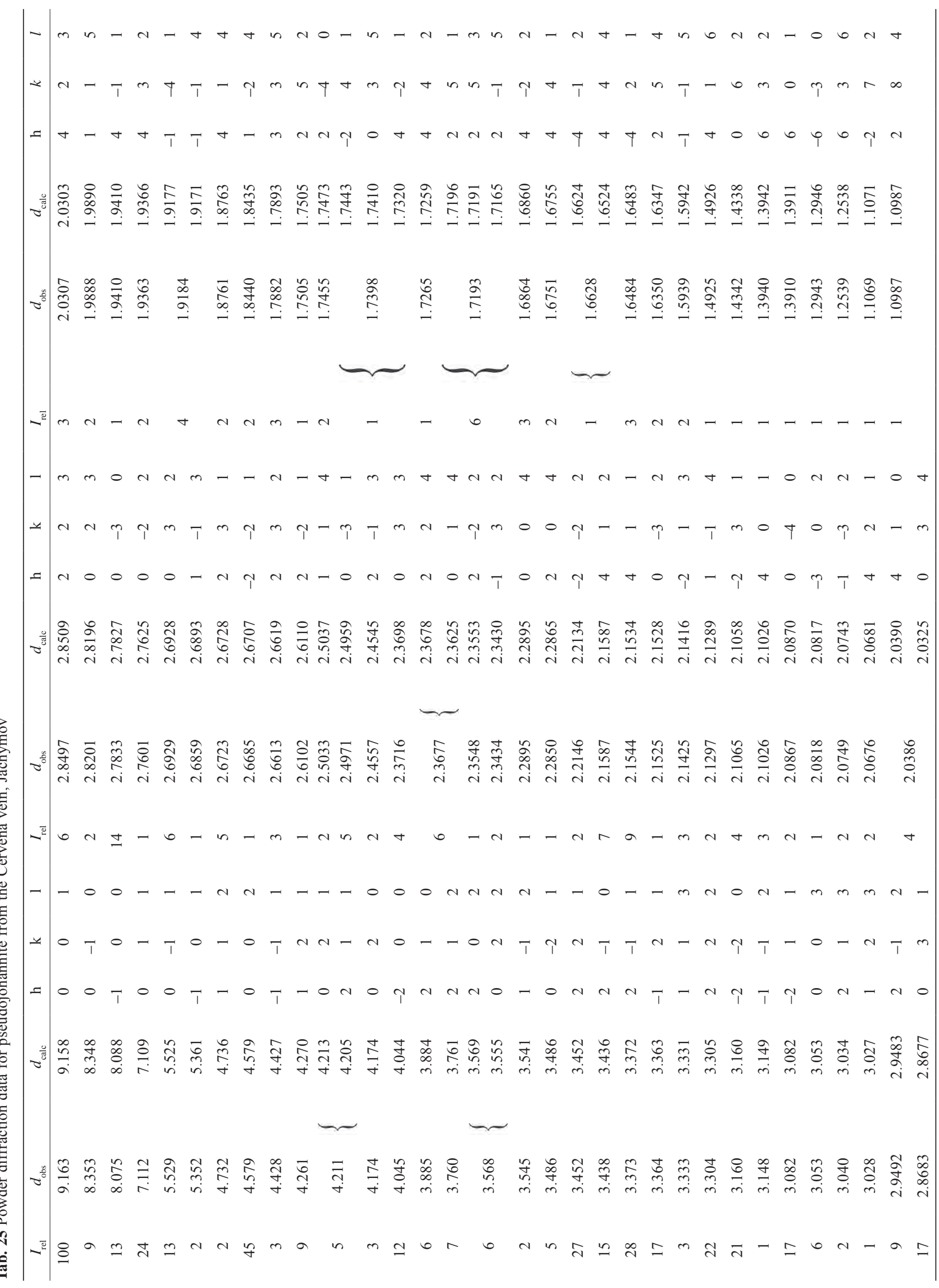


Tab. 26 Refined unit-cell parameters of pseudojohannite (for the triclinic space group $P \overline{1}$ )

\begin{tabular}{lcc}
\hline $\begin{array}{l}\text { Locality } \\
\text { Reference }\end{array}$ & $\begin{array}{c}\text { Červená vein, Jáchymov } \\
\text { single-crystal XRD, this paper }\end{array}$ & $\begin{array}{c}\text { Červená vein, Jáchymov } \\
\text { powder XRD, this paper }\end{array}$ \\
\hline$a[\AA]$ & $8.6918(7)$ & $8.685(2)$ \\
$b[\AA]$ & $8.8812(9)$ & $8.881(2)$ \\
$c[\AA]$ & $10.022(1)$ & $10.028(3)$ \\
$\alpha\left[^{\circ}\right]$ & $72.093(9)$ & $72.09(2)$ \\
$\beta\left[^{\circ}\right]$ & $70.520(8)$ & $70.51(2)$ \\
$\gamma\left[^{\circ}\right]$ & $76.068(8)$ & $76.00(2)$ \\
$V\left[\AA^{3}\right]$ & $685.8(1)$ & $685.5(3)$ \\
\hline Locality $^{\circ}$ & White Canyon, Utah, USA & Jáchymov, holotype specimen \\
Reference & single-crystal, Plášil et al. (2012a) & synchrotron powder data, Plášil et al. $(2012 \mathrm{a})$ \\
\hline$a[\AA]$ & $8.6744(4)$ & $8.68239(3)$ \\
$b[\AA]$ & $8.8692(4)$ & $8.87811(3)$ \\
$c\left[^{\AA}\right]$ & $10.0090(5)$ & $10.02136(4)$ \\
$\alpha\left[^{\circ}\right]$ & $72.105(4)$ & $72.1257(3)$ \\
$\beta\left[^{\circ}\right]$ & $70.544(4)$ & $70.5266(3)$ \\
$\gamma\left[^{\circ}\right]$ & $76.035(4)$ & $76.0207(2)$ \\
$V\left[\AA^{3}\right]$ & $682.61(5)$ & $684.740(5)$ \\
\hline
\end{tabular}

the Variscan orogen, $\sim 190 \mathrm{Ma}$ correlates with Jurassic subsidence and $\sim 120$ Ma may reflect the opening of the North Atlantic Ocean. Late Cretaceous and Tertiary event may be an effect of the Alpine orogeny in the foreland.

\subsection{The abundance of $Y$ and REE}

The relative abundance of supergene minerals containing $\mathrm{Y}$ and REE within the studied association reflects the specific conditions of the vein. It is already known that $\mathrm{Y}$ and $\mathrm{REE}$ are more abundant in the vein

U-deposit Aue-Niederschlema (Saxony), located in the tectonic zone Gera-Jáchymov were $190 \pm 4$ and $120 \pm$ $6 \mathrm{Ma}$ for younger remobilization stages. Further loss of radiogenic $\mathrm{Pb}$ was indicated by ages of $80 \pm 8 \mathrm{Ma}$ and 0-40 Ma. Förster and Haack (1995) concluded that these reflected a crustal reactivation rather than a magmatic activity. The age of $270 \mathrm{Ma}$ corresponds to the collapse of

Tab. 27 Chemical composition of rabejacite (in wt. \%)

\begin{tabular}{lccccc}
\hline & Mean & 1 & 2 & 3 & 4 \\
\hline $\mathrm{BaO}$ & 0.18 & 0.19 & 0.38 & 0.16 & 0.00 \\
$\mathrm{FeO}$ & 0.08 & 0.00 & 0.06 & 0.18 & 0.06 \\
$\mathrm{CaO}$ & 3.82 & 4.01 & 3.51 & 3.75 & 3.99 \\
$\mathrm{ZnO}$ & 0.08 & 0.15 & 0.18 & 0.00 & 0.00 \\
$\mathrm{CuO}$ & 0.50 & 0.92 & 0.94 & 0.00 & 0.13 \\
$\mathrm{P}_{2} \mathrm{O}_{5}$ & 0.09 & 0.17 & 0.00 & 0.00 & 0.16 \\
$\mathrm{SiO}_{2}$ & 0.19 & 0.12 & 0.62 & 0.00 & 0.02 \\
$\mathrm{SO}_{3}$ & 9.49 & 10.01 & 8.89 & 9.08 & 9.97 \\
$\mathrm{UO}_{3}$ & 69.64 & 69.92 & 67.30 & 75.18 & 66.16 \\
$\mathrm{H}_{2} \mathrm{O}_{\text {theor. }}$ & 8.77 & 8.81 & 8.48 & 9.47 & 8.33 \\
\hline $\mathrm{Total}$ & 92.83 & 94.30 & 90.36 & 97.84 & 88.82 \\
\hline $\mathrm{Ba}$ & 0.020 & 0.020 & 0.043 & 0.016 & 0.000 \\
$\mathrm{Fe}$ & 0.017 & 0.000 & 0.014 & 0.038 & 0.015 \\
$\mathrm{Ca}_{\mathrm{Zn}}$ & 1.121 & 1.171 & 1.065 & 1.018 & 1.229 \\
$\mathrm{Cu}$ & 0.017 & 0.030 & 0.037 & 0.000 & 0.000 \\
$\Sigma \mathrm{A}$ site & 0.104 & 0.189 & 0.200 & 0.000 & 0.028 \\
\hline $\mathrm{SiO}$ & 1.279 & 1.410 & 1.359 & 1.062 & 1.272 \\
$\mathrm{SO}_{4}$ & 0.054 & 0.032 & 0.175 & 0.000 & 0.007 \\
$\Sigma T$ site & 1.953 & 2.046 & 1.887 & 1.726 & 2.152 \\
\hline $\mathrm{UO}_{2}{ }^{2+}$ & 4.000 & 4.000 & 4.000 & 4.000 & 4.000 \\
$\mathrm{H}_{2} \mathrm{O}_{\text {theor. }}$ & 8.00 & 8.00 & 8.00 & 8.00 & 8.00 \\
$\mathrm{O}^{\$}$ & 3.19 & 3.24 & 3.12 & 3.34 & 3.05 \\
\hline $\mathrm{C}$ & 2.078 & 2.062 & 1.726 & 2.159 \\
\hline
\end{tabular}

Coefficients of the empirical formula were calculated on the basis of $4 \mathrm{U}$ apfu

$\mathrm{O}^{\$}$ - derived from the charge-balance cluster Rovnost, dominated by the Geister vein. From the outcrops and also underground workings located on this vein are known xenotime-(Y), agardite-(Y) and churchite-(Y) (Ondruš et al. 1997, 2003a; Frost et al. 2010; unpublished data of the current authors) as well as the samples of uranyl-carbonate mineral kamotoite-(Y) (Ondruš et al. 1997). Unfortunately, the latter cannot be localized within a particular vein. The main source of $Y$ and REE in the currently studied weathering association is most likely uraninite. The WDS analyses proved that unaltered uraninite shows elevated contents of $\mathrm{Y}$ and REE and also depletion in these elements with increasing alteration (leached zones) or coffinitization (Fig. 1a, Tab. 1).

Although the chondrite-normalized REE patterns of sejkoraite-(Y) and uraninite (Fig. 2) show coincidently maxima around Dy, they differ. The structure of sejkoraite-(Y) will more strongly prefer the MREE-HREE over LREE (based on their corresponding ionic radii) compared to uraninite.

\subsection{The dominating role of $\mathrm{Cu}^{2+}$}

In all groups of supergene minerals present at Červená vein, the $\mathrm{Cu}^{2+}$ is the dominating constituent. It occurs in cuprosklodowskite (uranyl silicates), pseudojohannite and johannite (uranyl sulfates), in zeunerite and CuUOVO phase (uranyl arsenates/vanadates), and in brochantite/ antlerite (uranium-free sulfates). The high activity of $\mathrm{Cu}$ in the mineral system is also well documented by the fact that $\mathrm{Cu}$ enters minerals, which are nominally $\mathrm{Cu}$-free (marécottite, rabejacite, tyuyamunite, and compreignacite). The character of the primary mineral association is responsible for such abundance of $\mathrm{Cu}^{2+}$, because uraninite is intimately associated with chalcopyrite, tennantite and 
Supergene minerals from the Červená vein, Jáchymov

chalcocite in the carbonate-free quartz gangue. We may divide the alteration into two stages with regard to the release of $\mathrm{Cu}^{2+}$ into the system. First step was weathering of primary $\mathrm{Cu}$ minerals in the vicinity of uraninite, which undergoes oxidation-hydration weathering in the moist air readily. The volume changes in the mineral matrix (cracking etc.) containing hydrating uraninite are considerable (Finch and Ewing 1992) and thus may start up the alteration of other primary minerals. During the first stage were generated concentrated aqueous solutions containing dissolved $\mathrm{UO}_{2}{ }^{2+}, \mathrm{SO}_{4}{ }^{2-}$ and $\mathrm{Cu}^{2+}$ and from these solutions minerals such as pseudojohannite or johannite might have formed. The second stage involved weathering of massive tennantite, chalcopyrite and chalcocite that were not in direct vicinity of uraninite and marcasite and the weathering became slower. Probably during this stage other minerals like brochantite precipitated.

\subsection{Searching for the source of $\mathrm{V}^{5+}$}

There was no apparent primary vanadium-containing mineral found in the studied association. However, in a single polished section dominated by primary minerals - uraninite and sulfides (chalcopyrite, chalcocite) - we noted an interesting mineral phase. Based on EDS it contained major $\mathrm{Fe}, \mathrm{Si}, \mathrm{Al}$ and minor $\mathrm{V}$ and $\mathrm{Cu}$. It formed aggregates in quartz, up to $300 \mu \mathrm{m}$ across, commonly associated with at the contacts more or less coffinitized uraninite. From the BSE and SE images it was obvious that the surface of those parts is uneven and the aggregates are very porous (and probably also chemically inhomogeneous). The EMPA confirmed (Tab. 30) that these aggregates belong to roscoelite, ideally $\mathrm{K}\left(\mathrm{V}^{5+}, \mathrm{Al}, \mathrm{Mg}\right)_{2} \mathrm{AlSi}_{3} \mathrm{O}_{10}(\mathrm{OH})_{2}$, reported from Jáchymov by Šrein and Langrová (1999). This phase may have represented the source for vanadium in the studied mineral system.
Tab. 29 Refined unit-cell parameters for zippeite from Červená vein (for the monoclinic space group $C 2 / m$ )

\begin{tabular}{lcc}
\hline $\begin{array}{l}\text { Locality } \\
\text { Reference }\end{array}$ & $\begin{array}{c}\text { zippeite II, Červená vein } \\
\text { powder XRD, this paper }\end{array}$ & $\begin{array}{c}\text { zippeite I, Červená vein } \\
\text { single-crystal XRD, Plášil et al. (2011b) }\end{array}$ \\
\hline$a[\AA]$ & $8.844(1)$ & $8.7802(6)$ \\
$b[\AA]$ & $14.115(2)$ & $13.9903(12)$ \\
$c[\AA]$ & $8.856(1)$ & $8.8630(6)$ \\
$\beta\left[{ }^{\circ}\right]$ & $104.785(8)$ & $104.524(7)$ \\
$V\left[\AA^{3}\right]$ & $1068.9(3)$ & $1053.92(12)$ \\
\hline
\end{tabular}

\subsection{The bond-valence approach to stereochemistry of uranyl-oxysalts: From the chemical composition to their occurrence}

The stability of hydrated uranyl-oxysalts is driven primarily by the weak bonding interactions between the strongly constituted structural units (behaving as Lewis base) and weakly bonded interlayer complexes (Lewis acid). In order to form stable crystal structures, their structure units and interlayer complexes had to exhibit corresponding values of Lewis basicity/acidity, satisfying the valence matching principle (Brown 2002; Schindler and Hawthorne 2008; Hawthorne 2012). Assuming

Tab. 28 Chemical composition of the $\mathrm{Cu}^{2+}$-rabejacite (in wt. \%)

\begin{tabular}{|c|c|c|c|c|c|c|}
\hline & Mean & 1 & 2 & 3 & 4 & 5 \\
\hline $\mathrm{K}_{2} \mathrm{O}$ & 0.25 & 0.20 & 0.32 & 0.28 & 0.16 & 0.31 \\
\hline $\mathrm{BaO}$ & 0.48 & 0.60 & 0.37 & 0.34 & 0.53 & 0.57 \\
\hline $\mathrm{FeO}$ & 0.17 & 0.23 & 0.13 & 0.23 & 0.13 & 0.13 \\
\hline $\mathrm{CaO}$ & 1.37 & 1.30 & 1.39 & 1.49 & 1.48 & 1.18 \\
\hline $\mathrm{MgO}$ & 0.09 & 0.07 & 0.08 & 0.07 & 0.17 & 0.07 \\
\hline $\mathrm{CuO}$ & 2.78 & 2.50 & 3.64 & 3.14 & 2.84 & 1.80 \\
\hline $\mathrm{Y}_{2} \mathrm{O}_{3}$ & 1.09 & 0.73 & 1.09 & 1.28 & 1.08 & 1.28 \\
\hline $\mathrm{SiO}_{2}$ & 0.43 & 0.40 & 0.27 & 0.27 & 0.47 & 0.77 \\
\hline $\mathrm{V}_{2} \mathrm{O}_{5}$ & 0.65 & 0.67 & 0.26 & 0.38 & 0.94 & 1.00 \\
\hline $\mathrm{SO}_{3}$ & 14.23 & 7.53 & 8.33 & 9.01 & 8.47 & 5.90 \\
\hline $\mathrm{UO}_{3}$ & 72.60 & 71.61 & 74.77 & 74.92 & 77.38 & 64.34 \\
\hline $\mathrm{H}_{2} \mathrm{O}_{\text {theor. }}$ & 9.15 & 9.02 & 9.42 & 9.44 & 9.75 & 8.10 \\
\hline Total & 96.91 & 94.85 & 100.07 & 100.82 & 103.39 & 85.44 \\
\hline $\mathrm{K}$ & 0.085 & 0.067 & 0.103 & 0.089 & 0.050 & 0.118 \\
\hline $\mathrm{Ba}$ & 0.050 & 0.062 & 0.037 & 0.034 & 0.051 & 0.067 \\
\hline $\mathrm{Fe}$ & 0.038 & 0.051 & 0.028 & 0.049 & 0.027 & 0.033 \\
\hline $\mathrm{Ca}$ & 0.384 & 0.370 & 0.379 & 0.406 & 0.391 & 0.373 \\
\hline $\mathrm{Mg}$ & 0.036 & 0.029 & 0.030 & 0.028 & 0.063 & 0.029 \\
\hline $\mathrm{Cu}$ & 0.547 & 0.502 & 0.700 & 0.603 & 0.527 & 0.403 \\
\hline $\mathrm{Y}$ & 0.169 & 0.155 & 0.174 & 0.146 & 0.168 & 0.202 \\
\hline$\Sigma A$ site & 1.309 & 1.236 & 1.451 & 1.255 & 1.277 & 1.225 \\
\hline $\mathrm{SiO}_{4}$ & 0.116 & 0.106 & 0.069 & 0.062 & 0.116 & 0.226 \\
\hline $\mathrm{VO}_{4}$ & 0.115 & 0.118 & 0.043 & 0.064 & 0.152 & 0.196 \\
\hline $\mathrm{SO}_{4}$ & 1.537 & 1.502 & 1.591 & 1.719 & 1.563 & 1.310 \\
\hline$\Sigma T$ site & 1.768 & 1.726 & 1.703 & 1.845 & 1.831 & 1.732 \\
\hline $\mathrm{UO}_{2}{ }^{2+}$ & 4.000 & 4.000 & 4.000 & 4.000 & 4.000 & 4.000 \\
\hline $\mathrm{H}_{2} \mathrm{O}_{\text {theor. }}$ & 8.00 & 8.00 & 8.00 & 8.00 & 8.00 & 8.00 \\
\hline $\mathrm{O}^{\$}$ & 3.41 & 3.39 & 3.69 & 3.45 & 3.31 & 3.21 \\
\hline
\end{tabular}

Coefficients of the empirical formula were calculated on the basis of $4 \mathrm{U}$ apfu $\mathrm{O}^{\$}$ - derived from the charge-balance 
Tab. 30 Chemical composition of roscoelite from Červená vein (in wt. \%)

\begin{tabular}{|c|c|c|c|c|}
\hline & Mean & 1 & 2 & 3 \\
\hline $\mathrm{Na}_{2} \mathrm{O}$ & 0.05 & bdl & bdl & 0.14 \\
\hline $\mathrm{K}_{2} \mathrm{O}$ & 6.51 & 6.61 & 6.43 & 6.45 \\
\hline $\mathrm{CaO}$ & 0.31 & 0.31 & 0.32 & 0.29 \\
\hline $\mathrm{MgO}$ & 1.68 & 1.45 & 1.79 & 1.80 \\
\hline $\mathrm{CuO}$ & 1.24 & 1.38 & 1.15 & 1.18 \\
\hline $\mathrm{Al}_{2} \mathrm{O}_{3}$ & 13.12 & 13.68 & 12.81 & 13.17 \\
\hline $\mathrm{Fe}_{2} \mathrm{O}_{3}$ & 7.80 & 6.97 & 7.57 & 8.87 \\
\hline $\mathrm{SiO}_{2}$ & 45.43 & 44.62 & 45.44 & 43.23 \\
\hline $\mathrm{V}_{2} \mathrm{O}_{5}$ & 13.49 & 13.71 & 13.56 & 13.20 \\
\hline $\mathrm{SO}_{3}$ & 0.11 & 0.21 & 0.10 & bdl \\
\hline $\mathrm{H}_{2} \mathrm{O}_{\text {calc. }}$ & 0.52 & 1.06 & 0.12 & 0.37 \\
\hline Total & 90.23 & 89.68 & 89.29 & 91.74 \\
\hline $\mathrm{Na}$ & 0.007 & - & - & 0.018 \\
\hline K & 0.548 & 0.567 & 0.542 & 0.536 \\
\hline $\mathrm{Ca}$ & 0.022 & 0.022 & 0.022 & 0.020 \\
\hline $\mathrm{Mg}$ & 0.165 & 0.145 & 0.176 & 0.174 \\
\hline $\mathrm{Cu}$ & 0.062 & 0.070 & 0.057 & 0.058 \\
\hline $\mathrm{Al}^{3+}$ & 1.021 & 1.059 & 0.997 & 1.007 \\
\hline $\mathrm{Fe}^{3+}$ & 0.348 & 0.317 & 0.338 & 0.390 \\
\hline $\mathrm{Si}^{4+}$ & 3.000 & 3.000 & 3.000 & 3.000 \\
\hline $\mathrm{V}^{5+}$ & 0.589 & 0.609 & 0.591 & 0.556 \\
\hline $\mathrm{S}^{6+}$ & 0.005 & 0.011 & 0.005 & - \\
\hline $\mathrm{OH}_{\text {calc. }}$ & 0.114 & 0.237 & 0.027 & 0.080 \\
\hline
\end{tabular}

Coefficients of the empirical formula were calculated on the basis of 3 Si apfu

$\mathrm{OH}_{\text {calc. }}$ - derived from the charge-balance

simple crystal-chemical considerations, Schindler and Hawthorne (2008) showed that some properties of the structure units (Lewis basicity, charge-deficiency per anion, respectively) reflect the conditions when such structure unit formed from the solution. These authors developed so-called bond-valence approach to describe the relations between the chemical composition of the

Tab. 31 Overview of the chemical composition of studied weathering association and the CDA values of their structure units

\begin{tabular}{llc}
\hline Mineral & $\mathrm{Composition}$ & $\mathrm{CDA}[\mathrm{vu}](\mathrm{calc})$. \\
\hline Uranopilite & {$\left[\left(\mathrm{UO}_{2}\right)_{6}\left(\mathrm{SO}_{4}\right) \mathrm{O}_{2}(\mathrm{OH})_{6}\left(\mathrm{H}_{2} \mathrm{O}\right)_{6}\right]\left(\mathrm{H}_{2} \mathrm{O}\right)_{8}$} & 0.12 \\
Zippeite & $\mathrm{K}_{2}\left[\left(\mathrm{UO}_{2}\right)_{4} \mathrm{O}_{2}\left(\mathrm{SO}_{4}\right)_{2}(\mathrm{OH})_{2}\right]\left(\mathrm{H}_{2} \mathrm{O}\right)_{4}$ & 0.12 \\
Marécottite & $\mathrm{Mg}_{3}\left[\left(\mathrm{UO}_{2}\right)_{4} \mathrm{O}_{3}(\mathrm{OH})\left(\mathrm{SO}_{4}\right)_{2}\right]_{2}\left(\mathrm{H}_{2} \mathrm{O}\right)_{28}$ & 0.16 \\
Pseudojohannite & $\mathrm{Cu}_{3}(\mathrm{OH})_{2}\left[\left(\mathrm{UO}_{2}\right)_{4} \mathrm{O}_{4}\left(\mathrm{SO}_{4}\right)_{2}\right]\left(\mathrm{H}_{2} \mathrm{O}\right)_{12}$ & 0.20 \\
Sejkoraite- $(\mathrm{Y})$ & $\mathrm{Y}_{3}(\mathrm{OH})_{2}\left[\left(\mathrm{UO}_{2}\right)_{8} \mathrm{O}_{7} \mathrm{OH}\left(\mathrm{SO}_{4}\right)_{4}\right]\left(\mathrm{H}_{2} \mathrm{O}\right)_{24}$ & 0.23 \\
Rabejacite* & $\mathrm{Ca}_{2}\left[\left(\mathrm{UO}_{2}\right)_{4} \mathrm{O}_{4}\left(\mathrm{SO}_{4}\right)_{2}\right]\left(\mathrm{H}_{2} \mathrm{O}\right)_{9}$ & 0.20 \\
Johannite & $\mathrm{Cu}\left[\left(\mathrm{UO}_{2}\right)_{2}\left(\mathrm{SO}_{4}\right)_{2}(\mathrm{OH})_{2}\right]\left(\mathrm{H}_{2} \mathrm{O}\right)_{8}$ & 0.17 \\
Soddyite & {$\left[\left(\mathrm{UO}_{2}\right)_{2}\left(\mathrm{SiO}_{4}\right)\left(\mathrm{H}_{2} \mathrm{O}\right)_{2}\right]$} & 0.08 \\
Cuprosklodowskite & $\mathrm{Cu}\left[\left(\mathrm{UO}_{2}\right) \mathrm{SiO}_{3} \mathrm{OH}_{2}\left(\mathrm{H}_{2} \mathrm{O}\right)_{6}\right.$ & 0.20 \\
Schoepite & {$\left[\left(\mathrm{UO}_{2}\right)_{8} \mathrm{O}_{2}(\mathrm{OH}]_{12}\right]\left(\mathrm{H}_{2} \mathrm{O}\right)_{12}$} & 0.08 \\
Compreignacite & $\mathrm{K}_{2}\left[\mathrm{UO}_{2}\right)_{3} \mathrm{O}_{2}\left(\mathrm{OH}_{3}\right)_{2}\left(\mathrm{H}_{2} \mathrm{O}\right)_{7}$ & 0.15 \\
Tyuyamunite & $\mathrm{Ca}\left[\left(\mathrm{UO}_{2}\right)_{2}(\mathrm{VO})_{2}\right]\left(\mathrm{H}_{2} \mathrm{O}\right)_{\mathrm{n}}$ & 0.17 \\
Zeunerite & $\mathrm{Cu}\left[\left(\mathrm{UO}_{2}\right)_{2}(\mathrm{AsO})_{2}\right]\left(\mathrm{H}_{2} \mathrm{O}\right)_{6}$ & 0.17 \\
Antlerite & $\mathrm{Cu}\left(\mathrm{SO}_{4}\right)(\mathrm{OH})_{4}$ & 0.10 \\
Brochantite & $\mathrm{Cu}\left(\mathrm{SO}_{4}\right)(\mathrm{OH})_{6}$ & 0.12 \\
\hline
\end{tabular}

$[v u]$ - valence units; * preliminary estimation of the current authors e.g., uranyl-oxysalts (Schindler et al. 2000; Schindler and Hawthorne 2001a-c, 2004, 2008), and their stability. In the following paragraph we would focus on currently studied association and point out some conclusions based on the above-mentioned approach. We use the terminology that will not be reviewed here, as it is beyond the scope of the current paper. For explanations of the terms used, we advise the reader to check the papers by Schindler and Hawthorne (2001a, 2008), Hawthorne and Schindler (2008), Brown (2009) and Hawthorne (2012).

Schindler et al. (2000) introduced a variable called "average basicity of the structural unit", re-named later to the "charge-deficiency per anion" (CDA). It is defined as the average bond-valence per $\mathrm{O}$ atom contributed by the interstitial species and adjacent structural units. It is an extremely important variable as it correlates strongly with the average O-coordination number of the structural unit, and hence plays a crucial role in the predictive power of the bond-valence approach. The charge-deficiency per anion values represent the average bond-valence per $\mathrm{O}$ atom required by the structural unit to satisfy the principle of correspondence of Lewis acidity-basicity, the mean-field equivalent of the "valence-matching principle" of the bond-valence theory (Brown 2009; Hawthorne 2012). It was demonstrated in the papers mentioned above that the $\mathrm{CDA}$ value depends on the $\mathrm{pH}$ of the solution, from which such a structure (or structural units or fragments) forms. Conversely, when considering the formation of some mineral association and its evolution, it is very useful to look at its composition from the point of view of the bondvalence approach. Similar method has been recently applied by Plášil et al. (2014) to evaluate $\mathrm{SO}_{4}$-rich alteration association from the Blue Lizard mine in Utah (U.S.A.).

The overview of the CDA values, characteristic of the structure units of studied supergene association, is given in Tab. 31. The minerals may be grouped into clusters, defined by the similar values of CDA, matching well the mineral associations observed. As noticed above, the CDA value generally increases with the increasing $\mathrm{pH}$ of the system. The absence of carbonates leads to the formation of locally very acid solutions rich in $\mathrm{SO}_{4}^{2-}$ (through the decomposition of pyrite and chalcopyrite) and $\mathrm{AsO}_{4}^{3-}$ (from tennantite). They contain also dissolved cations from the decomposed minerals, namely $\mathrm{Cu}, \mathrm{Fe}$ or $\mathrm{U}^{6+}$. The evolution of the solutions and subsequent processes involving formation 
of supergene minerals are probably variable. However, we may assume that the successive evolution of the $\mathrm{pH}$ depends on the incoming supply from the source and also the kinetics of the reactions in the solution involving the mineral formation.

By the lowest value of CDA are characterized soddyite, $\left[\left(\mathrm{UO}_{2}\right)_{2}\left(\mathrm{SiO}_{4}\right)\left(\mathrm{H}_{2} \mathrm{O}\right)_{2}\right]$, found also within the studied association, and schoepite, $\left[\left(\mathrm{UO}_{2}\right)_{8} \mathrm{O}_{2}(\mathrm{OH}]_{12}\right]$ $\left(\mathrm{H}_{2} \mathrm{O}\right)_{12}$. Based on Schindler and Hawthorne (2001c), we know that such minerals usually form from the solution of the lowest $\mathrm{pH}$ within the particular system and when the activity of all cations in the solution is low (!). Such conditions are characteristic, for instance, of the very initial stages of uraninite alteration. Indeed, schoepite is usually described as the first phase to form from oxidation-hydration weathering (Schindler and Hawthorne 2004). Soddyite was found only in one specimen, isolated from other phases. Schoepite was not detected within the association; however, closely related minerals, such as the cation-deficient compreignacite and compreignacite were identified. Those minerals are characterized by high CDA values. Uranopilite (CDA $\sim 0.12 v u$ ) usually occurs somewhat isolated or with other sulfates that have higher CDA (like the association of rabejacite $+(\mathrm{Ca} / \mathrm{Cu}$ )-rabejacite + cuprosklodowskite). Similarly, zippeite (CDA $\sim 0.12$ $v u$ ) is more or less isolated from other uranyl-sulfates in the studied specimens. The very typical assemblage is represented by pseudojohannite, compreignacite (also containing $\mathrm{Cu}^{2+}$ ) and cuprosklodowskite. Another copper uranyl-sulfate, johannite, occurs somewhat isolated from the above-mentioned phases (even if on the same sample), which is supported by the lower value of CDA, suggesting that the mineral formed from more acid solutions. Sejkoraite-(Y) occurs usually in association with rabejacite or $\mathrm{Cu} / \mathrm{Y}$-rabejacite (CDA $\sim 0.20-0.23$ ). The Cu-marécottite was found together with cuprosklodowskite (CDA 0.16 and 0.20 $v u$ ); however, they never form intergrowths and occur isolated in the given specimen. Zeunerite, as well as tyuyamunite-like phases were found isolated from other minerals. The different conditions of origin may also be supported by the value of CDA $(\sim 0.17 v u)$ distinct from other phases. Brochantite (CDA $\sim 0.12 v u$ ) is present in most samples, while antlerite (CDA $\sim 0.10$ $v u$ ) was identified only in a few. Brochantite is a very common mineral. It occurs usually somewhat isolated from the other phases; however, remarkable minerals, found in a closer association, are compreignacite, $\mathrm{Cu}^{2+}$ bearing compreignacite $(0.15 \mathrm{vu})$ or cuprosklodowskite $(0.20 \mathrm{vu})$.

While discussing the mineral stabilities, we have to consider an increasing number of thermodynamic/ solubility data for uranyl minerals and especially for uranyl-oxide hydroxy-hydrates (i.e., Jang et al. 2006; Kubatko et al. 2006; Gorman-Lewis et al. 2007; Gorman-Lewis et al. 2008a, b; Shvareva et al. 2012). Most recent review of the thermodynamic data for metaschoepite (Kubatko et al. 2006) showed that metaschoepite, and also schoepite as precursor, are thermodynamically unstable at any conditions. If there is a significant amount of $\mathrm{Si}^{4+}$ dissolved in the solution, uranyl silicates form and replace metaschoepite/schoepite (Shvareva et al. 2012). The products of similar processes were documented from nature (e.g., Thoreau and Vaes 1932). Soddyite might form under low $\mathrm{pH}$ conditions, high $\mathrm{Si}^{4+}$ activity and low activity of low-valence cations in the solution (Shvareva et al. 2012). When activity of mono- or divalent cations increases (along with low activity of $\mathrm{Si}^{4+}, \mathrm{P}^{5+}$ and $\mathrm{As}^{5+}$ ), formation of uranyl-oxide hydroxy-hydrate is favored (Shvareva et al. 2012). In the paragenetic sequence, uranyl-oxide hydroxy-hydrate minerals containing monovalent cations will occur under lower $\mathrm{pH}$ and lower activity of $\mathrm{M}^{2+}$ (Schindler and Hawthorne 2004). The CDA value of the structural units in uranyl-oxide hydroxyhydrate minerals varies over a relatively narrow range $(0.08-0.29 v u)$, which reflects the small range of $\mathrm{pH}$ (5 to 8 ) over which almost all of these minerals have their maximum stability (Schindler and Hawthorne 2004) as supported by the dissolution experiments (Gorman-Lewis et al. 2008a, b). With respect to our observations, we may conclude that due to the high activity of $\mathrm{Cu}^{2+}, \mathrm{S}^{6+}$ and $\mathrm{Si}^{4+}$ in the solution, the early alteration phases are of limited importance. If present, they are represented by compreignacite-like phases or very rarely occurring uranyl-silicate soddyite. The high activity of $\mathrm{Cu}^{2+}$ and $\mathrm{Si}^{4+}$ favors the formation of cuprosklodowskite instead of typical uranophane abundant when $\mathrm{Ca}^{2+}$ is available. As the early alteration products we may present uranyl-sulfate minerals uranopilite (high molar proportion of $\mathrm{UO}_{3}$ and $\mathrm{H}_{2} \mathrm{O}$ in the structure formula) and also zippeite. As stated above, the existence of new $\mathrm{Cu}^{2+}$-containing uranyl-oxide hydroxy-hydrate mineral is highly possible. Within the family of the uranyl-oxide hydroxy-hydrate minerals exists vandenbrandeite, $\mathrm{Cu}\left(\mathrm{UO}_{2}\right)(\mathrm{OH})_{4}$ (Schoep 1932), containing electro-neutral sheets of the vandenbrandeite anion-topology (Rosenzweig and Ryan 1977; Burns 2005). However, the composition of this phase does not fit the studied association. The CDA value of $0.47 v u$ suggests that the mineral should be stable under much more alkaline conditions, similar as e.g. other exotic uranyl-oxide hydroxy-hydrate mineral uranosphaerite, $\mathrm{Bi}\left(\mathrm{UO}_{2}\right) \mathrm{O}_{2} \mathrm{OH}$ (Hughes et al. 2003). It seems that in the paragenetic sequence this gap can be replaced by $\mathrm{Cu}$-dominant compreignacite, which may represent a new mineral species. 


\section{Conclusions}

The studied mineral association represents a typical example of U-rich acid-mine drainage mineral assemblage of recent origin. The very typical features of the supergene geochemistry originated from the chemical composition of both the primary ores and the surrounding rocks: the high activity of $\mathrm{Cu}^{2+}$ (from dissolved chalcopyrite), the abundance of $\mathrm{Y}$ and REE (from uraninite) and the presence of $\mathrm{V}^{5+}$ (from a dissolved $\mathrm{Fe}-\mathrm{V}-$ $\mathrm{Si}-\mathrm{O}$ phase, probably similar to montroseite). The several alteration associations were identified within the studied assemblage. They do not differ in terms of their temporal evolution (as it is well known from the group of $\mathrm{Pb}^{2+}$-containing uranyl-oxide hydroxy-hydrate minerals), but they are distinct in terms of the $\mathrm{pH}$ under which they formed and also the activity of cations in the solution. Both features vary on the microscale, as it is characteristic of such a mineralization. There are minerals stable at low $\mathrm{pH}$ and absence of any metal in the solution, e.g., uranopilite, and those stable at higher $\mathrm{pH}$ and higher activity of metal cations, e.g., brochantite. The studied minerals do not represent an in-situ stable mineral association of the supergene zone, but rather that of the initial weathering-stages of primary uranium minerals forming under the acid conditions.

Acknowledgements. We would like to acknowledge the mineral collectors Radim Pavlíček, Bohuslav Bureš and Jan Hykš for having provided the specimens used in the study and for their support of this research. We thank Karla Fejfarová, Michal Dušek and Jan Rohlíček (Institute of Physics, ASCR, v.v.i.) and Viktor Goliáš (Faculty of Science, Charles University in Prague) for their kind help with the collection of the diffraction data. Jana Ederová (Institute of Chemical Technology, Prague), Martin Mazuch (Charles University, Prague) and Boris Ekrt (National Museum, Prague) are acknowledged for help during the experiments. The manuscript benefited from the constructive reviews by Evgeny Galuskin and Sergey Krivovichev. The editorial care by handling editor František Laufek and editor-in-chief Vojtěch Janoušek is also highly appreciated. The research was financially supported by the Premium Academiae grant of the ASČR and also by the post-doctoral grant of the GAČR no. 13-31276P to JP. Further financial support was from the Ministry of Culture of the Czech Republic (project DKRVO 2013/01 and DKRVO 2014/02, National Museum 00023272) to JS.

Electronic supplementary material. Supplementary crystallographic data for this paper are available on-line at the Journal web site (http://dx.doi.org/10.3190/jgeosci.171).

\section{References}

Agilent Technologies (2012) CrysAlis CCD and CrysAlis RED. Oxford Diffraction Ltd, Yarnton, Oxfordshire, UK

Basciano LC, Peterson RC (2007) Jarosite-hydronium jarosite solid-solution series with full iron site occupancy: mineralogy and crystal chemistry. Amer Miner 92: 1464-1473

Basciano LC, Peterson RC (2008) Crystal chemistry of the natrojarosite-jarosite and natrojarosite-hydronium jarosite solid solution series: a synthetic study with full iron site occupancy. Amer Miner 93: 853-862

Basciano LC, Peterson RC (2010) A crystallographic study of the incomplete solid-solution between plumbojarosite and jarosite. Canad Mineral 48: 651-659

BÉRAR J-F, LELLAN P (1991) E.s.d.'s and estimated probable errors obtained in Rietveld refinements with local correlations. J Appl Crystallogr 24: 1-5

BROwN ID (1981) The bond-valence method: an empirical approach to chemical structure and bonding. In: O'KEEFFE M, Navrotsky A (eds) Structure and Bonding in Crystals. Academic Press, New York, pp 1-30

Brown ID (2002) The Chemical Bond in Inorganic Chemistry. The Bond Valence Model. Oxford University Press, Oxford, pp 1-288

Brown ID (2009) Recent developments in the methods of the bond valence model. Chem Rev 109: 6858-6919

Brugger J, Meisser N, Burns PC (2003) Contribution to the mineralogy of acid drainage of uranium minerals: marecottite and the zippeite-group. Amer Miner 88: 676-685

Brugger J, Wallwork KS, Meisser N, Pring A, Ondruš P, ČEJKA J (2006) Pseudojohannite from Jáchymov, Musunoï and La Creusaz: a new member of the zippeite group. Amer Miner 91: 929-936

Burns PC (1998) The structure of compreignacite, $\left.\mathrm{K}_{2}\left(\mathrm{UO}_{2}\right)_{3} \mathrm{O}_{2}(\mathrm{OH})_{3}\right]_{2}\left(\mathrm{H}_{2} \mathrm{O}\right)_{7}$. Canad Mineral 36: $1061-$ 1067

Burns PC (2001) A new uranyl sulfate chain in the structure of uranopilite. Canad Mineral 39: 1139-1146

BuRns PC (2005) $\mathrm{U}^{6+}$ minerals and inorganic compounds: insights into an expanded structural hierarchy of crystal structures. Canad Mineral 43: 1839-1894

Clark RC, ReID JS (1995) The analytical calculation of absorption in multifaceted crystals. Acta Cryst A51: 887-897

Chen L, Li J-W, Rye RO, Benzel WM, Lowers HA, He M-Z (2013) Mineralogical, chemical, and crystallographic properties of supergene jarosite-group minerals from the Xitieshan $\mathrm{Pb}-\mathrm{Zn}$ sulfide deposit, northern Tibetan Plateau, China. Mineral Petrol 107: 487-499

Deditius AP, Utsunomyia S, Ewing RC (2007a) Alteration of $\mathrm{UO}_{2+\mathrm{x}}$ under oxidizing conditions, Marshall Pass, Colorado, USA. J All Comp 444-445: 584-589 
Deditius AP, Utsunomyia S, Ewing RC (2007b) Fate of trace elements during alteration of uraninite in a hydrothermal vein-type U-deposit from Marshall Pass, Colorado, USA. Geochim Cosmochim Acta 71: 4954-4972

Demartin F, Gramaccioli C M, Pilati T (1992) The importance of accurate crystal structure determination of uranium minerals. II. Soddyite $\left(\mathrm{UO}_{2}\right)_{2}\left(\mathrm{SiO}_{4}\right)_{2} \mathrm{H}_{2} \mathrm{O}$. Acta Cryst C48: 1-4

Fernandes HM, Veiga lHS, Franklin MR, Prado VCS, TADDEI JF (1995) Environmental impact assessment of uranium mining and milling facilities; a study case at the Pocos de Caldas uranium mining and milling site, Brazil. In: Allan RJ, Salomons W (eds) Heavy Metal Aspects of Mining Pollution and Its Remediation. Elsevier, Amsterdam, pp 161-173

Finch RJ, EwING RC (1992) The corrosion of uraninite under oxidizing conditions. J Nucl Mater 190: 133-156

Finch RJ, Murakami T (1999) Systematics and paragenesis of uranium minerals. In: BuRNs PC, EwING RC (eds) Uranium: Mineralogy, Geochemistry and the Environment. Mineralogical Society of America and Geochemical Society Reviews in Mineralogy and Geochemistry 38: pp 91-179

Förster, B, HaAck, U (1995) U/Pb Datierungen von Pechblenden und die hydrothermale Entwicklung der U-lagersttäte Aue-Niederschlema (Erzgebirge). Z Geol Wiss 23: 581-588

Frost RL, Sejkora J, Keeffe eC, Plášil J, Čejka J, BAHFENNE S (2010) Raman spectroscopic study of the phosphate mineral churchite-(Y), $\mathrm{YPO}_{4} \cdot 2 \mathrm{H}_{2} \mathrm{O}$. J Raman Spectrosc 41: 202-206

Galuskin EV, Armbruster T, Galuskina IO, Lazic B, Winiarski A, Gazeev VM, Dzierźanowski P, Zadov AE (2011) Vorlanite $\left(\mathrm{CaU}^{6+}\right) \mathrm{O}_{4}$ - a new mineral from the Upper Chegem caldera, Kabardino-Balkaria, northern Caucasus, Russia. Amer Miner 96: 188-196

Galuskina IO, Galuskin EV, Armbruster T, Lazic B, Kusz J, Dzierżanowski P, Gazeev VM, Pertsev NN, Prusik $\mathrm{K}$, Zadov AE, Winiarski A, Wrzalik R, Gurbanov AG (2010) Elbrusite-(Zr) - a new uranian garnet from the Upper Chegem caldera, Kabardino-Balkaria, northern Caucasus, Russia. Amer Miner 95: 1172-1181

Gorman-Lewis D, Mazeina L, Fein JB, Szymanowski JES, Burns PC, Navrotsky A (2007) Thermodynamic properties of soddyite from solubility and calorimetry measurements. J Chem Thermodyn 39: 568-575

Gorman-Lewis D, Burns PC, Fein JB (2008a) Review of uranyl mineral solubility measurements. J Chem Thermodyn 40: 335-352

Gorman-Lewis D, Fein JB, Burns PC, Szymanowski JeS, Converse J (2008b) Solubility measurements of the uranyl oxide hydrate phases metaschoepite, compreignacite, Na-compreignacite, becquerelite, and clarkeite. J Chem Thermodyn 40: 980-990
HAwTHORNE FC (2012) A bond-topological approach to theoretical mineralogy: crystal structure, chemical composition and chemical reactions. Phys Chem Miner 39: $841-874$

Hawthorne FC, Schindler M (2008) Understanding the weakly bonded constituents in oxysalt minerals. Z Kristall 223: 41-68

Hughes KA, Burns PC, Kolitsch U (2003) The crystal structure and crystal chemistry of uranosphaerite, $\mathrm{Bi}\left(\mathrm{UO}_{2}\right) \mathrm{O}_{2} \mathrm{OH}$. Canad Mineral 41: 677-685

JANECZEK J, EWING RC (1992) Structural formula of uraninite. J Nucl Mater 190: 128-132

Jang JH, Dempsey BA, Burgos WD (2006) Solubility of schoepite: comparison and selection of complexation constants for U(VI). Water Resour 40: 2738-274

Kraus W, Nolze G (1996) POWDER CELL - a program for the representation and manipulation of crystal structures and calculation of the resulting X-ray powder patterns. J Appl Cryst 29: 301-303

Krivovichev SV, Pléšil J (2013) Mineralogy and crystallography of uranium. In: Burns PC, Sigmon GE (eds) Uranium: From Cradle to Grave. Mineralogical Association of Canada Short Courses 43: pp 15-119

Kubatko KAH, Helean K, Burns PC, Navrotsky A (2006) Thermodynamics of uranyl minerals: enthalpies of formation of uranyl oxide hydrates. Amer Miner 91: 658-666

Laugier J, Bochu B (2004) CELREF: Unit Cell Refinement Program from Powder Diffraction Diagram. Laboratoires des Matériaux et du Génie Physique, Ecole Nationale Supérieure de Physique de Grenoble (INPG), Grenoble, France. Accessed on May 30, 2014, at http://pcb4122. univ-lemans.fr/du-sdpd/nexus/ccp14/web/tutorial/lmgp/ index.htm

Legierski J (1973) Model ages and isotopic composition of ore leads of the Bohemian Massif. Čas Mineral Geol 18: $1-23$

Locock AJ, Burns PC (2003) Crystal structures and synthesis of the copper-dominant members of the autunite and meta-autunite groups: torbernite, zeunerite, metatorbernite and metazeunerite. Canad Mineral 41: 489-502

Majzlan J, Stevens R, Boerio-Goates J, Woodfield BF, Navrotsky A, Burns PC, Crawford MK, Amos TG (2004) Thermodynamic properties, low-temperature heat-capacity anomalies, and single-crystal $\mathrm{X}$-ray refinement of hydronium jarosite, $\left(\mathrm{H}_{3} \mathrm{O}\right) \mathrm{Fe}_{3}\left(\mathrm{SO}_{4}\right)_{2}(\mathrm{OH})_{6}$. Phys Chem Miner 31: 518-531

McDonough WF, Sun SS (1995) The composition of the Earth. Chem Geol 120: 223-253

Meisser N (2012) La minéralogie de l'uranium dans le massif des Aiguilles Rouges. Matér Géol Suisse, Sér géotech 96: 1-183

Meisser N, Brugger J, Lahaye Y (2002) Mineralogy and acid-mine drainage of La Creusaz uranium prospect, Switzerland. In: KŘíbek B, Zeman J (eds) Uranium 
Deposits: From Their Genesis to Their Environmental Aspects. Czech Geological Survey, Prague, pp 147-150 Mereiter K (1982) Zur Kentniss des Minerals Johannit. Mitt Abt Miner Landesmuseum Joanneum 50: 215-220

Merlino S, Perchiazzi N, Franco D (2003) Brochantite, $\mathrm{Cu}_{4} \mathrm{SO}_{4}(\mathrm{OH})_{6}$ : OD character, polytypism and crystal structure. Eur J Mineral 15: 267-275

Mills SJ, Kampf A, Pasero M, Merlino S (2010) Discreditation of "orthobrochantite" (IMA 78-64) as the MDO, polytype of brochantite. Eur J Mineral 22: 453-457

Montel JM, Foret S, Veschambre M, Nicollet C, Provost A (1996) Electron microprobe dating of monazite. Chem Geol 131: 37-53

Ondruš P, Veselovský F, Hloušek J, Skála R, VavŘín I, FrÝdA J, ČEJKA J, GabAšová A (1997) Secondary minerals of the Jáchymov (Joachimsthal) ore district. J Czech Geol Soc 42: 3-76

Ondruš P, Veselovský F, Gabašová A, Hloušek J, Šrein V (2003a) Geology and hydrothermal vein system of the Jáchymov (Joachimsthal) ore district. J Czech Geol Soc 48: 3-18

Ondruš P, Veselovský F, Gabašová A, Hloušek J, Šrein V, Vavǩín I, Skála R, Sejkora J, Drábek M (2003b) Primary minerals of the Jáchymov ore district. J Czech Geol Soc 48: 19-147

Ondruš P, Veselovský F, Gabašová A, Hloušek J, Šrein V (2003c) Supplement to secondary and rock-forming minerals of the Jáchymov ore district. J Czech Geol Soc 48: $149-155$

Ondruš P, Veselovský F, Gabašová A, Drábek M, Dobeš P, Malý K, Hloušek J, SejKora J (2003d) Ore-forming processes and mineral parageneses of the Jáchymov ore district. J Czech Geol Soc 48: 157-192

Palatinus L, Chapuis G (2007) Superflip - a computer program for the solution of crystal structures by charge flipping in arbitrary dimensions. J Appl Cryst 40: $451-456$

Pearcy EC, Prikryl JD, Murphy WM, Leslie BW (1994) Alteration of uraninite from the Nopal I deposit, Peña Blanca District, Chihuahua, Mexico, compared to degradation of spent nuclear fuel in the proposed U.S. high-level nuclear waste repository at Yucca Mountain, Nevada. Appl Geochem 9: 713-732

PetŘí̌̌ek V, Dušek M, Palatinus L (2006) Jana2006. The crystallographic computing system. Institute of Physics, Praha. Accessed on January 22, 2014, at http://jana.fzu.cz

Petříček V, Dušek M, Palatinus L (2014) Crystallographic computing system Jana2006: general features. Z Kristall 229: $345-352$

Piret P, Declerce J-P, Wauters-Stoop D (1980) Structure cristalline de la sengiérite. Bull Minéral 103: 176-178 (in French with English abstract)

Plášil J, Sejkora J, ŠKácha P, Goliáš V, Hušák M (2005) Uranophane, uranopilite and compreignacite from the
Jánská vein, Březové Hory, Př́ibram. Bull mineral-petrolog Odd Nár Muz (Praha) 13: 192-196 (in Czech)

Pléšill J, Sejkora J, Ondruš P, Veselovský F, Beran P, Goliáš V (2006) Supergene minerals in the Horní Slavkov uranium ore district, Czech Republic. J Czech Geol Soc 51: 149-158

Plášil J, Sejkora J, Goliáš V (2008) Cuprosklodowskite from the uranium deposit Zálesí near Javorník in the Rychlebské hory Mountains (Czech Republic). Bull mineral-petrolog Odd Nár Muz (Praha) 16: 205-207 (in Czech with English abstract)

Plášil J, Sejkora J, ČejKa J, Škoda R, Goliáš V (2009) Supergene mineralization of the Medvědín uranium deposit, Krkonoše Mountains, Czech Republic. J Geosci 54: $15-56$

Plášil J, SejKora J, ČejKa J, Novák M, Viñals J, Ondruš P, VeselovskÝ F, ŠK KÁCha P, JeHLičKa J, Goliáš V, HLOUŠEK $\mathrm{J}$ (2010) Metarauchite, $\mathrm{Ni}\left(\mathrm{UO}_{2}\right)_{2}\left(\mathrm{AsO}_{4}\right)_{2} \cdot 8 \mathrm{H}_{2} \mathrm{O}$, from Jáchymov, Czech Republic, and Schneeberg, Germany: a new member of the autunite group. Canad Mineral 48: $335-350$

Plášil J, Dušek M, NovÁk M, ČEJKa J, CísaŘová I, ŠKoda R (2011a) Sejkoraite-(Y), a new member of the zippeite group containing trivalent cations from Jáchymov (St. Joachimsthal), Czech Republic: description and crystal structure refinement. Amer Miner 96: 983-991

Plášil J, Mills SJ, Fejfarová K, Dušek M, Novák M, ŠKoda R, ČEJKa J, SEJKora J (2011b) The crystal structure of natural zippeite, $\mathrm{K}_{1.85} \mathrm{H}^{+}{ }_{0.15}\left[\left(\mathrm{UO}_{2}\right)_{4} \mathrm{O}_{2}\left(\mathrm{SO}_{4}\right)_{2}(\mathrm{OH})_{2}\right]\left(\mathrm{H}_{2} \mathrm{O}\right)_{4}$, from Jáchymov, Czech Republic. Canad Mineral 49: 1089-1103

Plášil J, Fejfarová K, Wallwork KS, Dušek M, ŠKoda R, Sejkora J, Čejka J, Veselovský F, Hloušek J, Meisser N, BRUgGer J (2012a) Crystal structure of pseudojohannite, with a revised formula, $\mathrm{Cu}_{3}(\mathrm{OH})_{2}\left[\left(\mathrm{UO}_{2}\right)_{4} \mathrm{O}_{4}\left(\mathrm{SO}_{4}\right)_{2}\right]$ $\left(\mathrm{H}_{2} \mathrm{O}\right)_{12}$. Amer Miner 97: 1796-1803

Plášsil J, Hloušek J, Veselovský F, Fejfarová K, Dušek M, ŠKoda R, Novák M, ČeJKa J, SeJKora J, Ondruš P (2012b) Adolfpateraite, $\mathrm{K}\left(\mathrm{UO}_{2}\right)\left(\mathrm{SO}_{4}\right)(\mathrm{OH})\left(\mathrm{H}_{2} \mathrm{O}\right)$, a new uranyl sulphate mineral from Jáchymov, Czech Republic. Amer Miner 97: 447-454

Plášill J, Fejfarová K, Hloušek J, Škoda R, Novák M, SejkORA J, ČEJKa J, DuŠEK M, Veselovský F, Ondruš P, MaJZLAN J, MRÁzeK Z (2013a) Štěpite, $\mathrm{U}\left(\mathrm{AsO}_{3} \mathrm{OH}\right)_{2} \cdot 4 \mathrm{H}_{2} \mathrm{O}$, from Jáchymov, Czech Republic: the first natural arsenate of tetravalent uranium. Mineral Mag 77: 137-152

Plášil J, Fejfarová K, ŠKoda R, Dušek M, Marty J, Č́ EJKa J (2013b) The crystal structure of magnesiozippeite, $\mathrm{Mg}\left[\left(\mathrm{UO}_{2}\right)_{2} \mathrm{O}_{2}\left(\mathrm{SO}_{4}\right)\right]\left(\mathrm{H}_{2} \mathrm{O}\right)_{3.5}$, from East Saddle Mine, San Juan County, Utah (U.S.A.). Mineral Petrol 107: 211-219

PLÁšil J (2014) Oxidation-hydration weathering of uraninite: the current state-of-knowledge. J Geosci 59: 99-114

Plášil J, KampF AR, Kasatkin AV, Marty J (2014) Bluelizardite, $\mathrm{Na}_{7}\left(\mathrm{UO}_{2}\right)\left(\mathrm{SO}_{4}\right)_{4} \mathrm{Cl}\left(\mathrm{H}_{2} \mathrm{O}\right)_{2}$, a new uranyl sulfate 
mineral from the Blue Lizard mine, San Juan County, Utah, USA. J Geosci 59: 145-158

Pouchou JL, PICHOIR F (1985) "PAP" $(\varphi \rho Z)$ procedure for improved quantitative microanalysis. In: ARMSTRONG JT (ed) Microbeam Analysis. San Francisco Press, San Francisco, pp 104-106

RosenzweIGA, Ryan RR (1975) Refinement of the crystal structure of cuprosklodowskite, $\mathrm{Cu}\left(\mathrm{UO}_{2}\right)_{2}\left(\mathrm{SiO}_{3} \mathrm{OH}\right)_{2}\left(\mathrm{H}_{2} \mathrm{O}\right)_{6}$. Amer Miner 60: 448-453

Rosenzweig A, Ryan RR (1977) Vandenbrandeit, $\mathrm{CuUO}_{2}(\mathrm{OH})_{4}$. Cryst Struct Comm 6: 53-56

Schindler M, Hawthorne FC (2001a) A bond-valence approach to the structure, chemistry and paragenesis of hydroxy-hydrated oxysalt minerals. I. Theory. Canad Mineral 39: 1225-1242

Schindler M, Hawthorne FC (2001b) A bond-valence approach to the structure, chemistry and paragenesis of hydroxy-hydrated oxysalt minerals. II. Crystal structure and chemical composition of borate minerals. Canad Mineral 39: 1243-1256

Schindler M, Hawthorne FC (2001c) A bond-valence approach to the structure, chemistry and paragenesis of hydroxy-hydrated oxysalt minerals. III. Paragenesis of borate minerals. Canad Mineral 39: 1257-1274

Schindler M, Hawthorne FC (2004) A bond-valence approach to the uranyl-oxide hydroxy-hydrate minerals: chemical composition and occurrence. Canad Mineral 42: $1601-1627$

SCHINDLER M, Hawthorne FC (2008) The stereochemistry and chemical composition of interstitial complexes in uranyl-oxysalt minerals. Canad Mineral 46: 467-501

Schindler M, Hawthorne FC, Baur WH (2000) A crystal chemical approach to the composition and occurrence of the vanadium minerals. Canad Mineral 38: 1443-1456

Schoep A (1932) La vandenbrandeite, un nouveau minéral uranifére. Ann Musée Congo Belge 1:24-31 (in French)

Shvareva TY, Fein JB, Navrotsky A (2012) Thermodynamic properties of uranyl minerals: constraints from calorimetry and solubility measurements. Ind Eng Chem Res 51: 607-613

SEJKORA J, ŠREIN V (2012) Supergene Cu mineralization from the Mědník hill near Měděnec, Krušné hory Mountains (Czech Republic). Bull mineral-petrolog Odd Nár Muz (Praha) 20: 255-269 (in Czech with English Abstract)

Sejkora J, Litochleb J, Bureš B, Jindra J (2004) New finds of supergene mineralization on the dump of the uranium mine no. 16, Př́ibram - Háje. Bull mineral-petrolog Odd Nár Muz (Praha) 12: 171-174 (in Czech)

Sejkora J, Ondruš P, Novák M (2010a) Veselovskýite, triclinic $(\mathrm{Zn}, \mathrm{Cu}, \mathrm{Co}) \mathrm{Cu}_{4}\left(\mathrm{AsO}_{4}\right)_{2}\left(\mathrm{AsO}_{3} \mathrm{OH}\right)_{2} .9 \mathrm{H}_{2} \mathrm{O}$, a $\mathrm{Zn}$-dominant analogue of lindackerite. Neu Jb Mineral, Abh 187: 83-90

SeJkora J, Plášil J, CísaŘová I, Hloušex J (2010b) Unusual fibrous mimetite from the Rovnost mine, Jáchymov
(St. Joachimsthal), Czech Republic. Acta MineralPetrogr, Abstract Series 6: 351

Sejkora J, Plášil J, Ondruš P, Veselovský F, Císařová I, HLOUŠEK J (2010c) Slavkovite, $\mathrm{Cu}_{13}\left(\mathrm{AsO}_{4}\right)_{6}\left(\mathrm{AsO}_{3} \mathrm{OH}\right)_{4} .23$ $\mathrm{H}_{2} \mathrm{O}$, a new mineral species from Horní Slavkov and Jáchymov, Czech Republic: description and crystal structure determination. Canad Mineral 48: 1157-1170

SejKora J, PlášIl J, Bureš B (2013) Unusual association of supergene uranium minerals from the Evangelista vein, Jáchymov (Czech Republic). Bull mineral-petrolog Odd Nár Muz (Praha) 21: 143-156 (in Czech with English abstract)

SHANNON RD (1976) Revised effective ionic radii and systematic studies of interatomic distances in halides and chalcogenides. Acta Cryst A32: 751-767

Sharpe R, Fayek M (2011) The world's oldest observed primary uraninite. Canad Mineral 49: 1199-1210

Š́kÁcha P, Goliáš V, Sejkora J, Pláššl J, Strnad L, ŠKoda R, JEŽEK J (2009) Hydrothermal uranium-base metal mineralization of the Jánská vein, Březové Hory, Př́bram, Czech Republic: lead isotopes and chemical dating of uraninite. J Geosci 54: 1-13

Šrein V, Langrová A (1999) Roscoelite from Jáchymov (Krušné hory Mts.). Bull mineral-petrolog Odd Nár Muz (Praha) 7: 214-215 (in Czech)

Steiger RH, JäGer E (1977) Subcommission on Geochronology: convention on the use of decay constants in geoand cosmochronology. Earth Planet Sci Lett 36: 359-362

ŠTĚP J, BECKE F (1904) Das Vorkommen des Uranpecherz zu St. Joachimsthal. Sitzungsber kais Akad Wiss, Mathnaturwiss K1 113: 585-618

Števko M, SejKora J, Plášil J (2012) Supergene uranium mineralization on the Banská Štiavnica deposit (Slovak Republic). Bull mineral-petrolog Odd Nár Muz (Praha) 20: 110-120 (in Slovak with English abstract)

Thoreau J, VAes JF (1932) La saléite, noveau minéral uranifère. Bull Soc Belg Geol 42: 96-100 (in French)

Trvala C (1962) Final report on geological situation during the closure of Rovnost and \#12 pits. Unpublished manuscript, DIAMO, pp 1-158

TVRDÝ J, PLÁšslL J (2010) Jáchymov - reiche Erzlagerstätte und Radonbad im böhmischen Westerzgebirge. Aufschluss 61: 277-292

VESELOVSKÝ F, ONDRUŠ P (2002) Secondary mineralization of Rožná uranium deposit and their comparison with the Jáchymov ore discrict. In: KŘíBEK B, ZeMAN J (eds) Uranium Deposits: From Their Genesis to Their Environmental Aspects. Czech Geological Survey, Prague, pp 121-124

Young RA (1993) The Rietveld Method. Oxford University Press, Oxford, U.K, pp 1-308.

Zittlau AH, Shi Q, Boerio-Goates J, Woodfield BF, MAJZLAN J (2013) Thermodynamics of the basic copper sulfates antlerite, posnjakite, and brochantite. Chem Erde 73: 39-50 